\title{
Three Essays On Tourism Demand And Economic Development In The United States
}

\author{
David Naab Aratuo \\ dnaratuo@mix.wvu.edu
}

Follow this and additional works at: https://researchrepository.wvu.edu/etd

Part of the Agricultural and Resource Economics Commons, and the Leisure Studies Commons

\section{Recommended Citation}

Aratuo, David Naab, "Three Essays On Tourism Demand And Economic Development In The United States" (2018). Graduate Theses, Dissertations, and Problem Reports. 3687.

https://researchrepository.wvu.edu/etd/3687

This Dissertation is protected by copyright and/or related rights. It has been brought to you by the The Research Repository @ WVU with permission from the rights-holder(s). You are free to use this Dissertation in any way that is permitted by the copyright and related rights legislation that applies to your use. For other uses you must obtain permission from the rights-holder(s) directly, unless additional rights are indicated by a Creative Commons license in the record and/ or on the work itself. This Dissertation has been accepted for inclusion in WVU Graduate Theses, Dissertations, and Problem Reports collection by an authorized administrator of The Research Repository @ WVU.

For more information, please contact researchrepository@mail.wvu.edu. 


\title{
Three Essays on Tourism Demand and Economic Development in the United States
}

\author{
David N. Aratuo
}

\author{
Dissertation Submitted to the \\ Davis College of Agriculture, Natural Resources and Design \\ West Virginia University \\ In partial fulfillment of the requirements for the degree of \\ Doctor of Philosophy \\ in \\ Natural Resource Economics \\ Peter Schaeffer, Ph.D., Co-Advisor
Xiaoli Etienne, Ph.D., Co-Advisor \\ Timothy Phipps, Ph.D. \\ Michael Dougherty, Ph.D. \\ Tesfa Gebremedhin, Ph.D.
}

Division of Resource Economics and Management

Morgantown, West Virginia

2018

Keywords: Tourism, Economic Growth, Granger Causality, Cointegration, Bounds test, Gravity Model, Pseudo Poisson Maximum Likelihood, Systems GMM

Copyright 2018 (David Naab Aratuo) 


\title{
ABSTRACT \\ Three Essays on Tourism Demand and Economic Growth in the United States
}

\begin{abstract}
David N. Aratuo
The global tourism industry has experienced sustained growth over the years even in the face of economic shocks. International travel for tourism purposes continues to grow albeit at different rates in developed and developing countries. The trend is suggestive of the significant impact of tourism on the global economy and social phenomena since the last century. A similar trend is observed in the United States as tourism contributes to the economy by generating revenues and creating jobs. The United States is a significant player in global tourism, being the largest exporter and the second largest importer of tourism. It is also the leading recipient of revenues from international tourists (ITA-NTTO, 2015). The growing relevance of tourism to economic development in the United States underscores the need to explore the nature of this relationship. This study, therefore, investigates the relationship between tourism demand and economic growth in three papers.

The first essay discusses the nature of the causal linkages between tourism and economic growth and how these respond to shocks in the system using the Autoregressive Distributed Lag model, the Impulse Response Function, and the Generalized Variance Decomposition respectively. The second essay investigates the economic growth and disaggregated tourism industries including accommodation, air transportation, shopping, food and beverage, other transportation, and recreation and entertainment. The paper employed the ARDL Bounds test and the Toda-Yamamoto Augmented Granger causality test to determine the direction of causality. In the third essay, I use a variety of econometric methods within the gravity model framework to highlight the static and dynamic determinants of inbound tourism to the United States. The findings from these essays confirm the economic-driven tourism growth (EDTG) hypothesis when aggregate tourism data is used. When disaggregated, the results show causality running from economic growth to each of the six tourism sub-industries. The results also emphasize the importance of some push and pull factors that influence U.S. tourism demand. The gravity variable such as incomes of the origin and destination countries and distance are significant determinants of inbound tourism to the U.S. Other economic, demographic, cultural, government policies, and incidental factors have a significant influence on tourism demand. The study further confirms the Linder hypothesis in the U.S. tourism literature and observe that habit persistence and/or word-ofmouth drive foreign visit to the United States.
\end{abstract}




\section{ACKNOWLEDGMENT}

I would like to acknowledge and thank the Almighty God whose goodness and favor has seen me through my graduate studies. I am cognizant of the many whose contributions and support helped in completing this work.

My sincere appreciation and gratitude to Dr. Dennis Smith (Professor Emeritus of Resource Economics and Management) who granted me my first tuition waiver, without which this journey would have been a mirage. I am very much thankful to my committee members; Dr. Peter Schaeffer, Dr. Xiaoli Etienne, Dr. Timothy Phips, Dr. Michael Dougherty, and Dr. Tesfa Gebremedhin, for their suggestions, direction, encouragement, and wise counsel without which this dissertation would not have seen the light of day. I am particularly indebted to Dr. Tesfa Gebremedhin who went beyond and above being an advisor to a father like figure. Special mention is also made of Dr. Xiaoli Etienne for her support and contributions throughout the process.

My gratitude and sincere thanks to my family for their physical, financial and spiritual support throughout this process. I would also like to acknowledge the support of the Division of Diversity and Inclusion and the Division of Resource Economics and Management towards the completion of this dissertation. Finally, I wish to acknowledge Dr. David Fryson, who has been a source of inspiration for the minority community at West Virginia University. 


\section{TABLE OF CONTENTS}

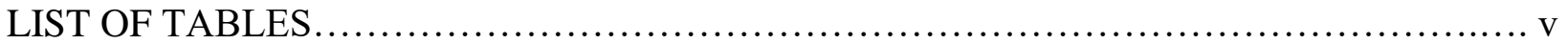

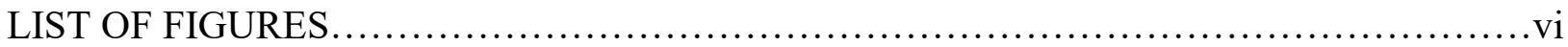

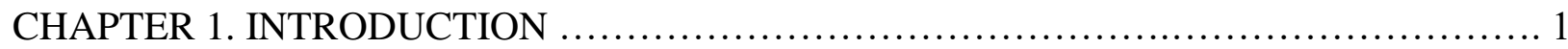

CHAPTER 2. REVISITING THE TOURISM-ECONOMIC GROWTH NEXUS: EVIDENCE

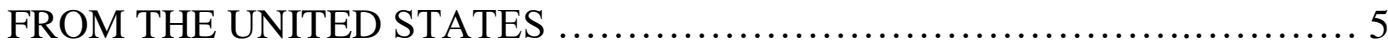

CHAPTER 3. INDUSTRY LEVEL ANALYSIS OF TOURISM-ECONOMIC GROWTH IN

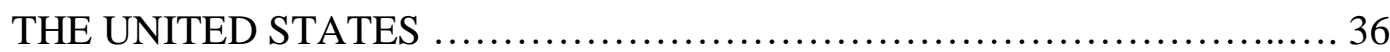

CHAPTER 4. AUGMENTED GRAVITY MODELLING OF INTERNATIONAL TOURISM DEMAND IN THE UNITED .........................................66

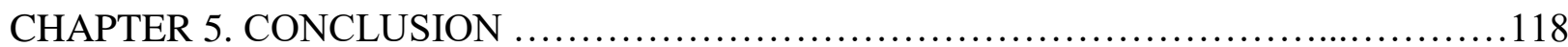




\section{LIST OF TABLES}

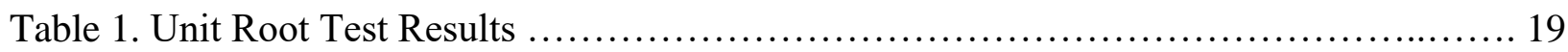

Table 2. ARDL Model Estimation and Bound Test Results ..................................21

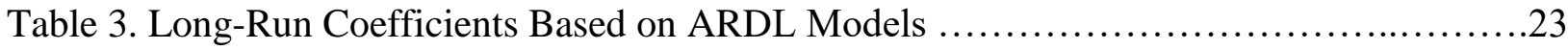

Table 4: Results of Granger Causality Test Based on ARDL Models ..........................24

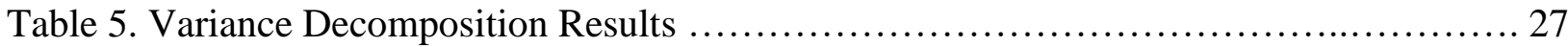

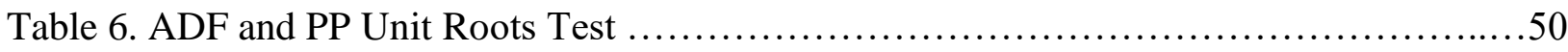

Table 7. Bivariate Bounds Test of Cointegration between tourism industries and GDP .........51

Table 8. Toda-Yamamoto Bivariate Granger Causality Test (GDP - Tourism Industries) .......53

Table 9. Bivariate Bounds Test of Cointegration between tourism industries ...................55

Table 10. Toda-Yamamoto Bivariate Granger Causality Test (Tourism Industries) ............. 56

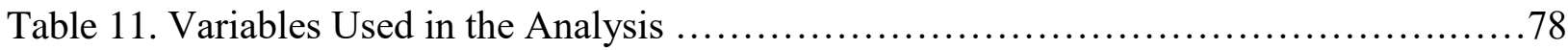

Table 12. Summary Statistics of Core Variables used in Analysis ............................. 85

Table 13. Basic and Augmented Gravity Model with Economic, Incidental Factors and Government Policy ........................................................ 87

Table 14. Augmented Gravity Model with Economic, Cultural Factors and Linder Effects ..... 90

Table 15. Augmented Gravity Model with Demographic and Cultural Factors.................... 91

Table 16. Augmented Gravity Model with Capital Investment and Terrorist Attack.............. 92

Table 17. Augmented Gravity Model with Governance Indicators............................. 95

Table 18. Augmented Gravity Model with Capital Investment and Linder effects..................97

Table 19. Estimation Results of Systems GMM Dynamic Model ...............................99

Table A1. Estimated Results of Pooled, Fixed and Random Effects .........................115

Table A2. Diagnostic Test on Fixed Effect Model ..........................................115

Table A3. Correlation Matrix of Basic Model ..............................................116

Table A4. Correlation Matrix of Economic Factors .......................................116

Table A5. Correlation Matrix of Demographic Factors .....................................116

Table A6. Correlation Matrix of Incidental Factors and Government Policies ..................116

Table A7. Correlation Matrix of Cultural Factors ….....................................117

Table A8. Correlation Matrix of Governance Indicators ..................................117 


\section{LIST OF FIGURES}

Figure 1. Plots of Real GDP, Tourist Arrivals, and Real Effective Exchange Rates of the United States, January 1996 - March 2016 ..........................................17

Figure 2. Responses of Tourist Arrivals to Various Shocks ................................26

Figure 3. Quarterly Real Tourist Spreading by Industries and the Real Gross Domestic Products of the U.S. (Seasonally Adjusted Annual Rates), 1998Q1 - 2017Q3 ................45

Figure 4. Graphical Representation of Granger Causality between the Tourism-Related Sub-

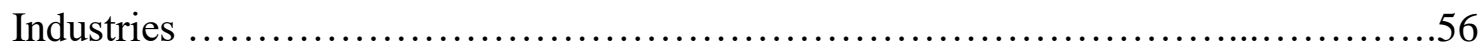

Figure 5. International Visitors and Spending in the United States (1999-2015) ...............67 


\section{CHAPTER 1. INTRODUCTION}

Tourism involves all activities engaged in by people traveling to and staying in places other than their original environment, for the purposes of leisure, business, and other related issues, for a period not more than one year (UN/WTO, 1994). It has been defined "broadly to include spending by visitors whose primary travel purposes are business, convention or conference travel, government business, and the more familiar travel for leisure, vacation or to visit friends and relatives" (IBIS World, 2015). The tourism industry has created a supply chain that benefits from the expenditure of the demand sector of the industry. The former includes among others: transportation (road and air- both domestic and international), accommodation services (hotels/motels, bed and breakfast, Airbnb, camping, friend or family house), food services, drinking places (restaurants), automotive, and travel \& tour services (Ibid), retail shopping, casino's/gambling (lottery games). Other tourism services include museums/art galleries, cultural and heritage sites, recreational parks, amusement/theme parks, national parks/monuments/ and other endowments of nature and historical locations. Sports and religious pilgrimage have also been sources of tourist attraction, and in recent times, specialized services provided by health and academic institutions known as medical and academic tourism.

The tourism industry is an important sector of the global economy because of its resilience and continued growth even in times of economic downturns (Marrocu et al., 2015). As a rapidly growing sector, it portends economic and social benefits to host countries. The tourism industry helps promote economic growth via job creation, infrastructure development, and foreign investment (Ertugrul and Mangir, 2015). The United States is a leading beneficiary of global tourism as one of the most visited destinations by foreigners and the highest recipient of tourism revenues. According to the United States Department of Commerce, international travel is the 
single largest services sector export in the United States. It accounts for $31 \%$ of all US service export; represents 9\% of all goods and services exports; generates more than $\$ 74$ billion of travel trade surplus and supports 1.1 million US jobs. Furthermore, one new job is created for every 67 international visitors to the United States and the industry generates more than $\$ 220$ billion in total employee compensation annually (OTTI-ITA, 2014). Against the backdrop of the growing importance of tourism in the United States, this study seeks to examine the relationship between the demand for tourism and economic growth in the United States in three papers.

In the first essay, the causal linkages between tourism and economic growth in the United States are assessed using the Autoregressive Distributed Lag (ARDL) model within the Vector Autoregressive (VAR) framework. The results confirm the economic-driven tourism growth hypothesis suggesting that economic growth Granger causes tourist arrivals in the United States in the long run, but, real effective exchange rate Granger causes tourist arrivals in both short and long runs. From the impulse response function and error variance decomposition, we find that shock to GDP generates a positive and significant effect on tourist arrivals into the United States that persist in the long run, while the effect from shocks to exchange rates occur for six months.

The tourism industry in the United States is not homogenous. Although the industry consists of several sub-industries, each providing different goods and services, the literature has used aggregate data in investigating the relationship between tourism and economic growth. Aggregate analyses obscure the individual sub-industry contribution to the economy. The second essay examines the tourism-economic growth relationship using disaggregated six tourism subindustries - accommodation, air transportation, shopping, food and beverage, other transportation, and recreation and entertainment. Employing the Augmented Toda-Yamamoto Granger causality within the Vector Autocorrelation framework, we observe unidirectional Granger causality 
running from economic growth to all six sub-industries. No long-run relationship, however, exists between the sub-industries and economic growth except for lodging and the food and beverage sectors. The results further show that causality predominantly flows from industries providing local offerings - food, entertainment, shopping, to those delivering destination goods and services.

The United States is the destination of choice for global long-haul travel. The number of international tourist arrivals and spending has been trending upwards and is projected to continue to grow. Advanced economies have been losing market share of tourist arrivals to emerging economies since 1995 (ITA-NTTO, 2015). The aggressive competition for tourists on the global market triggered a response from the United States Congress in passing legislation to make the United States more competitive and attract international tourists. The third essay investigates the drivers of inbound tourism to the United States using the Poisson Pseudo Maximum Likelihood estimation technique and the systems Generalized Methods of Moments within the gravity model framework. The results suggest that economic, and some cultural, demographic, institutional/governance, and incidental factors significantly influence tourism demand in the United States. The dynamic model indicates that habit persistence explains increasing tourism demand in the United States. Furthermore, the study confirmed the Linder hypothesis in the U.S. tourism literature. 


\section{References}

Ertugrul, H.M, and Mangir, F. (2015). 'The Tourism-led growth hypothesis: empirical evidence from Turkey.' Current Issues in Tourism, 18(7): 633-646.

IBIS World. (2015). IBISWorld Industry report NN002: Tourism in the US. http://clients1.ibisworld.com/reports/us/industry/default.aspx?entid=2002.

International Trade Administration, National Travel and Tourism Office, (2015). Fast facts: United States Travel and Tourism industry. 〈http://tinet.ita.doc.gov/outreachpages/download data table/Fast Facts 2015.pdf>.

International Trade Administration, National Travel and Tourism Office, (2015). Travel Promotion Act - Detailed summary of key points. <http://travel.trade.gov/about/Detailed_Summary.html >.

Marrocu, E., Paci, R., and Zara, A. (2015). 'Micro-economic determinants of tourist expenditure: a quantile regression approach'. Tourism Management, 50: 13-30.

UNWTO (2014). UNWTO Annual Report 2014. 


\title{
CHAPTER 2. REVISITING THE TOURISM-ECONOMIC GROWTH NEXUS: EVIDENCE FROM THE UNITED STATES
}

\begin{abstract}
This chapter assesses the short-run, long-run, and overall causal linkages between tourism and economic growth in the United States. Using monthly data from January 1996 to March 2016, we find that real GDP, a proxy for economic growth, Granger causes tourist arrivals into the United States in the long-run but not in the short-run. Tourist arrivals, on the other hand, do not cause GDP growth in either the short- or long-run. Overall, our findings appear to confirm the economicdriven tourism growth hypothesis, a proposition more likely to hold in developed economies. We also find that real effective exchange rates Granger cause tourist arrivals to the United States in both the short- and long-run. Additionally, a shock to GDP generates a positive and significant effect on tourist arrivals into the U.S. that persists in the long-run, while exchange rate shocks only have a significant effect in the first six months. In the short-run, exchange rate changes account for a larger share of the forecast error variance in tourist arrivals than GDP growth.
\end{abstract}

KEYWORDS: tourism, economic growth, GDP, tourist arrivals, real effective exchange rate, Granger causality 


\section{Introduction}

Tourism has gained widespread attention in recent years due to its potential contribution to the global economy. As one of the most rapidly growing sectors in the world, it contributes to economic growth by creating jobs, generating additional revenue streams, and enhancing technology and information transfer across-borders (Ertugrul and Mangir, 2015). For developing countries, it also provides the impetus for infrastructure improvement and serves as an important source of foreign exchange earnings necessary for capital, consumer, and intermediate goods imports (Oh, 2005; Phiri, 2015). The United States is an important player in the global tourism industry. In 2016, approximately 75.6 million international tourists visited the U.S., the second most in the world after France (UNWTO barometer, 2017), which generated about \$205.9 billion revenues from international tourists, the most among all countries (Ibid, 2017).

The tourism industry is increasingly playing an important role in the U.S. economy. According to the United Nations, in 2016 the tourism industry accounted for $31 \%$ of all U.S. service exports and $9 \%$ of all goods and services exports, generated more than $\$ 74$ billion in travelrelated surplus, and supported 1.1 million jobs. On average, for every 67 international visitors to the United States, one direct new job is created, and an additional 0.43 indirect job is generated (Bureau of Economic Analysis, 2015). The industry is also estimated to produce over $\$ 220$ billion total employee compensations annually (International Travel Administration, 2014).

An extensive literature has investigated the relationship between tourism and economic growth for various countries, often finding the relationship to vary depending on the specific country examined and time periods considered (e.g., Chou 2013; Aslan, 2014). Despite the importance of tourism in the U.S. economy and the U.S.' status as a leading international tourist destination and revenue recipient, research on the relationship between tourism and economic growth in the U.S. is surprisingly scanty. The only exception is Tang and Jang (2009), who 
investigated the relationship between the performance of several tourism-related industries and the Gross Domestic Product (GDP) in the United States. They found that there exists a unidirectional causality running from economic growth to tourism industry performance in the short-run, though no relationship between the two variables exists in the long-run.

The purpose of this study is to assess the short-run, long-run, and overall causal linkages between tourism and economic growth in the United States. Knowledge of such relationship is of pertinent interest not only to market participants in the tourist industry but also to policymakers wishing to assess the broader role of tourism in the overall economic growth and design policies for sustainable tourism development. To accomplish this goal, we use time series methods, in particular, the bound test of Pesaran et al., (2001) and the autoregressive distributed lag (ARDL) model, to test the causal relationship between international tourist arrivals into the United States. and its economic growth from 1996 to 2016. Since exchange rate fluctuations affect the affordability of the United States for international travelers and more broadly, the competitive position of United States tradable sectors, we include the real exchange rates of U.S. dollars in the analysis to account for the impact of currency value changes. In testing the causal linkages between the three variables, we rely on Granger causality, i.e., whether the lagged explanatory variables help to predict the current value of the dependent variable. We further use the generalized forecast error variance decompositions (VD) and impulse response functions (IRF) to evaluate the dynamic interactions between tourist arrivals and GDP growth.

The results suggest that real GDP in the U.S., a proxy for economic growth, Granger causes tourist arrivals in the long-run but not in the short-run. Real effective exchange rate, on the other hand, Granger causes tourist arrivals to the United States in both the short- and long-run. Tourist arrivals, on the other hand, do not cause GDP growth in either the short- or long-run. Overall, our 
findings appear to confirm the economic-driven tourism growth or the conversation hypothesis, a proposition more likely to hold in developed economies (Antonakakis et al., 2013; Tugcu, 2014; Phiri, 2015). We also find that real effective exchange rates Granger cause tourist arrivals to the United States in both the short- and long-run. Additionally, a shock to GDP generates a positive and significant effect on tourist arrivals into the U.S. that persists in the long-run, while exchange rate shocks only have a significant effect in the first six months. In the short-run, exchange rate changes account for a larger share of the forecast error variance in tourist arrivals than GDP growth.

The rest of the paper is structured as follows. The second section reviews the theoretical links between economic growth and tourism, as well as the empirical literature investigating such relationship. Sections three and four describe the empirical methodology and data, respectively. Section five presents the empirical results. Conclusions are provided in section six.

\section{A Brief Review of Literature}

The theoretical evidence on the relationship between the tourism sector and economic growth is well-documented. One stream of literature explores the long-run relationship between the two using either endogenous or exogenous growth models (Hazari and Sgrò, 1995; Lanza and Pigliaru, 1995, 2000; Candela and Cellini, 1997; Lozano et al., 2008). This literature represents the tourism-led economic growth hypothesis (Panagiotidis et al., 2012) which argues that a unidirectional causality is running from tourism to economic growth. This hypothesis views international tourism as a strategic factor for long-run economic growth (Shan and Wilson, 2001), generating direct, indirect, or induced effect on other productive sectors of the economy (Tugcu, 2014). Specifically, tourism positively affects the destination country by (i) generating foreign exchange revenue that can be invested in productive sectors, (ii) encouraging competition and 
investment in infrastructure, (iii) stimulating the growth of travel-related industries, (iv) creating additional income and employment, (v) reducing local production cost via economies of scale, and (vi) providing a means by which technical knowledge can be diffused, research assimilated, and human capital transferred (Androitis, 2002; Brida, Carrera, and Risso, 2008; Brida, CortesJimenez and Pulina, 2016; Croes, 2006; McKinnon,1964). A direct implication of the tourism-led growth hypothesis is that policies subsidizing tourism may contribute positively to drive economic growth (Tugcu, 2014).

Contrary to the tourism-led economic growth hypothesis, the second stream of literature asserts that economic fluctuations are the driving force behind the tourism sector. This is often referred to as the economic-driven tourism growth hypothesis or the conservation hypothesis (Antonakakis et al., 2013; Tugcu, 2014; Phiri, 2015). The reasoning underpinning this assertion is that resource availability, infrastructure development, and political stability create an ambient economic climate that promotes tourism activities. In order to attract more tourists to a country, policymakers should focus on improving economic growth, which will be transferred to the tourist industry as improved infrastructure and tourism-related services (Phiri, 2015). Under the economic-driven tourism growth hypothesis, highly industrialized countries have a growing tourism industry because of their stronger economies as compared to developing economies (Lanza et al., 2003).

A third hypothesis, termed the feedback or reciprocal hypothesis, argues that there exists a bi-directional feedback relationship between tourism and economic growth (Phiri, 2015; Tugcu, 2014; Antonakakis et al., 2015). Such a hypothesis calls for policies simultaneously promoting tourism and economic growth (Phiri, 2015). Some researchers have also advocated for a fourth hypothesis, known as the no causality hypothesis that denies the existence of any relationships 
between tourism and economic growth. (Antonakakis et al., 2013; Tugcu, 2014; Antonakakis et al., 2015; Phiri, 2015).

Various studies have empirically investigated the linkages between tourism and economic growth, often finding conflicting results depending on the countries and time periods considered (Aslan, 2014). Using Johansen's cointegration and Granger causality tests, Balaguer and Cantavella-Jorda (2002) found a unidirectional causality running from tourism to economic growth in Spain, thus providing strong evidence in favor of the tourism-led growth hypothesis. Similar findings were discussed in Brida et al., (2010), who found a positive effect of tourism expenditure on GDP per capita in Uruguay. Examining tourism receipts, tourism arrivals, exchange rates, and GDP for seven countries in the Mediterranean, Dritsakis (2012) affirmed the impact of tourism on economic growth. Similar results observed in several other studies, including Lanza, Templec, and Urga (2003) for 13 OECD (Organization for Economic Co-operation and Development) countries, Durbarry (2004) for Mauritius, Gunduz and Hatemi (2005), and Zortuk (2009) for Turkey, Proenca and Soukiazis (2008) for several southern European countries, Brida and Risso (2010) for South Africa, Belloumi (2010) for Tunisia (Africa), and Katircioglu (2010) for Singapore, among others.

Some studies show evidence supporting the economic-driven tourism growth hypothesis. Using the Engle and Granger two-stage approach and bivariate Vector Autoregressive (VAR) model, Oh (2005) observed that while no cointegration (i.e., long-run equilibrium) exists between tourism and economic growth, economic growth Granger-causes tourism in South Korea but not vice versa in the short-run. Tang and Jang (2009) analyzed the relationship between the performance of four tourism industries (airlines, casinos, hotels, and restaurants) and GDP using Johansen cointegration and Granger causality tests in the United States. Their results show that 
while no long-run relationship exists between economic growth and tourism industry performance, there is a unidirectional causality running from GDP to tourism industry performance in the United States. Empirical analyses by Lee and Chien (2008), Payne and Mervar (2010), and Odhiambo (2011) provide further evidence in support of the economic-driven tourism growth hypothesis in various other countries.

Regarding the third hypothesis, Dritsakis (2004) found tourism, economic growth, and real exchange rates to be cointegrated, and a reciprocal causal relationship exists between tourism and economic growth in Greece from 1960-2000. Similar findings were obtained for Taiwan by Kim et al. (2006) and Lee and Chien (2008) and for Malaysia by Tang (2011a, 2011b). On the contrary, Jackman and Lorde (2010) and Katircioglu (2009) indicate no causal relationship between tourism and economic growth in Barbados and Turkey, respectively.

Currently, the United States is the leading importer (outbound tourism) of global tourism, and the world's second-largest exporter of tourism (inbound tourism). Despite its significance in the US economy, no empirical work exists on the tourism-economy relationship in the United States beyond the sub-industry level as analyzed by Tang and Jang (2009), and recently by Yadzi and Khanalizadeh (2017). Additionally, no empirical work in this area, as far as the authors are concerned, has accounted for the nature of interactions between economic growth and tourism due to innovations originated from one variable. Knowledge of such information often proves useful when assessing how the tourist industry responds to unexpected shocks in the economy brought about by policy or other exogenous changes over time, as well as how unexpected changes in the tourist industry affect the overall economic growth. In the present paper, we seek to fill in this important gap in the literature by jointly considering the relationship between tourist arrivals, GDP growth, and real exchange rates, and the nuances of their interactions in the United States. 


\section{Empirical Methodology}

As with most empirical analysis, we would like to include as many determinants of the dependent variable as possible. However, due to data limitations we may only include the most important variables in the empirical model. Here, we use international tourist arrivals (TA) into the U.S. as a proxy for the country's tourism industry development, and the real GDP (RGDP) as an indicator of economic growth. Additionally, we consider the real effective exchange rate (REER) of United States dollars, i.e., the weighted average of US dollars relative to a basket of other major currencies after adjusting for relative consumer prices. Real effective exchange rate should partially capture the relative prices tourist will pay at the host country compared to other destinations, and changes in REER should indicate how travel cost varies due to either currency value fluctuations or relative price movement. Previous studies report evidence that the exchange rate significantly affects a country's competitiveness and attractiveness as a tourist destination since it ties directly to the cost of traveling (Oh, 2005; Gunduz and Hatemi-J, 2005; Balaguer and Cantavella-Jorda, 2002). A rise in the real effective exchange rate may be due to higher inflation in the destination country, or an appreciation of the country's currency relative to other destinations. In both scenarios, the U.S. becomes a less attractive tourist destination. We model tourist arrivals into the U.S. as in equation (1):

$$
\ln T A_{t}=a+b \ln R G D P_{t}+\operatorname{cln} R E E R_{t}+\epsilon_{t}
$$

where $a, b$ and $c$ are coefficients to be estimated and $\epsilon_{t}$ is a stationary process representing the error term. As discussed earlier, a higher U.S. dollar exchange rate will make the U.S. a less attractive tourist destination, hence a negative sign is expected for $c$. With a higher GDP, a country may be able to increase its investment in tourist marketing, infrastructure development, and travelrelated services, which should make the country a more attractive tourist destination for international travelers. However, with a higher GDP, traveling within the country may become 
costlier due to a higher labor cost often observed in developed countries, making the country a less cost competitive tourist destination. Therefore, the exact sign of $b$ depends on the relative strength of these two effects.

Equation (1) is often referred to as the long-run relationship between the three variables, where the coefficients associated with the real GDP and effective exchange rates indicate the longrun effect of these two exogenous variables to tourist arrivals. To estimate the short-run effect, we follow Pesaran et al.'s (2001) bound test and construct the following autoregressive distributed lag (ARDL) model of order $(p, q, l)$ :

$$
\begin{aligned}
\Delta \ln T A_{t}=\beta_{0} & +\beta_{1} \ln T A_{t-1}+\beta_{2} \ln G D P_{t-1}+\beta_{3} \ln R E E R_{t-1}+\sum_{i=1}^{p} \alpha_{i} \Delta \ln T A_{t-i} \\
& +\sum_{j=0}^{q} \phi_{j} \Delta \ln G D P_{t-j}+\sum_{k=0}^{l} \tau_{k} \Delta \ln R E E R_{t-k} .
\end{aligned}
$$

In the equation, $\Delta$ is the first difference operator, $t$ is the time period, and $\alpha \mathrm{s}, \beta \mathrm{s}, \phi \mathrm{s}$, and $\tau \mathrm{s}$ are the parameters. Compared to the conventional error correction model of Engel and Granger (1987) which restricts the error correction term (a linear combination between lagged dependent and independent variables) to follow the long-run relationship ${ }^{1}$, the ARDL model does not restrain the coefficients of the lagged level variables. Indeed, the ARDL specification is often termed "unrestricted ECM," or "conditional ECM" as in Pesaran et al. (2011).

Pesaran et al., (2001) suggest that equation (2) can be used to test for the cointegrating (long-run) relationship between the variables involved in the model by jointly testing the statistical

\footnotetext{
${ }^{1}$ For instance, the conventional error correction model for equation (2) can be written as:

$$
\Delta \ln T A_{t}=\beta_{0}+\beta_{1} E C T_{t-1}+\sum_{i=1}^{p} \alpha_{i} \Delta \ln T A_{t-i}+\sum_{j=0}^{q} \phi_{j} \Delta \ln G D P_{t-j}+\sum_{k=0}^{l} \tau_{k} \Delta \ln R E E R_{t-k} .
$$

where $E C T_{t-1}=\ln T A_{t-1}+\theta_{1} \operatorname{lnGDP_{t-1}}+\theta_{2} \ln R E E R_{t-1}$ is the error correction term.
} 
significance of the lagged level variables, i.e., $H_{0}: \beta_{1}=\beta_{2}=\beta_{3}=0$. One caveat with the bound test is that when testing the null hypothesis of no cointegration, alternative critical values should be used instead of the conventional F-stat critical values. These critical values are reported in Pesaran and Shin (1999) and Pesaran et al., (2001). No cointegrating relationship exists between the three variables if the $\mathrm{F}$ statistics falls below the lower critical bounds value $\left(F<F^{L}\right)$, while cointegration exist when the $\mathrm{F}$ statistics exceeds the upper critical bounds value $\left(F>F^{U}\right)$. The cointegration test is however inconclusive when the F statistics exceeds the lower critical bound value but falls below the upper critical bound value $\left(F^{L}<F<F^{U}\right)$.

Compared to the conventional Johansen cointegration test, the ARDL bounds test is appealing because it does not require all variables to be integrated of the same order, it is relatively more efficient in small and finite samples, and it is robust to serial correlation and reverse causality (Pesaran et al., 2001; Narayan and Narayan, 2004; Harris and Sollis, 2003). Moreover, different lags can be specified for the regressors in the ARDL model, while the vector error correction model requires that the same order of lag length be used for all variables. One requirement for the ARDL bound test, however, is that all variables are not integrated of order two, or I(2). This assumption can be tested by applying the conventional unit root tests to the first-differenced variables.

If the three variables are found to be cointegrated, then we can recover this long-run relationship by normalizing the estimates of the lagged level variables in equation (2) that represents the error correction component. Specifically, we set:

$$
0=\beta_{1} \ln T A_{t-1}+\beta_{2} \ln G D P_{t-1}+\beta_{3} \ln R E E R_{t-1}+v_{t} .
$$

Solving for $\ln T A_{t-1}$, we have

$$
\ln T A_{t-1}=-\frac{\beta_{2}}{\beta_{1}} \ln G D P_{t-1}-\frac{\beta_{3}}{\beta_{1}} \ln R E E R_{t-1}+\epsilon_{t}
$$


Comparing the normalized long-run relationship in equation (4) with equation (1), we can recover the long-run coefficients between tourist arrivals, GDP, and exchange rate using the ARDL model in equation (2) by setting $b=-\frac{\beta_{2}}{\beta_{1}}$ and $c=-\frac{\beta_{3}}{\beta_{1}}$. We hence obtain:

$$
\begin{aligned}
\Delta \ln T A_{t}=\beta_{0}+ & \beta_{1}\left(\ln T A_{t-1}+\frac{\beta_{2}}{\beta_{1}} \ln G D P_{t-1}+\frac{\beta_{3}}{\beta_{1}} \ln R E E R_{t-1}\right)+\sum_{i=1}^{p} \alpha_{i} \Delta \ln T A_{t-i} \\
& +\sum_{j=0}^{q} \phi_{j} \Delta \ln G D P_{t-j}+\sum_{k=1}^{l} \tau_{k} \Delta \ln T A_{t-k}
\end{aligned}
$$

According to Peseran et al. (2001), equation (5) incorporates the conditional long-run relationship between the three variables, where $-\frac{\beta_{2}}{\beta_{1}}$ and $-\frac{\beta_{2}}{\beta_{1}}$ represent the conditional long-run multipliers. Additionally, $\beta_{1}$ can be considered as the counterparts of the adjustment coefficient in an error correction model, indicating the speed of adjustment by tourist arrivals to the long-run equilibrium if deviations occur.

To test the long-run, short-run, and overall causality from GDP growth and exchange rates to tourist arrivals in the U.S., we specify the following null hypotheses:

Long-run causality from GDP and exchange rates to TA: $\beta_{1}=0$

Short-run causality from GDP to TA: $\phi_{0}=\phi_{1}=\cdots=\phi_{q}=0$

Overall causality from GDP to TA: $\beta_{1}=\phi_{0}=\phi_{1}=\cdots=\phi_{q}=0$

Short-run causality from REER to TA: $\tau_{0}=\tau_{1}=\cdots=\tau_{k}=0$

Overall causality from REER to TA: $\beta_{1}=\tau_{0}=\tau_{1}=\cdots=\tau_{k}=0$

Since we are interested in the bi-directional relationships between GDP and tourist arrivals, we follow a similar step as described for tourist arrivals and estimate the following equation for GDP: 


$$
\begin{aligned}
\Delta \ln G D P_{t}=\beta_{0}^{G} & +\beta_{1}^{G}\left(\ln T A_{t-1}+\frac{\beta_{2}^{G}}{\beta_{1}^{G}} \ln G D P_{t-1}+\frac{\beta_{3}^{G}}{\beta_{1}^{G}} \ln R E E R_{t-1}\right) \\
& +\sum_{i=1}^{p} \alpha_{i}^{G} \Delta \ln T A_{t-i}+\sum_{j=0}^{q} \phi_{j}^{G} \Delta \ln G D P_{t-j}+\sum_{k=1}^{l} \tau_{k}^{G} \Delta \ln T A_{t-k}
\end{aligned}
$$

The null hypotheses of long-run, short-run, and overall causality from tourist arrivals to the U.S. and exchange rates to GDP growth are:

Long-run causality from TA and exchange rates to GDP: $\beta_{1}^{G}=0$

Short-run causality from TA to GDP: $\alpha_{0}^{G}=\alpha_{1}^{G}=\cdots \alpha_{q}^{G}=0$

Overall causality from TA to GDP: $\beta_{1}^{G}=\alpha_{0}^{G}=\alpha_{1}^{G}=\cdots=\alpha_{q}^{G}=0$

Short-run causality from REER to GDP: $\tau_{0}^{G}=\tau_{1}^{G}=\cdots=\tau_{k}^{G}=0$

Overall causality from REER to GDP: $\beta_{1}^{G}=\tau_{0}^{G}=\tau_{1}^{G}=\cdots=\tau_{k}^{G}=0$

\section{Data}

Monthly data on real GDP in the U.S., international tourist arrivals to the U.S., and the real effective exchange rate of United States dollars for January 1996-March 2016 are used for our analysis. Data on international tourist arrivals were obtained from the National Travel and Tourism Office of the US Department of Commerce, and were used to measure the level of inbound tourist activity to the U.S. An alternative way to measure tourist activity commonly used in the literature is tourism receipts. However, these data are only available for a much shorter period. Data on real GDP, measured in billion dollars, were obtained from the Bureau of Economic Analysis and Macroadviser.com. The real effective exchange rate data, calculated as weighted averages of bilateral exchange rate adjusted by relative consumer price and indexed at 2010 dollars, were obtained from the Federal Reserve Bank of St. Louis. 
(a) Real GDP, in Billion Dollars

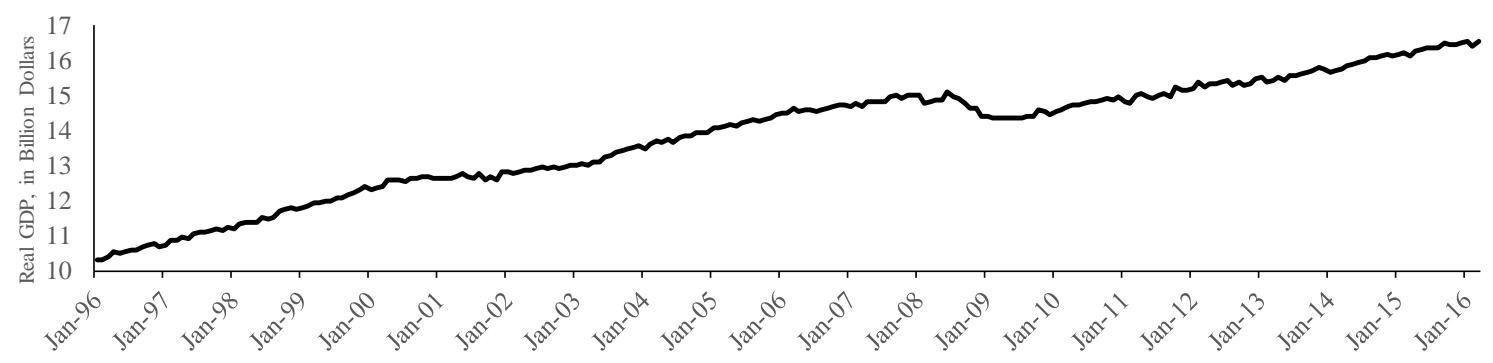

(b) Tourist Arrivals, in Million Visits

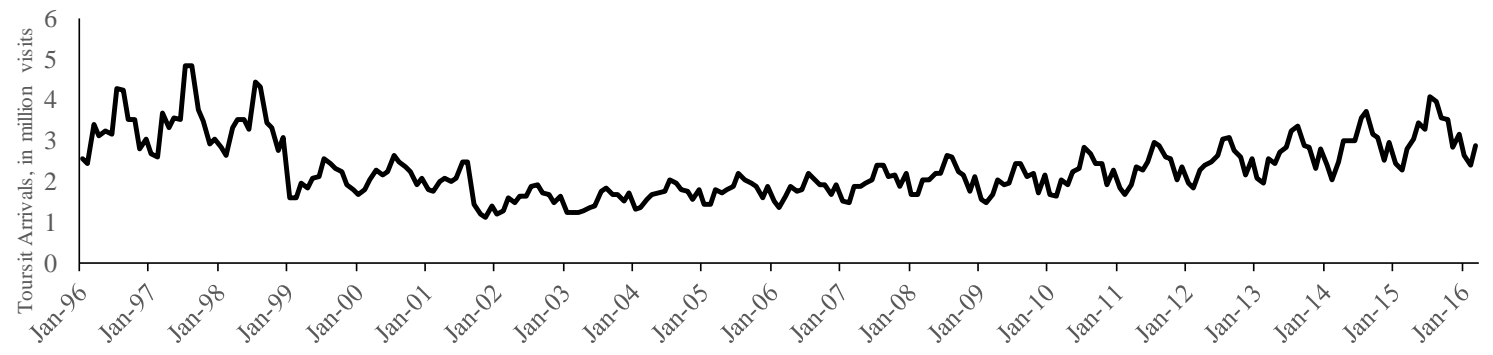

(c) Real Effective Exchange Rate, Index

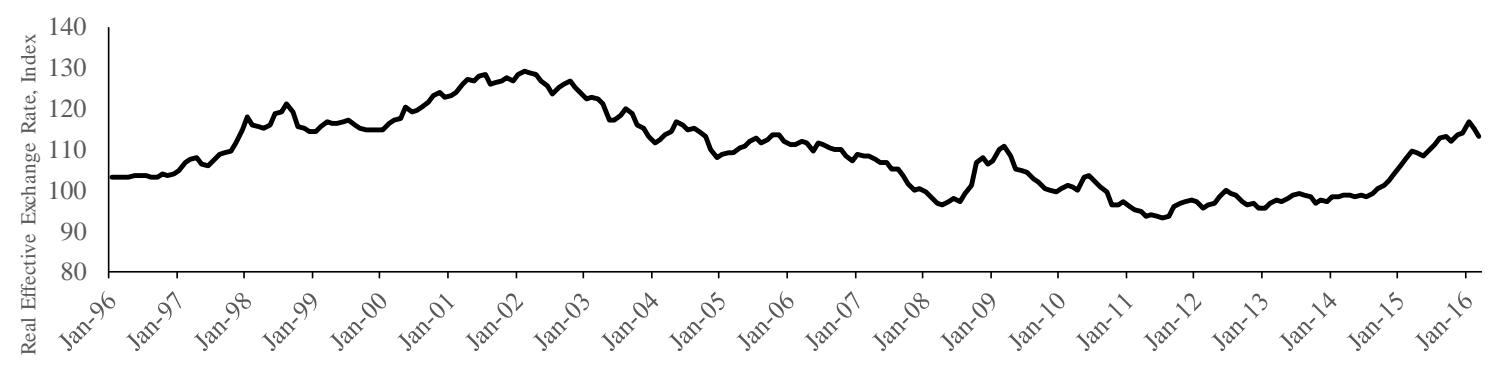

Figure 1. Plots of Real GDP, Tourist Arrivals, and Real Effective Exchange Rates of the United States, January 1996-March 2016

Figure 1 plots the three variables (in levels) considered in this study. The number of international tourists visiting the U.S. per month varies between 1 million and 5 million. On average, a total of 2.3 million tourists visited the United States per month over our sample period. Tourist arrivals to the U.S. appear to be highly seasonal, with a substantially larger number of visitors in the summer than in the winter. However, the difference between summer and winter arrivals appear to be smaller between 2002 and 2012 than other time periods during the sample.

Additionally, there exists a sharp decrease in tourist arrivals in January 1999, and again in the second half of 2001 (corresponding to the $9 / 11$ terrorist attack), after which the number of 
international tourist arrivals has been trending upwards. While it is hard to pinpoint precisly what caused the sharp decline in tourist arrivals between 1999 and 2000, several events that occurred at the end of the $20^{\text {th }}$ century, in particular, the financial crises in Asia and Russia, may have contributed to the decline of tourist visits to the United States. The coefficient of variation (standard deviation over mean) suggests that compared to GDP and exchange rate, tourist arrivals are significantly more volatile. Figure 1 also suggests that with a few exceptions, most notably the 2008-2009 financial crisis, real GDP in the U.S. trended upward during the sample period. On the other hand, the real effective exchange rate of US dollars exhibited both positive and negative trends. Most recently, United States dollars have appreciated significantly, reaching a level comparable to mid-2000s.

\section{Results}

As with most time series studies, all three variables are converted to their natural logarithms to reduce skewness and kurtosis. Additionally, the first difference of logarithmic values allows for the interpretation of relative effect in regression analysis. Though the bound test can be applied to variables that are either stationary or nonstationary, the test is inapplicable when any of the variables are integrated of order two. The first step of our empirical analysis, therefore, is to investigate the stationarity properties of the three variables. A nonstationary variable tends to have time-changing means and variances. Applying standard statistical procedures to nonstationary time series data may generate spurious results driven by trends or random walks. Here, we use several conventional unit roots tests, i.e., the Augmented Dickey-Fuller (ADF) test, the PhillipsPerron (PP) test, the Kwiatkowski, Phillips, Schmidt, and Shin (KPSS) test, and the Dickey-Fuller Generalized Least Square (DF-GLS) test to determine the stationarity of variables. Except for the 
KPSS test, the null hypothesis for all other test is that the series is non-stationary or containing a unit root. For the KPSS test, the null hypothesis is that the series is stationary.

Table 1. Unit Root Test Results

\begin{tabular}{llllll}
\hline Model & Variable & ADF & PP & KPSS & DF-GLS \\
\hline Intercept & $\operatorname{lnTA}$ & $-1.456(12)$ & $-3.859(4)^{* * *}$ & $0.453(11)^{*}$ & $-1.245(12)$ \\
& $\operatorname{lnRGDP}$ & $-3.399(1)^{* *}$ & $-3.173(4)^{* *}$ & $1.850(12)^{* * *}$ & $4.103(1)^{* * *}$ \\
& $\operatorname{lnREER}$ & $-1.598(1)$ & $-1.412(5)$ & $0.989(12)^{* * *}$ & $-1.320(1)$ \\
\hline Intercept & $\operatorname{lnTA}$ & $-1.608(12)$ & $-3.866(4)^{* *}$ & $0.442(11)^{* * *}$ & $-1.211(12)$ \\
and trend & $\operatorname{lnRGDP}$ & $-2.585(1)$ & $-2.462(3)$ & $0.391(12)^{* * *}$ & $-0.4226(1)$ \\
& $\operatorname{lnREER}$ & $-2.097(1)$ & $-1.803(5)$ & $0.236(11)^{* * *}$ & $-1.437(1)$ \\
\hline Intercept & $\Delta \operatorname{lnTA}$ & $-4.602(11)^{* * *}$ & $-18.372(0)^{* * *}$ & $0.0331(4)$ & $-1.700(11)^{*}$ \\
& $\Delta \operatorname{lnRGDP}$ & $20.415(0)^{* * *}$ & $-19.900(6)^{* * *}$ & $0.717(1)^{* *}$ & $-19.416(0)^{* * *}$ \\
& $\Delta \operatorname{lnREER}$ & $-10.669(0)^{* * *}$ & $-10.498(3)^{* * *}$ & $0.189(5)$ & $-10.611(0)^{* * *}$ \\
\hline Intercept & $\Delta \operatorname{lnTA}$ & $-5.066(11)^{* * *}$ & $-18.340(0)^{* * *}$ & $0.015(4)$ & $-2.370(11)$ \\
and trend & $\Delta \operatorname{lnRGDP}$ & $-20.889(0)^{* * *}$ & $-20.812(4)^{* * *}$ & $0.124(12)^{*}$ & $-19.272(0)^{* * *}$ \\
& $\Delta \operatorname{lnREER}$ & $-10.646(0)^{* * *}$ & $-10.474(3)^{* * *}$ & $0.188(5)^{* *}$ & $-10.521(0)^{* * *}$ \\
\hline
\end{tabular}

Notes: The numbers in the parenthesis are the lag length used for each test, as selected by the SBC. One, two, and three asterisks denote statistical significance at $10 \%, 5 \%$, and $1 \%$, respectively. The null of all tests except KPSS is that the series of interest in non-stationary. For the KPSS test, the null hypothesis is that the series is stationary.

Table 1 presents the unit root test results. For robustness, unit root tests both with and without a time trend are considered. As can be seen in the table, testing results for the level variables are mixed, depending on the statistical test employed and the specific regression model used. For instance, while the ADF, PP, and DF-GLS tests find the GDP to be stationary when the test equation includes an intercept but not a trend, the GDP is nonstationary in all tests with both intercept and a trend. Tourists arrivals are stationary in the PP test but nonstationary in all other tests. By contrast, with a few exceptions, we find all variables to be stationary at their firstdifferences. The mixed results from stationarity tests suggest that when investigating the long-run relationship between the three variables, the bounds test should be preferred over the Johansen cointegration or the Engle-Granger tests which require all variables to be integrated of order one, i.e., non-stationary in levels but stationary in first differences. 
Our next step is to examine whether there had been structural breaks that could affect the mean of tourist arrivals and GDP during the sample periods. Results from the Bai and Perron (1989) structural break test (results available on request) suggest that there existed two structural breaks in tourist arrivals to the U.S., one in January 1999, and the other in April 2011. Interestingly, despite the sharp decline in tourist arrivals after the 911 terrorist attack in 2001, the test did not

identify a structural break around that time. As discussed earlier, at the end of the $20^{\text {th }}$ century there was a sharp decline in tourist arrivals possibly due to the widespread financial crisis in Asia and Russia, which may have accounted for the structural break in January 1999. For the second structural break in April 2004, Figure 1 suggests that the number of tourist visits to the U.S. increased, possibly due to the continuing depreciation of the United States dollar which had made the U.S. a more affordable tourist destination. For the GDP, we also find one structural break that occurred in September 2003.

\subsection{The ARDL model and bound test of a long-run relationship}

Having determined the order of integration of the three variables and the structural breaks, we proceed to investigate the presence of long-run relationship among the three variables using the ARDL bound test as specified in equation (2). The structural breaks are included as shifts in the mean in the regression analysis, i.e., as dummy variables representing the periods separated by the breakpoints. The optimal lag length of the ARDL model is selected based on the Schwarz Bayesian Criteria (SBC), with additional lags added if autocorrelation is detected in the residuals.

Estimation results are presented in Table 2. For robustness, we present the estimation results for models both with and without exchange rates. With a few exceptions, diagnostic tests (panel C) for serial correlation and normality ascertain the goodness of fit of the estimated ARDL models. Residual homoscedasticity is also confirmed for most of the models. 
Table 2. ARDL Model Estimation and Bound Test Results

\begin{tabular}{|c|c|c|c|c|}
\hline Variables & $\begin{array}{l}\text { Model 1 } \\
\ln T A_{t}\end{array}$ & $\begin{array}{l}\text { Model 2 } \\
\ln T A_{t}\end{array}$ & $\begin{array}{l}\text { Model 3 } \\
\ln G D P_{t}\end{array}$ & $\begin{array}{l}\text { Model } 4 \\
\ln G D P_{t}\end{array}$ \\
\hline \multicolumn{5}{|l|}{ Panel A. Estimation Results } \\
\hline $\ln T A_{t-1}$ & $\begin{array}{l}-0.340 * * * \\
(0.055)\end{array}$ & $\begin{array}{l}-0.345^{* * *} \\
(0.053)\end{array}$ & $\begin{array}{l}0.002 \\
(0.001)\end{array}$ & $\begin{array}{l}0.001 \\
(0.001)\end{array}$ \\
\hline $\ln G D P_{t-1}$ & $\begin{array}{l}0.173 \\
(0.192)\end{array}$ & $\begin{array}{l}0.276^{*} \\
(0.147)\end{array}$ & $\begin{array}{l}-0.011^{*} \\
(0.006)\end{array}$ & $\begin{array}{l}-0.012 * * \\
(0.006)\end{array}$ \\
\hline $\ln R E E R_{t-1}$ & $\begin{array}{l}-0.176 \\
(0.145)\end{array}$ & & $\begin{array}{l}0.001 \\
(0.006)\end{array}$ & \\
\hline$\Delta \ln T A_{t}$ & & & $\begin{array}{l}0.004 \\
(0.002)\end{array}$ & $\begin{array}{l}0.004 \\
(0.002)\end{array}$ \\
\hline$\Delta \ln T A_{t-1}$ & $\begin{array}{l}-0.028 \\
(0.056)\end{array}$ & $\begin{array}{l}-0.011 \\
(0.066)\end{array}$ & $\begin{array}{l}0.005 * \\
(0.002)\end{array}$ & $\begin{array}{l}0.005^{* *} \\
(0.002)\end{array}$ \\
\hline$\Delta \ln T A_{t-2}$ & & $\begin{array}{l}0.074 \\
(0.063)\end{array}$ & & \\
\hline$\Delta \ln G D P_{t}$ & $\begin{array}{l}1.909 \\
(1.756)\end{array}$ & $\begin{array}{l}1.931 \\
(1.676)\end{array}$ & & \\
\hline$\Delta \ln G D P_{t-1}$ & $\begin{array}{l}2.436 \\
(1.956)\end{array}$ & $\begin{array}{l}1.919 \\
(1.674)\end{array}$ & $\begin{array}{l}-0.325 * * * \\
(0.062)\end{array}$ & $\begin{array}{l}-0.314 * * * \\
(0.061)\end{array}$ \\
\hline$\Delta \ln R E E R_{t}$ & $\begin{array}{l}-0.674 \\
(0.707)\end{array}$ & & $\begin{array}{l}-0.062 * * \\
(0.031)\end{array}$ & \\
\hline$\Delta \ln R E E R_{t-1}$ & $\begin{array}{l}2.021 * * \\
(0.889)\end{array}$ & & $\begin{array}{l}0.008 \\
(0.031)\end{array}$ & \\
\hline$D_{1}$ & $\begin{array}{l}-0.229 * * * \\
(0.068)\end{array}$ & $\begin{array}{l}-0.258 * * * \\
(0.054)\end{array}$ & & \\
\hline$D_{2}$ & $\begin{array}{l}-0.142 * * \\
(0.074)\end{array}$ & $\begin{array}{l}-0.159 * * \\
(0.062)\end{array}$ & & \\
\hline$D_{3}$ & & & $\begin{array}{l}0.001 \\
(0.002)\end{array}$ & $\begin{array}{l}0.001 \\
(0.001)\end{array}$ \\
\hline Constant & $\begin{array}{l}0.811 \\
(0.965)\end{array}$ & $\begin{array}{l}-0.258 \\
(0.352)\end{array}$ & $\begin{array}{l}0.025 \\
(0.031)\end{array}$ & $\begin{array}{l}0.033 * * \\
(0.014)\end{array}$ \\
\hline Observations & 241 & 241 & 241 & 241 \\
\hline R-squared & 0.222 & 0.197 & 0.160 & 0.144 \\
\hline \multicolumn{5}{|c|}{ Panel B. Bound Test for Cointegration } \\
\hline F. stat & 15.967 & 21.857 & 1.917 & 2.815 \\
\hline CV 95\%, lower bound & 3.79 & 4.94 & 3.79 & 4.94 \\
\hline CV 95\%, upper bound & 4.85 & 5.73 & 4.85 & 5.73 \\
\hline \multicolumn{5}{|c|}{ Panel C. Diagnostic Test Results (p-value) } \\
\hline DW for autocorrelation, lag 1 & 0.298 & 0.252 & 0.273 & 0.255 \\
\hline DW for autocorrelation, lag2 & 0.177 & 0.241 & 0.513 & 0.448 \\
\hline SW for normality & 0.132 & 0.197 & 0.052 & 0.070 \\
\hline $\mathrm{BP}$ for heteroscedasticity & 0.225 & 0.036 & 0.731 & 0.984 \\
\hline
\end{tabular}

Notes: for panel A, numbers in parenthesis are standard errors, and one, two, and three asterisks denote statistical significance at $10 \%, 5 \%$, and $1 \%$, respectively. DW=Durbin Watson autocorrelation test, SW=Shapiro-Wilk normality tests, and $\mathrm{BP}=\mathrm{Breusch}-\mathrm{Pagan}$ test of heteroscedasticity.

The cumulative sum of recursive residuals (CUSUM) and the CUSUM of square (CUSUMSQ) test proposed by Brown et al. (1975) is employed to investigate the stability of the long-run coefficients. A model is free from instability if the sum of the recursive and squared 
recursive residuals falls within the two critical lines. The resulting plots (available from the authors by request) indicate the stability of the parameter estimates since both the cumulative recursive and recursive square of residuals falls within the critical bounds of 5\% confidence interval. Overall, our models should provide a good approximation of the data used in the analysis.

The results of the F statistics computed for the bound tests, as well as the critical values, are reported in panel B of Table 2. As it appears, there exists a long-run relationship between GDP and tourist arrivals to the United States when tourist arrivals are used as the dependent variable, as indicated by model (2). In other words, tourist arrivals tend to move together with GDP in the long-run. Furthermore, if we include the real effective exchange rates into the model, the bounds test suggest that the three variables revert to a long-run equilibrium as defined by the coefficient estimates of the lagged level variables, as shown in model (1). However, when we use the GDP as the dependent variable, evidence of cointegration disappears, suggesting that GDP perhaps is weakly exogenous to the long-run equilibrium if it does exist.

Panel A of Table 2 reports the estimation results for the ARDL model as described in equation (2). We follow the derivation outlined in equations (3)-(5) and obtain the long-run multipliers as in Table 3. The results based on model (1) suggest that international tourist arrivals in the United States increase by $0.51 \%$ when there is a $1 \%$ economic growth in the United States but decreases by $0.52 \%$ when real effective exchange rate increases by $1 \%$ in the long-run. The positive effect brought about by infrastructure improvement and tourism-related service development from economic growth appears to outweigh the increased cost of travel often observed in developed countries. The results further indicate that if deviations to this long-run equilibrium occur, tourist arrivals will adjust $34 \%$ of the disequilibrium error each month, and half of the disequilibria will be corrected in less than two months (i.e., half-life=1.67 months). For 
models (3) and (4), we do not find a cointegrating relationship when GDP is used as the dependent variable based on the bound test. The adjustment and long-run coefficients of the two models confirm this finding, all of which are of small magnitudes.

Table 3. Long-Run Coefficients Based on ARDL Models in Table 4

\begin{tabular}{lllll}
\hline VARIABLES & $\begin{array}{l}\text { Model (1) } \\
\ln T A_{t}\end{array}$ & $\begin{array}{l}\text { Model (2) } \\
\ln T A_{t}\end{array}$ & $\begin{array}{l}\text { Model (3) } \\
\ln G D P_{t}\end{array}$ & $\begin{array}{l}\text { Model (4) } \\
\ln G D P_{t}\end{array}$ \\
\hline Adjustment coefficient & $-0.340^{* * *}$ & $-0.345^{* * *}$ & $-0.011^{*}$ & $-0.012^{* *}$ \\
& $(0.055)$ & $(0.053)$ & $(0.006)$ & $(0.006)$ \\
\hline $\ln G D P_{t-1}$ & $0.509^{* * *}$ & 0.799 & & \\
$\ln R E E R_{t-1}$ & $-0.518^{* * *}$ & & 0.110 & \\
$\ln T A_{t-1}$ & & & 0.135 & 0.084 \\
\hline
\end{tabular}

Notes: the long-run coefficients are derived from the ARDL models in Table 4. For the adjustment coefficient, numbers in parenthesis are standard errors, and one, two, and three asterisks denote statistical significance at $10 \%$, $5 \%$, and $1 \%$, respectively.

For the short-run parameters reported in Table 2 panel A, a few results deserve attention. First, both dummy variables in the tourist arrival equations are negatively significant, indicating that compared to the base period of 1996-1998, tourist arrivals to the U.S. have on average declined by $22.9 \%$ and $14.2 \%$ in 1999-2011 and 2011-2016, respectively. By contrast, there is no significant difference in GDP growth before or after September 2003, the structural break date identified by the Bai and Perron (1989) least square test. Second, the only remaining variable that is significant in the tourist arrivals model is the lagged exchange rate returns. For the GDP growth equation, both tourist arrivals and exchange rates are significant, though the magnitudes are all very small. However, these coefficients need to be assessed jointly for the combined effect since various lags are included in the estimation.

\subsection{Long-run, short-run, and overall causality}

Next, based on the ARDL model we test the Granger causality from GDP growth to tourist arrivals, as well as from tourist arrivals to GDP growth as specified in equations (6)-(10) and (12) -(16). Testing results are reported in Table 4. 
Table 4. Results of Granger Causality Tests Based on ARDL Models

\begin{tabular}{|c|c|c|c|c|c|c|c|}
\hline \multirow[t]{2}{*}{$\begin{array}{l}\text { Dependent } \\
\text { variable }\end{array}$} & \multicolumn{3}{|c|}{ Short-run causality } & \multirow{2}{*}{$\begin{array}{l}\text { Long-run } \\
\text { causality } \\
\text { F-stat of ECT } \\
E C T_{t-1}\end{array}$} & \multicolumn{3}{|c|}{$\begin{array}{l}\text { Overall causality } \\
\text { Joint F-stat of short- \& long-run }\end{array}$} \\
\hline & $\Delta \operatorname{lnTA}$ & $\Delta \operatorname{lnRGDP}$ & $\Delta \operatorname{lnREER}$ & & $\operatorname{lnTA}$ & $\operatorname{lnRGDP}$ & InREER, \\
\hline$\Delta \operatorname{lnTA}$ & & $\begin{array}{l}1.30 \\
(0.276)\end{array}$ & $\begin{array}{l}3.28 * * \\
(0.039)\end{array}$ & $\begin{array}{l}46.68 * * * \\
(0.000)\end{array}$ & & $\begin{array}{l}16.72 * * * \\
(0.000)\end{array}$ & $\begin{array}{l}17.53 * * * \\
(0.000)\end{array}$ \\
\hline$\Delta \operatorname{lnRGDP}$ & $\begin{array}{l}2.73 \\
(0.067)\end{array}$ & & $\begin{array}{l}2.15 \\
(0.119)\end{array}$ & $\begin{array}{l}3.85 \\
(0.051)\end{array}$ & $\begin{array}{l}3.15^{* *} \\
(0.026)\end{array}$ & & $\begin{array}{l}3.01 * * \\
(0.031) \\
\end{array}$ \\
\hline
\end{tabular}

Note: numbers in parenthesis are standard errors. Two, and three asterisks denote statistical significance at 5\%, and 1\%, respectively.

Turning first to the short-run casualty, we fail to reject the null hypothesis that lagged GDP does not help to predict international tourist arrivals, i.e., GDP does not Granger-cause tourist arrivals in the short-run in the U.S. By contrast, there is a statistically significant causality running from exchange rates to tourist arrivals in the short-run as indicated by the highly significant $F$ statistic. The results should not come as a surprise because exchange rate fluctuations are likely to have a short-term, immediate effect on tourism demand by affecting the affordability of the U.S. as a tourist destination. On the other hand, GDP growth in the U.S., which may have a more longterm effect on infrastructure development, is unlikely to strongly affect tourists' decisions to visit the country in the short-term. We also fail to find statistical evidence that lagged tourist arrivals or exchange rate can predict GDP growth in the U.S.

Regarding the long-run causality, we find statistical significance in the tourist arrivals equation. This suggests that real GDP and real effective exchange rate Granger-cause international tourist arrivals into the United States in the long-run. We also find a strong overall causality running from real GDP, and the real effective exchange rate to international tourist arrivals, as evidenced by the highly significant F-statistics of 16.72 and 17.53 , respectively. By contrast, it appears that real GDP behaves rather independently from tourist arrivals and exchange rate in both 
the short and long-runs, though there exist significant overall causality from these two variables to GDP growth.

The overall results suggest a unidirectional causality running from real GDP and real effective exchange rate to international tourist arrivals in the long-run, and from real effective exchange rate to international tourist arrivals in the short-run. Though tourist arrivals and the exchange rate overall Granger cause GDP growth, we fail to establish causality from the two variables to GDP growth in either the short- or long-run.

\section{Impulse response functions and variance decomposition}

The Granger causality test described above do not provide the details of the dynamic impacts brought about by other variables to the dependent variable. We next employ the generalized variance decomposition and impulse response analysis proposed by Koop et al., (1996), and Pesaran and Shin (1998) to assess the response of tourist arrivals to innovations or shocks from other variables. Specifically, impulse responses are used to examine the dynamic impact of shocks on one variable to another variable (dependent variable) - first the initial response to shocks in another variable, and secondly, whether the shock effect persists or dies out in a short time (Soytas et al., 2007; Soytas and Sari, 2009). Variance decomposition (VDC), on the other hand, indicates the extent to which forecast error variance for the dependent variable is explained by innovations to each explanatory variable over a series of time horizons (Gzaw, 2015). To generate the impulse responses and variance decompositions, we rely on the restricted error correction models - i.e., the vector error correction models derived from the ARDL model as noted in footnote 1 .

Figure 2 plots the impulse response functions of tourist arrivals to a shock in each of the three variables considered in the analysis. We do not examine the response of GDP since we fail 
to find any short- or long-run causality from the other two variables to GDP growth. Consistent with the finding from Granger causality test, an unexpected positive shock to real GDP has a positive and significant effect on international tourist arrivals, which peaks at month five and gradually declines in the following months. However, the effect remains significantly positive after one year. Shocks to the real effective exchange rate initially have a positive and significant impact on tourist arrivals. However, this effect becomes negative and insignificant after six months as indicated in figure 2(c). Additionally, tourist arrivals respond significantly to its own shock, which dies out approximately after six months.

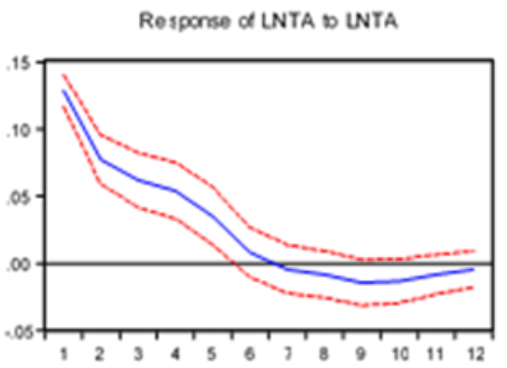

(a)

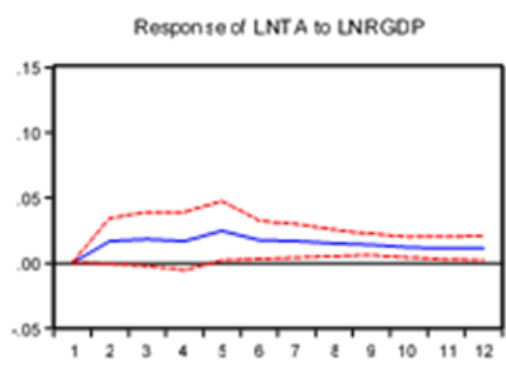

(b)

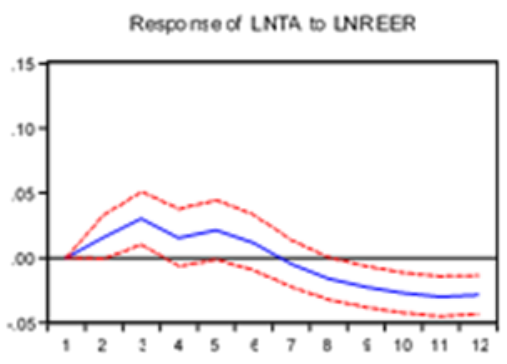

(c)

\section{Figure 2: Responses of Tourist Arrivals to Various Shocks}

The results of the variance decomposition indicating the percentage of forecast error variance of one variable attributable to other variables are reported in table 5. Results suggest that own shocks can explain most of the forecast error variances of both tourist arrivals and GDP, especially at the most immediate horizons. In the short-run (eg.1-3 months), shocks to international tourist arrivals account for over $90 \%$ of error variance in tourist arrivals which gradually declines over the longer-run. Similarly, own shocks of real GDP can explain more than $90 \%$ of their own fluctuations in the short-run, and these impacts remain relatively constant over the longer-run.

Results from Table 5 also indicate that innovations or shocks to real GDP and real effective exchange rate can partially explain the forecast error variance in international tourist arrivals, 
though the percentage of contribution to these shocks are low. At the three-month horizon, $1.98 \%$ and $4.58 \%$ of fluctuations in international tourist arrivals are attributable to innovations in real GDP and real effective exchange rate, respectively. In general, the explanatory power of real GDP and real effective exchange increases over the time horizon, but innovations to the real effective exchange rate explain three times more of the forecast variance of international tourist arrivals compared with innovations to real GDP.

Table 5. Variance Decomposition: \% of Forecast Error Variance Explained by Innovations

\begin{tabular}{lllll}
\hline Dependent variable & Horizon & $\ln$ TA & InRGDP & InREER \\
\hline $\operatorname{lnTA}$ & 1 & 100.00 & 0.00 & 0.00 \\
& 3 & 93.44 & 1.98 & 4.58 \\
& 6 & 88.71 & 4.38 & 6.92 \\
9 & 85.67 & 5.70 & 8.63 \\
& 12 & 78.77 & 6.20 & 12.85 \\
& 15 & 73.34 & 6.90 & 19.76 \\
& 18 & 69.59 & 7.75 & 22.66 \\
$\ln R G D P$ & 21 & 66.16 & 8.50 & 25.34 \\
& 14 & 62.81 & 9.10 & 28.09 \\
& 1 & 2.15 & 97.85 & 0.00 \\
& 3 & 5.37 & 94.29 & 0.34 \\
& 6 & 6.13 & 92.67 & 1.20 \\
& 9 & 5.57 & 92.59 & 1.85 \\
& 12 & 4.83 & 92.52 & 2.65 \\
& 15 & 4.36 & 92.29 & 3.33 \\
& 18 & 4.08 & 92.09 & 3.83 \\
\hline
\end{tabular}

\section{Summary and Conclusion}

The tourism industry in the United States plays an important role in the economy at the local, state, and national levels. The industry has been the source of revenue generation, employment creation, and the development and transfer of human capital, all of which are essential to economic growth. Notwithstanding, very little empirical work has been conducted to explore the nature of the relationship between tourism demand and economic growth in the United States. 
In this paper, we seek to fill this critical gap in the literature by drawing methods from the time series literature.

Using Pesaran et al.'s (2001) bound test, we observed that there exists a long-run relationship between international tourist arrivals, real GDP, and real effective exchange rate based on the monthly data from January 1996 - March 2016. In other words, the three variables move together in the long-run. The Granger causality tests indicate that there exists short-run causal relationship running from real effective exchange rate to international tourist arrivals. The finding is consistent with our prior expectation since the real effective exchange rate measures the effective prices of goods and services in the United States relative to the countries of origin, and hence affects the affordability of the United States as a tourist destination. Furthermore, there exists a strong overall causality and long-run causality from real GDP to international tourist arrivals. By contrast, we fail to find significant causality running from tourist arrivals to GDP growth, either in the short- or the long-run. When both long-run and short-run parameters are combined, we do find tourist arrivals overall affect economic growth. Taken together, our results support the economydriven tourism growth hypothesis in the United States, i.e., the economic growth in the U.S. Granger causes international tourist arrivals into the country. The findings corroborate earlier result of Tang and Jang (2009) which suggest that lagged GDP can help predict the performances of four tourism-related industries in the U.S., including airlines, hotels, casinos, and restaurants. The findings of our study, however, differ from Tang and Jang (2009), which did not find cointegration between tourism and economic growth.

Evidence of the economic-driven tourist growth hypothesis in the United States reinforces the assertion of Lanza et al., (2003) that the hypothesis seems to manifest itself more in highlyindustrialized countries. The reason is that an improving economy through growth in real GDP 
reflects in improved infrastructure development such as good road networks, efficient air and road transportation systems, and developed tourist sites. In addition, economic growth creates an ambient business environment for tourism-related industries such as hotels, restaurants, and casinos. Also developed economies are usually associated with political stability which may attract tourist. These aspects of the economy collectively facilitate the flourishing and proliferation of tourism activities, attracting tourists into that country (Payne and Merver, 2010). The implication therefore is that focus on improving infrastructure developments as it relates to the tourism industry, may result in attracting international tourists to the United States.

The results also point to a significant long-run relationship between real GDP, real effective exchange rate and international tourist arrivals in the United States. We observed that international tourist arrivals in the United States would increases by $0.51 \%$ when there is a $1 \%$ increase in economic growth in the United States, but decreases by $0.52 \%$ when real effective exchange rate increases by $1 \%$ in the long-run. The ARDL model further indicates that when deviations to this long-run relationship occur, each month tourist arrivals will adjust $34 \%$ of disequilibria and over $50 \%$ of the deviations will be corrected within two months.

Finally, generalized variance decompositions and impulse response functions are used to evaluate how each variable respond to innovations to other variables in the system. Results of the variance decompositions indicate that the forecast error variance of international tourist arrivals in the United States is largely explained by its own shocks, perhaps suggesting that visitors to the United States tend to come back and encourages others to do the same. These visitors may share their business, leisure, or holiday experiences with friends and families (by word of mouth), reducing uncertainties for potential visitors to the United States. Under this scenario, policy efforts should be directed at addressing the quality of tourism products at both the micro and macro levels. 
At the micro level, supplies of tourist products should focus on improving service quality that meets the demands of the consumer. In other words, demand for US tourism may be enhanced if the services from tourism industries such as casinos, hotels, restaurants, airlines and other transportations, and shopping malls are improved. The impulse response function, however, indicates that the own shocks of tourist arrivals die out quickly, after a positive and significant impact on itself. This suggests that in the long-run the impact of the word of mouth recommendations, and the tendency for repeated-visits diminishes. To sustain tourism demand in the long-run, the word-of-mouth should be augmented with an effective tourism promotion in the home countries of tourists.

The results further reveal the contribution of real GDP and real effective exchange rate on the forecast error variance international tourist arrivals increases over the time horizon. However, it appears that the percentage of the forecast error variance in tourist arrivals attributable to exchange rates is three times more than real GDP. Combined with the results from the ARDL model and the Granger causality tests, the decision by international tourists to travel to the United States in the short run appears to be influenced more by the exchange rates than the real GDP of the US. In other words, tourist appears to care more about the affordability of the U.S. as a tourist destination and their purchasing power in the U.S. than the infrastructure and other economic growth-related development in the tourist industry. The results from the impulse response further show that the impact of exchange rate die out after some time, while the real GDP persist over time.

Policies aiming to attract international tourists to the U.S. in the long-run should target GDP as its effect persists over a long time. Real GDP growth is a proxy for improved tourismrelated infrastructure development. At the macro level, states and federal authorities could improve 
tourism-related infrastructure development such as roads, airports, transportation system, National parks, and Heritage sites. Therefore, tourist arrivals in the United States can be enhanced even in the short-run if policy focus on improving the services provided in the tourism industries in the US. In the long-run, policy should focus on developing and improving tourism-related infrastructure and increase tourism promotion in the originating countries to address the diminishing word-of-mouth recommendations. To further appreciate the impact of tourism on the individual sectors of the tourism industry, future study should aim at examining the relationship between inbound tourism and tourism sub-industries in the United States. 


\section{References}

Antonakakis, N., Dragouni, M., and Filis, G. (2013). 'Time-varying interdependencies of tourism and economic Growth: evidence from European Countries'. MPRA Munich Personal RePEc Archive, 4875:1-34.

Antonakakis, N., Dragouni, M., and Fills, G. (2015). 'How strong is the linkage between tourism and economic growth in Europe?'. Economic Modelling, 44: 142-155.

Aslan, A. (2014). 'Tourism development and economic growth in the Mediterranean countries: evidence from panel Granger causality tests.' Current Issues in Tourism 17(4): 363-372.

Bai, J., and P. Perron. (2003). 'Computation and analysis of multiple structural change models.' Journal of Applied Econometrics 18, 1-22.

Balaguer, J., and Cantavella-Jorda, M. (2002). 'Tourism as a long-run economic growth factor: the Spanish case.' Applied Economics, 34: 877-884.

Belloumi, M. (2010). 'The relationship between tourism receipts, real effective exchange rate and economic growth in Tunisia.' International journal of tourism research, 12(5): 550-560.

Bureau of Economic Analysis, US Department of Commerce (2014). Tourism satellite accounts 1998-2013. < http://www.bea.gov/industry/index.htm>.

Bureau of Economic Analysis, US Department of Commerce (2015). Tourism Satellite Accounts 1998-2013. < http://www.bea.gov/industry/index.htm>.

Brida, J.G., Carrera, E. and Risso, W.A. (2008). 'Tourism's impact on long-run Mexican economic growth.' Economics Bulletin, 3 (21): 1-8.

Brida J.G., and Pulina, M. (2010). 'A literature review on the tourism-led-growth hypothesis,' CRENoS Working Papers 17, CUEC, Cagliari, Italy. <http://crenos.unica.it/crenos/sites/default/files/WP10-17.pdf>.

Brida, J. G., Cortes-Jimenez, I., and Pulina, M. (2016). 'Has the tourism-led growth hypothesis been validated? A literature review'. Current Issues in Tourism, 19(5), 394-430.

Brida, J. G., and Risso, W. A. (2010). 'Tourism as a determinant of long-run economic growth.' Journal of Policy Research in Tourism. Leisure and Events, 2(1) 14-28.

Brida, J.G., Lanzilotta, B., Lionetti, S., and Risso, W.A. (2010), 'The tourism-led growth hypothesis for Uruguay.' Tourism Economics, 16(3):765-771.

Brown, R.L., Durbin, J., and Evans, J.M. (1975). 'Techniques for testing the constancy of regression relationships over time.' Journal of the Royal Statistical Society, series, 37(2): 149-192.

Candela, G. and Cellini, R. (1997). 'Countries' size, consumers' preferences and specialization in tourism: a note'. Rivista Internazionale di Scienze Economiche e Commerciali, 44: 451457.

Croes, R. (2006). 'A paradigm shifts to a new strategy for small island economies: embracing demand side economics for value enhancement and long-term economic stability,' Tourism Management, 27: 453-465. 
Dritsakis, N. (2004). 'Tourism as a long-run economic growth factor: an empirical investigation for Greece using causality analysis.' Tourism Economics, 10(3): 305-316.

Dritsakis, N. (2012). 'Tourism development and economic growth in seven Mediterranean countries: a panel data approach.' Tourism Economics, 18(4), 801-816.

Durbarry, N. (2004). 'Tourism and economic growth: the case of Mauritius.' Tourism Economics, 10(4): 389-401.

Ertugrul, H.M, and Mangir, F. (2015). 'The Tourism-led growth hypothesis: empirical evidence from Turkey.' Current Issues in Tourism, 18(7): 633-646.

Federal reserve bank of St. Louis. < https://www.stlouisfed.org/>>

Gunduz, L., and Hatemi, J. A. (2005). 'Is the tourism-led growth hypothesis valid for Turkey?'. Applied Economics Letters, 12(8): 499-504.

Gzaw, G.Y. (2015). 'Impact of Ethiopian trade balance: a bound testing approach to cointegration.' Journal of World Economic Research, 4(4): 92-98.

Harris, R., and Sollis, R. (2003). Applied time series modelling and forecasting. Wiley: New York.

Hazari, B., and Sgrò, P.M. (1995). 'Tourism and growth in a dynamic model of trade.' Journal of International Trade and Economic Development, 4(2): 243-252.

Katircioglu, S.T. (2009). 'Revising the tourism-led-growth hypothesis for Turkey using the bounds test and Johansen approach for cointegration.’ Tourism Management, 30: 17-20.

Katircioğlu, S. (2010). 'Research note: Testing the tourism-led growth hypothesis for Singaporean empirical investigation from bounds test to cointegration and Granger causality tests.' Tourism Economics, 16(4)" 1095-1101.

Kim, H.J., Chen, M.H. and Jang, S.C. (2006). 'Tourism expansion and economic development: the case of Taiwan.' Tourism Management, 27: 925-933.

Koop, C., Pesaran, M.H., and Potter, S.M. (1996). 'Impulse response analysis in nonlinear multivariate models.' Journal of Econometrics, 74:119-147.

Lanza, A. and Pigliaru, F. (1995). Specialization in tourism: the case of small open economy, in Coccossis, H. and Nijkamp, P. (eds). Sustainable Tourism Development, Avebury, Aldershort, $91-103$.

Lanza, A., and Pigliaru, F. (2000). 'Why are tourism countries small and fast-growing?', in Fossati, A. and Panella, G. (eds), Tourism and Sustainable Economic Development, Kluwer Academic Publisher, Dordrech, 57 - 69.

Lanza, A., Templec, P., and Urga, G. (2003). 'The implications of tourism specialization in the long run: an econometric analysis for 13 OECD economies'. Tourism Management, 24: $315-321$.

Lee, C.C. and Chien, M.S. (2008). 'Structural breaks, tourism development, and economic growth: evidence from Taiwan.’ Mathematics and Computers in Simulation, 77: 358-368.

Lozano, J., Gomez, C. and Rey-Maquieira, J. (2008). 'The TALC hypothesis and economic growth theory.' Tourism Economics, 14: 727-749.

Macroeconomic advisers. < http://www.macroadvisers.com/about-us/>. 
McKinnon, R. (1964). 'Foreign exchange constraint in economic development and efficient aid allocation.' Economic Journal, 74: 388-409.

Narayan, S., and Narayan, P.K. (2004). 'Determinations of demand for Fiji's exports: an empirical investigation.’ The Developing Economies, 42(1):95-112.

Odhiambo, N. M. (2011). 'Tourism development and economic growth in Tanzania: empirical evidence from the ARDL-Bounds testing approach.' Economic Computation and Economic Cybernetics Studies and Research, 45(3): 71-83.

Oh C. (2005). 'The contribution of tourism development to economic growth in the Korean economy.' Tourism Management, 26: 39-44.

Panagiotidis, T., Panagiotou, T., and Mussoni, M. (2012). 'Tourism led growth: evidence from panel cointegration tests.' The Rimini Centre for Economic Analysis, No. 12-74: 1-27.

Payne, J. E., and Mervar, A. (2010). 'Research note: the tourism-growth nexus in Croatia', Tourism Economics. 16 (4): 1089-1094.

Pesaran, M.H., and Shin, Y. (1998). 'Generalized impulse response analysis in linear multivariate models.' Economics Letters, 58:17-29.

Pesaran, M. H., Shin, Y., and Smith, R.J. (2001). 'Bounds testing approaches to the analysis of level relationships.' Journal of Applied Econometrics, 16: 289-326.

Perron, P. (1989). 'The great crash, the oil price shock and the unit root hypothesis.' Econometrica, 57: 1361-1401.

Phiri, A. (2015). 'Tourism and economic growth in South Africa: evidence from linear and nonlinear cointegration frameworks. MPRA Paper No. 65000 posted $12^{\text {th }}$ June 2015. <http://mpra.ub.uni-muenchen.de/65000>.

Proenca, S., and Soukiazis, E. (2008). 'Tourism as an economic growth factor: a case study for Southern European countries', Tourism Economics, 14(4): 791-806.

Soytas, U., and Sari, R. (2009). 'Energy consumption, economic growth, and carbon emissions: challenges faced by an EU candidate member.' Ecological Economics, 68:1667-1675.

Soytas, U., Sari, R., and Ewing, B.T. (2007). 'Energy consumption, income and carbon emissions in the United States.' Ecological Economics, 62(3-4): 482-489.

Tang, C.H. and Jang, S.C. (2009). 'The tourism-economy causality in the United States: a subindustry level examination.' Tourism Management, 30: 553-558.

Tang, C. F. (2011a). 'Is the tourism-led growth hypothesis valid for Malaysia? A view from disaggregated tourism markets.' International Journal of Tourism Research, 13(1): 97101.

Tang, C.F. (2011b). 'Tourism, real output and real effective exchange rate in Malaysia: a view from rolling sub-samples.' MPRA Paper No. 29379. < http://mpra.ub.unimuenchen.de/29379/>.

Tugcu, C.T. (2014). 'Tourism and economic growth nexus revisited: a panel causality analysis for the case of the Mediterranean Region.’ Tourism Management, 42: 207-212.

UNWTO World Tourism Barometer (2016). www.cf.cdn.unwto.org. 
UNWTO World Tourism Barometer (2017). www.cf.cdn.unwto.org.

U.S. Department of Commerce, Office of Travel and Tourism Industries (OTTI), 'International visitation to the United States', June 2013.

U.S. Travel Association (U.S. Travel), U.S. Travel answer sheet, facts about a leading American industry that's more than just fun, March 2014, <https://www.ustravel.org/sites/default/files/page/2009/09/US_Travel_AnswerSheet_Jun e_2014.pdf>.

Yadzi, S.K., and Khanalizadeh, B. (2017). 'Tourism demand: a panel data approach.' Current Issues in Tourism, 20(8): 787-800.

Zivot, E., and Andrews, D.W.K. (1992). 'Further evidence on the great crash, the oil-price shock, and the unit-root hypothesis.' Journal of Business \& Economic Statistics, 10(3):251-270.

Zortuk, M. (2009). 'Economic impact of tourism on Turkey's economy: evidence from cointegration test.' International Research Journal of Finance and Economics, 1(25): 231239. 


\title{
CHAPTER 3: INDUSTRY-LEVEL ANALYSIS OF TOURISM-ECONOMIC GROWTH IN THE UNITED STATES ${ }^{2}$
}

\begin{abstract}
We investigate the relationship between economic growth and six tourism-related subindustries (accommodation, air transportation, shopping, food and beverage, other transportation, and recreation and entertainment) in the United States in 1998-2017. Except for the lodging and the food and beverage sectors, no long-run relationship exists between other tourism sub-industries and economic growth. We uncover a unidirectional Granger causality from economic growth to each of the sub-industries. Causality is also found between the tourism industries but predominantly from industries providing local offerings (food, entertainment, shopping) to those delivering cross-destination goods and services. Our results suggest that tourism investment could be successful in the long-run even during periods of economic stagnation. In the short-run, however, tourism sectors could benefit from economic growth and tourism-related investment should take a cue from the general economy. Additionally, tourism-related investment and marketing efforts in the U.S. may wish to focus on the food, shopping, and leisure sectors.
\end{abstract}

KEYWORDS: tourism, sub-industry performance, economic growth, Granger causality, cointegration, United States

${ }^{2}$ This chapter has been published in The Tourism Management Journal, Volume 70(2019): pp 333 - 340 


\section{Introduction}

The United States is an important player in the global tourism industry, attracting millions of international visitors per year. Tourists are drawn to the United States for historic sites, national parks and monuments, amusement and theme parks, other recreational and entertainment attractions, as well as culinary, business, health and shopping options. One feature that makes the U.S. a preferred destination for many international tourists is the quality of its tourism goods and services. In 2015, the World Economic Forum constructed the Tourism and Travel Competitiveness Index, a comprehensive index that measures the quality of tourism supply in each destination country. The U.S. performed strongly in the infrastructure and natural and cultural resources components of the index, particularly with air transportation and tourist service infrastructure, world heritage sites, as well as cultural, entertainment, and sports attractions (World Economic Forum 2015). Of the 114 countries considered in the index, the U.S. is ranked first in the Americas and fourth globally after Spain, France, and Germany.

Tourism is currently the most significant service sector within the U.S. economy. In 2017, international and domestic tourists together spent over $\$ 1,035.7$ billion direct travel expenses in the U.S., resulting in $\$ 165$ billion total tax revenues and an additional $\$ 2.4$ trillion indirect and induced expenses (United States Travel Association 2018b). In total, the tourism sector created approximately an $\$ 84$ billion trade surplus in 2016 (United States Travel Association 2017), making it one of the few industries producing a positive trade balance for the U.S. economy. The tourism industry is also among the largest employers within the U.S., generating nearly 7 million indirect and induced jobs in addition to the 8.8 million people directly employed by the industry (United States Travel Association 2018b).

Many studies have investigated the relationship between tourism and economic growth, often finding inconsistent and sometimes even conflicting results. One strand of the literature 
argues for the tourism-led economic growth hypothesis and suggests that the government should engage in tourism development to foster the economic development, while other studies report evidence that the causality runs either from economic growth to tourism or bi-directionally between the two variables. The reasons behind these inconsistencies are multifaceted, with researchers often pointing to the differences in the country considered, the sample period examined, and the empirical methods employed in the analyses.

Mill and Morrison (2002) and Tang and Jang (2009) argue that the treatment of all tourismrelated businesses as a homogenous industry might also account for the inconsistent results found in previous studies. When measuring the performance of the tourism industry, most of the existing studies have used either the overall receipt or the number of patrons to the industry without differentiating between various categories of activities within the sector. Unlike other industries that offer goods with similar characteristics and quality, the tourism industry consists of many subindustries, each providing customers with distinct services such as lodging, dining, transportation, entertainment, etc. These sub-industries may perform differently even under the same economic environment due to the nature of their businesses and likewise may have different relationships with the overall economic growth.

Chen (2007) is the first to empirically examine the tourism-economic growth nexus at the sub-industry level by investigating the relationship between the stock prices of tourism firms (hotels, airlines, and travel agents) and economic development in Taiwan and China. They find that the interactions between stock performance and GDP vary substantially across firms, suggesting the possible existence of differential causal patterns between GDP and individual tourism sub-industries. Tang and Jang (2009) extend the study of Chen (2007) by examining the relationship between aggregate sales revenue from four tourism-related industries (airline, casino, 
hotel, and restaurant) and the economic growth in the U.S. Although the relationship between tourism and GDP is consistent among the four sub-industries in the short-run, they found that the results differ in the long-run-while the airline industry co-moves with GDP, none of the other three industries have a long-run relationship with the economic growth.

This study seeks to revisit the inquiry of Tang and Jang's (2009) sub-industry level analysis by investigating the relationship between economic growth and the real outputs of six major tourism-related industries in the U.S., including food and beverage, recreation and entertainment, air transportation, shopping, accommodations, and other transportation-related commodities. We test the long-run relationship between real GDP and the performances of the six sub-industries using the bounds test of Pesaran et al. (2001), and the causality between each pair of variables using the Toda and Yamamoto (1995) Granger causality test from 1998 to 2017. These two methods are also used to explore the long- and short-run relationships among the six tourismrelated sub-industries.

We find that GDP co-moves with the lodging and the food and beverage industries in the long-run but does not cointegrate with the other four sub-industries. Within the tourism sector, we find that except between other transportation and the air transportation industries, no long-run relationship exists between the remaining pairs of industries. For the short-run, we uncover a unidirectional causality from GDP to each of the six tourism industries. We also observe a meshwork of unidirectional causal interrelationships between the tourism-related sub-industries. Taken together, the performances of the food and beverages, recreation and entertainment, and shopping industries precede those of the accommodation, air, and other transportation industries.

Our paper complements previous sub-industry level analyses of the tourism-economic growth nexus, an area that remains under-investigated. While our results overall agree with the 
economic-driven tourism growth hypothesis found in previous studies for the U.S., we find that industries providing local offerings (e.g., food and beverage, recreation and entertainment, and shopping) are the leading sub-industries within the tourism sector, perhaps because tourists expenditures on these industries are more sensitive to changes in income and the underlying economic activities than those of industries providing cross-destination offerings. Marketing efforts to promote tourism growth may wish to take a cue from, and perhaps even focus on these sub-industries since their performances anticipate the outputs of other sub-industries. Additionally, we find that the performance of the airline industry tends to lag the other sectors, perhaps because of the longer planning horizons of trips involving air transportations than trips to nearby destinations that do not require air travel. Investment decisions in the airline sector should consider the performance of other sub-industries in addition to the general economy as its output lags those of other sectors.

The remainder of the paper is structured as follows. Section two provides a brief review of the tourism-economic growth literature. Sections three and four describe the data and empirical methods used for the analysis, respectively. Results are presented in section five, and the last section concludes the paper.

\section{A Brief Review of the Literature}

An extensive literature has investigated the relationship between tourism and economic growth for various countries, often finding the relationship to vary depending on the specific country examined, the time periods considered, and the methods employed. One strand of literature argues for tourism-led economic growth (TLEG) hypothesis that views tourism as a strategic factor for long-term domestic economic growth, generating direct, indirect, or induced effects on other productive sectors (Tugcu 2014). The TLEG hypothesis has found a wide support in empirical 
studies, including Balaguer and Cantavella-Jorda (2002) who reported a unidirectional causality from tourism to economic growth in Spain, Brida et al. (2010) who found a positive effect of tourism expenditure on GDP per capita in Uruguay, and Dritsakis (2012) that confirmed the beneficial impact of tourism on GDP in seven Mediterranean countries. Similar results are found in Lanza et al. (2003) for 13 OECD (Organization for Economic Co-operation and Development) countries, Durbarry (2004) for Mauritius, Gunduz and Hatemi-J (2005) for Turkey, Proença and Soukiazis (2008) for several southern European countries, Brida and Risso (2010) for South Africa, Belloumi (2010) for Tunisia, and Katircioğlu (2010) for Singapore, among others. In fact, of the 87 empirical studies reviewed, Pablo-Romero and Molina (2013) reported that 55 studies found evidence in support of the TLEG hypothesis.

Contrary to the TLEG hypothesis, the second stream of literature asserts that economic fluctuations are the driving force behind the tourism sector, which is often referred to as the economic-driven tourism growth (EDTG) hypothesis. The reasoning underpinning the EDTG assertion is that resource availability, infrastructure development, and political stability create an ambient economic climate that promotes tourism activities. For instance, using the Engle and Granger two-stage approach and bivariate vector autoregressive model, Oh (2005) found that while no cointegration (i.e., long-run equilibrium) exists between tourism and economic growth, economic growth Granger-causes tourism in South Korea but not vice versa in the short-run. Empirical analyses by Lee and Chien (2008), Payne and Mervar (2010), and Odhiambo (2011) provide further evidence in support of the EDTG hypothesis in various other countries.

A third hypothesis, termed the feedback or reciprocal hypothesis, argues that there exists a bi-directional feedback relationship between tourism and economic growth. For instance, Dritsakis (2004) found that tourism, economic growth, and real exchange rates are cointegrated and that a 
bi-directional causal relationship exists between tourism and economic growth in Greece in 19602000. The reciprocal relationship between tourism and economic growth was also obtained for Taiwan by Kim et al. (2006) and Lee and Chien (2008), for Malaysia by Tang (2011), and for Spain by Perles-Ribes et al. (2017). On the contrary, some researchers have found evidence in support of a fourth hypothesis that no causality exists between tourism and economic growth (e.g., Katircioglu, 2009).

In the present study, we seek to revisit the tourism-economic growth nexus in the U.S., using sub-industry level data that disaggregate the tourism sector into several related industries. Despite the substantial number of papers on the tourism-economic growth relationship, most of the existing work focuses only on the overall performance of the tourism sector (as measured by the overall receipts or total visits), without accounting for the heterogeneity nature of different subindustries. The two sub-industry level analyses, i.e., Cheng (2007) and Tang and Jang (2009), suggest the possible presence of a non-uniform relationship between economic growth and tourism sub-industries. Here, we expand the four categories used in Tang and Jang (2009) to six subindustries, the performances of which are more clearly defined and accurately measured. Methodologically, we employ the improved cointegration and causality tests that avoid certain drawbacks of the conventional methods. The data and methods used in the analysis allow us to more accurately gauge, as well as providing an updated assessment of, the linkage between economic growth and the performance of tourism-related sub-industries in the U.S.

\section{Data}

To measure the performance of tourism-related sub-industries, Tang and Jang (2009) calculated the aggregated sales revenues of individual public-traded firms in the same industry according to the North American Industry Classification System. Since firms in the tourism 
industry often operate businesses in many different countries, the aggregate sales revenue of these multinational companies may fail to reflect the tourism activities in the U.S. Additionally, a significant portion of the firms in the industry are privately owned, the exclusion of which may create large downward bias when measuring the overall performance of each sub-industry using data derived from publically-traded firms. Tang and Jang (2009) also acknowledged that the aggregate sales data might incorporate non-tourism revenues for each sub-industry, further complicating the empirical analysis.

In this paper, we instead use the real tourism output of each sub-industry, comprising of all domestically produced goods and services sold to travelers, as a proxy for their performance. We obtain the quarterly real tourism output estimates from the Bureau of Economic Analysis (BEA) of the U.S. Department of Commerce and the National Travel and Tourism Office for the period of Quarter 1,1998-Quarter 3, 2017. According to the BEA, the real tourism output is calculated by adjusting the estimated total direct tourism output for each industry by chain-type price indexes, yielding the seasonally- and inflation-adjusted annual rates for each quarter (Bureau of Economic Analysis 2017).

Unlike Tang and Jang (2009) who examined the performance of four tourism-related industries - airline, casino, hotel, and restaurants, we expand the scope of the analysis to six major tourism-related sectors-food and beverage (Food), recreation and entertainment (Rec), air transportation (Air), shopping (Shop), travelers' accommodations (Lodging), and other transportation-related commodities (OthTpt), as defined by BEA's Travel and Tourism Satellite Account. The industries considered in the present paper are more expansive, and the detailed economic activities included in each category are more clearly defined than in Tang and Jang (2009). The accommodation, for example, includes hotels, motels, and all other forms of lodging 
used by tourists. The recreation and entertainment industry involve activities travelers engaged in during their leisure time, including gambling, amusement parks and arcades, museums, historical site, skating rinks, ski lifts, day camps, sporting goods, etc. The food and beverage sector include activities occurred in restaurants and other food and beverage spots. Besides air transportation, we also consider all other tourism-related transportation within the U.S., such as rail, water transport, intercity bus, local bus, taxi, car rental, travel arrangement and reservation services, gasoline, etc. For the shopping sector, BEA defined it as "all personal consumption expenditures for nondurable commodities except gasoline" made by tourists during their trips, including cosmetics, clothing, footwear, and other purchases. ${ }^{3}$

Receipts from tourist spending in the six industries during the sample period are plotted in panel A of figure 3. The sector with the highest receipts is other transportation-related commodities, followed by accommodation services and air transportation. The category with the lowest receipts is recreation and entertainment. Tourist expenditures in all six industries suffered a decline in 2001-2003 and 2009-2011, possibly reflecting the macroeconomic and political shocks occurred during these periods. The September 2001 terrorist attack hit the tourism industry particularly hard, as many individuals and groups canceled vacation plans after the attack and changed their subsequent travel decisions. This sharp decline can be seen in figure 3 panel A, where the loss in revenues was particularly pronounced in the accommodation and air transportation industries during this period. The financial crisis that started in the second half of 2008 also adversely affected the tourism industry, as the U.S. economy suffered the largest

\footnotetext{
${ }^{3}$ Though we divide the tourism sector into six sub-industries, each sub-industry still includes a rather diverse set of business activities. This is particularly true for the recreation and entertainment sector, which includes a wide range of activities with different seasonality and business nature. However, we do not have access to more disaggregated data, preventing us from dividing the tourism sector into sub-industries each consisting of homogenous activities. Regardless, by using the six sub-industries as defined by the BEA, our analysis still accounts for some of the heterogeneity not considered in previous studies.
} 
recession in the past half a century and the world economic growth stagnated. During this period, the revenues of all six sub-industries declined.
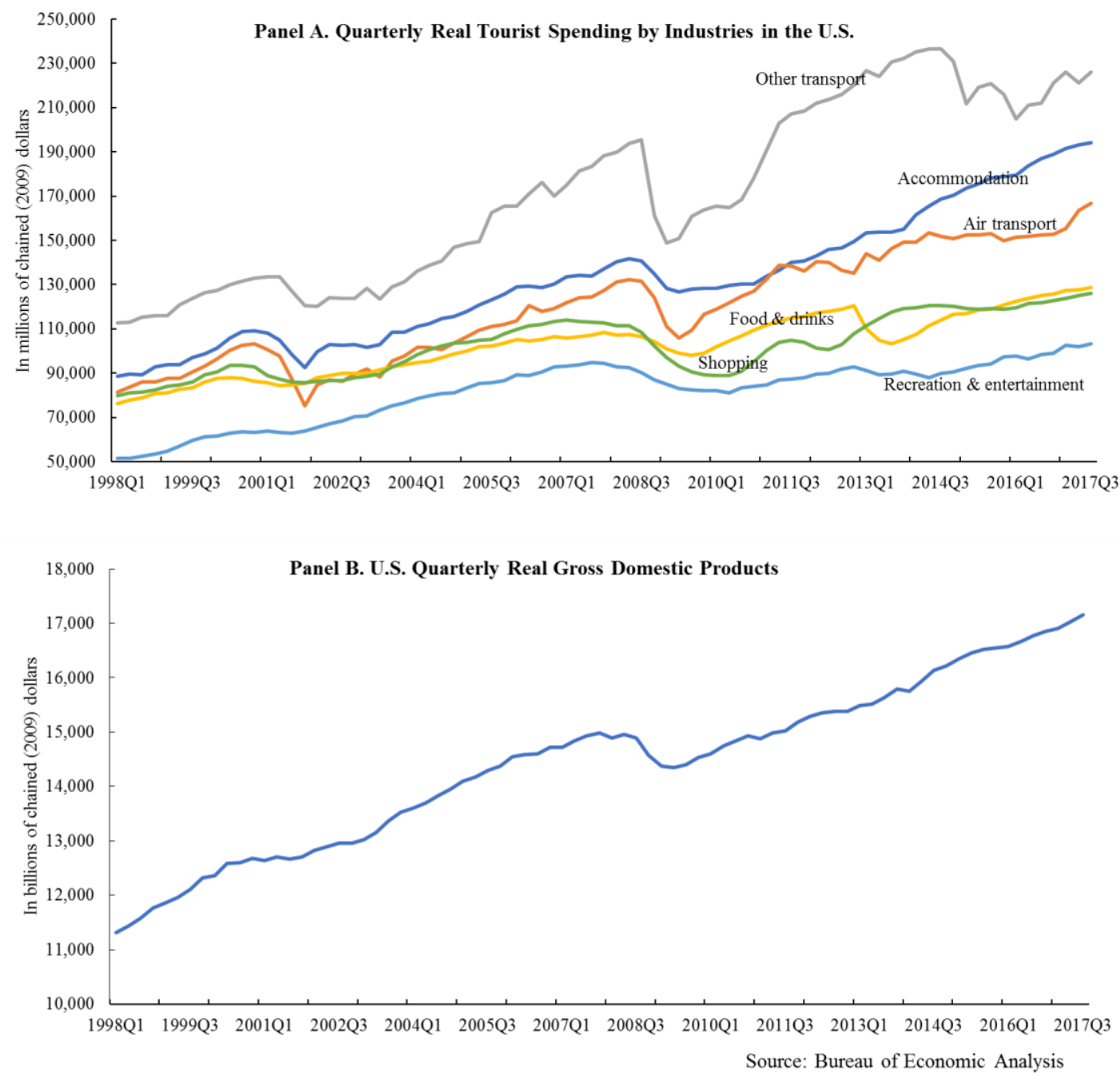

\section{Figure 3. Quarterly Real Tourist Spending by Industries and the Real Gross Domestic Products of the United States, Seasonally Adjusted Annual Rates, 1998Q1-2017Q3}

Panel A of figure 3 also illustrates that while the real output from each sub-industry follows a similar trend, they do behave somewhat differently from time to time. For instance, until 1999 the air transportation industry was the third-largest recipient of tourist expenditure after the other transportation and accommodation sectors. However, the air transportation sector's output 
plummeted to its lowest in 2002, below the outputs of all other industries except recreation and entertainment. It then regained its share in the following few years. Unlike all other industries whose outputs increased in 2013-2014, the expenditures on the food and beverage sector declined during this period. The dissimilarities in how each sub-industry performed during the sample period suggest that they may play diverse roles in the overall economic development, and that economic shocks may affect them differently.

Following the previous literature, we measure the economic growth in the U.S. by its real gross domestic product (GDP), again obtained from the BEA. As can be seen in figure 3 panel B, the real GDP has been trending upwards with a few exceptions, most noticeably between the 20082009 financial crisis. Comparing the two panels in figure 3, while both tourist receipts and GDP increased significantly over the sample period, tourist receipts are more volatile than the GDP.

\section{Econometric Methods}

We employ the autoregressive distributed lag (ARDL) bounds test proposed by Pesaran et al. (2001) to check for the presence of a long-run relationship (i.e., cointegration) between economic growth and the six tourism-related industries, and the Toda-Yamamoto (TY) augmented Granger causality test (Toda and Yamamoto 1995) to determine the direction of causality between the two variables. Compared to the Engle and Granger error correction method and the Johansen maximum likelihood test commonly used in the literature, the bounds test performs well when the sample is relatively small, and is applicable irrespective of the order of the integration of the variables considered (Pesaran et al. 2001). Equation (1) shows the bounds test for two variables, with each variable in turn as the dependent variable: 


$$
\Delta Y_{1 t}=\alpha_{0}+\sum_{i=1}^{p} \beta_{i} \Delta Y_{1 t-i}+\sum_{j=1}^{q} \theta_{j} \Delta Y_{2 t-j}+\eta_{1} Y_{1 t-1}+\eta_{2} Y_{2 t-1}+e_{t}
$$

where $Y_{1}$ and $Y_{2}$ are the variables under consideration, $p$ and $q$ are lag lengths of $Y_{1}$ and $Y_{2}, \beta_{i}{ }^{\prime} s$ and $\theta_{s j}$ represent the short-run coefficients, and $\eta_{1}$ and $\eta_{2}$ denotes the long-run coefficients. The ARDL model in equation (1) can be used to derive the long-run relationship between $Y_{1}$ and $Y_{2}$ by rewriting the model in its error-correction form. Additionally, the F-test for the joint significance of the long-run coefficients (i.e., $H_{O}: \eta_{1}=\eta_{2}=0$ ) can be used to determine whether there exists a long run relationship between $Y_{1}$ and $Y_{2}$. Pesaran et al. (2001) calculated two sets of critical values of the test statistic: lower and upper values that assume regressors are $\mathrm{I}(0)$ and $\mathrm{I}(1)$, respectively. The null hypothesis of no cointegration is rejected if the F statistic exceeds the upper critical value and is accepted if the test statistics falls below the lower critical value. The F-test, however, is inconclusive if the test statistic lies between the lower and upper critical levels.

The sub-industry study by Tang and Jang (2009) uses the conventional Granger (1969) causality test to determine the lead-lag relationship between tourism and economic growth. The test relies on the asymptotic distribution of the test statistic, which may produce spurious results when the variables are non-stationary (Granger and Newbold 1974). Even in the presence of cointegration, the test cannot be carried out with variables specified in levels (Sims et al. 1990). Here, we use the Toda and Yamamoto (1995) approach, which is applicable in the possible presence of unit roots and non-cointegration and has been shown to possess a higher statistical power than the original Granger causality test.

The TY Granger causality test is based on an augmented vector autoregression (VAR) model. Three steps are involved in the test. First, we determine the optimal lag length $(k)$ of the VAR model using the appropriate information criteria. In the second step, we select the maximum 
order of integration $\left(d_{\max }\right)$ using the appropriate unit root tests. These additional lags are added to the VAR model, as in equation (2) for the bivariate analysis:

$$
\left[\begin{array}{l}
Y_{1 t} \\
Y_{2 t}
\end{array}\right]=\left[\begin{array}{l}
\delta_{10} \\
\delta_{20}
\end{array}\right]+\sum_{i=1}^{k}\left[\begin{array}{ll}
\delta_{11, i} & \delta_{12, i} \\
\delta_{21, i} & \delta_{22, i}
\end{array}\right] *\left[\begin{array}{l}
Y_{1 t-i} \\
Y_{2 t-i}
\end{array}\right]+\sum_{j=1}^{d_{\max }}\left[\begin{array}{ll}
\delta_{11, k+j} & \delta_{12, k+j} \\
\delta_{21, k+j} & \delta_{22, k+j}
\end{array}\right] *\left[\begin{array}{l}
Y_{1 t-k-j} \\
Y_{2 t-k-j}
\end{array}\right]+\left[\begin{array}{l}
\varepsilon_{1} \\
\varepsilon_{2}
\end{array}\right]
$$

where $Y_{1}$ and $Y_{2}$ are the two variables defined earlier, $k$ is the optimal lag length selected by information criteria, $d_{\max }$ is the maximum order of integration of the two variables, $\delta$ 's are the parameters in the VAR system, and $\varepsilon$ 's are the errors.

In the last step, we apply the Wald test on the coefficients of the first $k$ lags to determine the causality between the two variables, as in equations (3) and (4):

$$
\begin{aligned}
& H_{0}^{Y_{1 t \rightarrow Y_{2 t}}}: \delta_{21,1}=\delta_{21,2}=\cdots=\delta_{21, k}=0 \\
& H_{0}^{Y_{2 t} \rightarrow Y_{1 t}}: \delta_{12,1}=\delta_{12,2}=\cdots=\delta_{12, k}=0
\end{aligned}
$$

Under the null, the Wald test statistics will be asymptotically chi-square distributed with $k$ degrees of freedom. A rejection of the null hypothesis in equation (3) implies that the lagged values of $Y_{1}$ helps to predict $Y_{2}$ and therefore, suggests the existence of a causality running from $Y_{1}$ to $Y_{2}$. Similarly, a rejection of the null hypothesis in equation (4) suggest that there exists a causality running from $Y_{2}$ to $Y_{1}$.

In testing for causality, the TY approach accounts for non-stationarity of the variables, thus avoiding the inherent problem of the standard Granger causality test (Wolde-Rufael 2006). Additionally, level variables are used in the model to reduce the risk of wrongly differencing the data when the data is in fact stationary (Mavrotas and Kelly 2001). However, it should be noted 
that as with the traditional Granger causality test, the TY testing results only suggest that whether the lagged values of one variable help predict another variable and hence, do not represent the true "causality" between the two variables, i.e., whether a change in one variable leads to a corresponding change in the other. Despite this shortcoming, the Granger-causality type tests are still useful since they indicate whether one variable provides additional forecasting power of another variable beyond what is already included in its own lagged values. Lastly, it should be noted that if two variables are cointegrated, then there must exist Granger causality in at least one direction (see the Granger-Engle representation theorem in Engle and Granger (1987)). However, in the case of no cointegration causality may or may not exist between the variables under interest.

\section{Empirical Results}

As with most time series analysis, we convert all variables into their logarithms to reduce non-normality. The first step of our empirical investigation is to analyze the stationarity property of the variables. Even though the ARDL bounds test does not require all variables to be integrated of the same order, it does require that none of the variables is integrated of order two. Additionally, information on the stationarity property of the variables is required to determine the lag lengths of the TY causality test. Here, we employ the Augmented Dickey-Fuller (ADF) and Phillips-Perron (PP) unit roots test to determine the stationary property of the variables.

Table 6 presents the unit root test results. The optimal lag length used in each testing equation was selected using the Schwarz Bayesian information criterion (SBC). The ADF test suggests that the outputs of the food and beverage, recreation and entertainment, and shopping sectors are stationary at levels, hence are integrated of order zero, while real GDP, travelers' accommodation, air transportation, and other transportation are first-difference stationary, and are 
therefore I(1). The results from the PP test, on the other hand, suggest that all the variables are I(1).

Table 6. Augmented Dickey-Fuller (ADF) and Phillips Perron (PP) Unit Roots Test

\begin{tabular}{|c|c|c|c|c|c|c|c|c|c|c|}
\hline \multirow{3}{*}{ Variables } & \multicolumn{5}{|l|}{$\overline{\mathrm{ADF}}$} & \multicolumn{5}{|l|}{$\mathrm{PP}$} \\
\hline & \multicolumn{2}{|l|}{ Level } & \multicolumn{2}{|c|}{ First Difference } & \multirow{2}{*}{$\begin{array}{l}\text { Order of } \\
\text { integration }\end{array}$} & \multicolumn{2}{|c|}{ Level } & \multicolumn{2}{|c|}{ First Difference } & \multirow{2}{*}{$\begin{array}{l}\text { Order of } \\
\text { integration }\end{array}$} \\
\hline & $\mathrm{C}$ & $\mathrm{C} \& \mathrm{~T}$ & $\mathrm{C}$ & $\mathrm{C} \& \mathrm{~T}$ & & $\mathrm{C}$ & $C \& T$ & $\mathrm{C}$ & $C \& T$ & \\
\hline GDP & -1.12 & -2.54 & $-3.98 * * *$ & $-3.98^{* *}$ & $\mathrm{I}(1)$ & -1.91 & -2.48 & $-5.64 * * *$ & $-5.73 * * *$ & $\mathrm{I}(1)$ \\
\hline Lodging & -0.11 & -1.89 & $-5.94 * * *$ & $-6.00 * * *$ & $\mathrm{I}(1)$ & -0.03 & -1.93 & $-6.57 * * *$ & $-6.62 * * *$ & $\mathrm{I}(1)$ \\
\hline Air & -1.41 & -1.78 & $-8.09 * * *$ & $-8.35 * * *$ & $\mathrm{I}(1)$ & -1.22 & -1.50 & $-8.09 * * *$ & $-8.35^{* * *}$ & $\mathrm{I}(1)$ \\
\hline OthTpt & -0.37 & -1.50 & $-3.63 * * *$ & $-3.82^{* *}$ & $\mathrm{I}(1)$ & 0.49 & -0.73 & $-4.87 * * *$ & $-5.09 * * *$ & $\mathrm{I}(1)$ \\
\hline Food & $-2.55 * * *$ & $-3.59 * *$ & $-4.25 * * *$ & $-4.22 * * *$ & $\mathrm{I}(0)$ & -1.87 & -2.66 & $-4.85 * * *$ & $-4.82 * * *$ & $\mathrm{I}(1)$ \\
\hline Rec & $-2.57 * * *$ & -2.54 & $-2.68 * * *$ & -2.64 & $\mathrm{I}(0)$ & -2.26 & -2.01 & $-5.95 * * *$ & $-6.09 * * *$ & $\mathrm{I}(1)$ \\
\hline Shop & $-2.98 * * *$ & -2.96 & $-3.63 * * *$ & $-3.60 * *$ & $\mathrm{I}(0)$ & -1.78 & -1.77 & $-3.43 * *$ & -3.40 & $\mathrm{I}(1)$ \\
\hline
\end{tabular}

Notes: One, two, and three asteroids denote rejection of the null hypothesis of a unit root at $10 \%$ and 5\%, and $1 \%$, respectively. "C"= model with a constant only, "C \& T"= model with a constant and trend.

\subsection{The relationship between GDP and tourism-related industries}

Since none of the variables are integrated of order 2 , we next investigate the long-run relationship between GDP and tourism sectors using the ARDL bounds test (equation (1)). Since we argue that the relationship between economic growth and tourism can differ by sub-industries, we conduct the pairwise bounds test between GDP and the real output of each tourism-related industry using the latter as the dependent variable. We specify the testing equation in this way because within the same quarter, GDP is more likely to be exogenous to tourism output than the other way around. 
Table 7 reports the computed $\mathrm{F}$ statistics for the pairwise bounds test between tourism industry performance and GDP. The test statistic falls below the lower bounds when air transportation, other transportation, recreation and entertainment, and shopping are used as the dependent variable, presenting evidence in favour of no cointegration between economic growth and the performance of these sectors. Evidence of cointegration, however, is found when traveler's accommodation and food and beverage are used as the dependent variables, suggesting that these two tourism-related sectors co-move with GDP in the long-run. Our results are in general consistent with the conclusion in Tang and Jang (2009) that the linkage between tourism industries and economic growth in the U.S. is weak in the long-run. Unlike Tang and Jang (2009) who found that the airline industry is the only sector cointegrated with GDP, we instead observe a long-run equilibrium between GDP and accommodation, as well as between GDP and the food and beverage industry.

Table 7. Bivariate Bounds Test of Cointegration: Tourism Industries and GDP

\begin{tabular}{|c|c|c|c|c|c|}
\hline \multirow{2}{*}{$\begin{array}{l}\text { Dependent } \\
\text { variable }\end{array}$} & \multirow[t]{2}{*}{ Function } & \multirow[t]{2}{*}{ F-Stat } & \multicolumn{2}{|c|}{ Critical Values } & \multirow[t]{2}{*}{ Decision } \\
\hline & & & Lower & Upper & \\
\hline Lodging & $\mathrm{F}$ (Lodging, GDP) & 5.38 & 4.04 & 4.78 & Cointegration \\
\hline Air & F(Air, GDP) & 4.55 & 4.94 & 5.73 & No cointegration \\
\hline OthTpt & $\mathrm{F}(\mathrm{OthTpt}, \mathrm{GDP})$ & 2.50 & 4.94 & 5.73 & No cointegration \\
\hline Food & F(Food, GDP) & 12.63 & 6.84 & 7.84 & Cointegration \\
\hline $\operatorname{Rec}$ & $\mathrm{F}(\mathrm{Rec}, \mathrm{GDP})$ & 2.06 & 4.94 & 5.73 & No cointegration \\
\hline Shop & $\mathrm{F}$ (Shop, GDP) & 4.58 & 4.94 & 5.73 & No cointegration \\
\hline
\end{tabular}


The weak linkage between tourism sub-industries and the GDP in the long-run suggest that the two may follow rather different long-term paths, at least based on the evidence from our data. Despite its importance, the tourism industry remains a small contributor to the US economy, accounting for $2.7 \%$ of total GDP in 2016 (OECD 2018). Meanwhile, the US economy is highly complexed and diversified, driven by technology innovations, growth in industrial outputs, energy sector expansion, human capital accumulation, rises in domestic and foreign direct investment, as well as many other factors that may only weakly correlate with the tourism sector. The performance of the tourism sector, on the other hand, is highly linked to socio-demographic factors (Zheng and Zhang 2013), political events (Goodrich 2002), visa programs (Cheng 2012), and infrastructure development (Khadaroo and Seetanah 2007) in addition to income. The lack of cointegration relationship between tourism and GDP in the U.S. may thus in part due to the different sets of variables shaping their long-term performances.

We next investigate the direction of causality between GDP and the performance of each tourism-related industry using the Toda and Yamamoto (1995) test (equation (2)). The optimal lag length for the underlying VAR is selected again by SBC. We then check for residual autocorrelation of the VAR model using the Lagrange-Multiplier test. Additional lags are added to the model until autocorrelation disappears to ensure that the underlying VAR is correctly specified ( $k$ lags). Given the maximum order of integration $\left(d_{\max }\right)$ from table 6 , we estimated a $k+d_{\max }$ order VAR model for GDP and the real output of each tourism-related industry, the results of which are presented in table 8.

As can be seen, there exists a unidirectional causality from GDP growth to all six tourismrelated sectors - the lagged GDP anticipates the real output of tourism-related sub-industries but not vice versa. For the causal patterns we identified, evidence of statistical significance is strongest 
from GDP to accommodation and from GDP to air transportation, and the weakest from GDP to other transportation. Our results suggest that the performance of tourism-related industries lags the overall economic cycle in the U.S. and that the relationship between the two conforms to the economic-driven tourism growth (EDTG) hypothesis often observed in developed countries. This finding should not come as a surprise given the small share of tourism output in the U.S. GDP. Additionally, while tourism globally is considered a luxury good, Yazdi and Khanalizadeh (2017) find that the income elasticity of international tourists into the US from 14 nations is less than unity. For domestic tourism that accounts for nearly $80 \%$ of the U.S. total tourism receipts (OECD 2018), Zheng and Zhang (2013) find that the mean income elasticity of tourism expenditure for domestic travellers in the U.S. is 0.54 in 2011. These findings suggest that the international and domestic tourism demand in the U.S. may trail the overall economic performance as they are overall income-inelastic.

Table 8. Toda-Yamamoto Bivariate Granger Causality Test Between GDP and Tourism Sub-Industries

\begin{tabular}{|c|c|c|c|c|c|}
\hline Dep var & Ind variable & Lag length & Chi-sq & Prob & Direction of causality \\
\hline GDP & Lodging & 2 & 3.31 & 0.191 & Unidirectional causality \\
\hline Lodging & GDP & & $15.68 * * *$ & 0.000 & GDP $\rightarrow$ Lodging \\
\hline GDP & Air & 2 & 1.80 & 0.406 & Unidirectional causality \\
\hline Air & GDP & & $17.68 * * *$ & 0.000 & GDP $\rightarrow$ Air \\
\hline GDP & OthTpt & 2 & 1.34 & 0.511 & Unidirectional causality \\
\hline OthTpt & GDP & & $4.77 *$ & 0.092 & GDP $\rightarrow$ OthTpt \\
\hline GDP & Food & 2 & 1.66 & 0.437 & Unidirectional causality \\
\hline Food & GDP & & $9.73 * * *$ & 0.008 & GDP $\rightarrow$ Food \\
\hline GDP & Rec & 4 & 5.87 & 0.209 & Unidirectional causality \\
\hline Rec & GDP & & $8.53 *$ & 0.074 & $\mathrm{GDP} \rightarrow \mathrm{Rec}$ \\
\hline GDP & Shop & 3 & 1.60 & 0.660 & Unidirectional causality \\
\hline Shop & GDP & & $12.44 * * *$ & 0.006 & GDP $\rightarrow$ Shop \\
\hline
\end{tabular}

Notes: One, two, and three asteroids indicate statistical significance at $10 \%, 5 \%$, and $1 \%$, respectively. $\rightarrow$ denotes the direction of causality. 
Meanwhile, many tourism-related businesses require a large upfront investment, making it difficult to adjust supply in the short-run. Tourism supply could be rather inelastic and as in the case of tourism demand, lags the general economic activity. A similar argument was made in Corgel (2004) who shows that the cycles in the hotel industry follow the general business cycles but with a lag.

\subsection{The linkages within tourism-related industries}

A relevant question to the tourism sector is whether the performance of one industry helps predict the performance of another. The goods and services in the individual tourism industries may serve as substitutes or complements and therefore produce different relational outcomes. Furthermore, tourists often consume goods and services from more than one tourism sectors. Against this backdrop, we investigate the lead-lag relationship between the six sub-industries. Such information is of relevance when making investment and marketing decisions as decisionmakers are often faced with resource constraints.

We first apply the bounds test to each pair of tourism industries, the results of which are presented in table 9. With the only exception between the air and the other transportation sectors, we fail to identify any long-run relationship in the remaining pairs of industries. As can be seen in figure 1, while the performance of each sector in general followed a similar trend, there are periods when the real output of one sector is driven by idiosyncratic factors uncorrelated with other industries. The lack of cointegration relationship within the tourism sector suggests that in the long-run, the performance of each sector may behave rather differently, depending predominantly on sector-specific factors.

Table 10 shows the pairwise Granger causality test for the six tourism-related sectors. No causality exists between the food and beverage (Food) industry and three other industries, 
including Rec, Shop, and OthTpt. There is, however, a unidirectional causality running between all other pairs of industries. To provide a clearer picture of the relationship among the six sectors, we plot in figure 4 the directions of causality presented in table 10 .

Table 9. Bivariate Bounds Test of Cointegration Between Tourism Industries

\begin{tabular}{llllll}
\hline Dep var & Function & F-stat & \multicolumn{2}{l}{ Critical Values } & \multirow{2}{*}{ Decision } \\
\cline { 3 - 4 } & & & Lower & Upper & \\
\hline Air & F(Air/Lodging) & 3.833 & 4.94 & 5.73 & No cointegration \\
OthTpt & F(OthTpt/Lodging) & 2.160 & 4.94 & 5.73 & No cointegration \\
Food & F(Food/Lodging) & 3.037 & 4.94 & 5.73 & No cointegration \\
Rec & F(Rec/Lodging) & 3.377 & 4.94 & 5.73 & No cointegration \\
Shop & F(Shop/Lodging) & 4.023 & 4.94 & 5.73 & No cointegration \\
Food & F(Food/OthTpt) & 2.154 & 4.94 & 5.73 & No cointegration \\
Rec & F(Rec/OthTpt) & 2.287 & 4.94 & 5.73 & No cointegration \\
Shop & F(Shop/OthTpt) & 1.363 & 4.94 & 5.73 & No cointegration \\
Air & F(Air/OthTpt) & 6.030 & 4.94 & 5.73 & Cointegration \\
Food & F(Food/Air) & 1.780 & 4.94 & 5.73 & No cointegration \\
Rec & F(Rec/Air) & 2.059 & 4.94 & 5.73 & No cointegration \\
Shop & F(Shop/Air) & 1.747 & 4.94 & 5.73 & No cointegration \\
Rec & F(Rec/Food) & 4.369 & 4.94 & 5.73 & No cointegration \\
Shop & F(Shop/Food) & 2.636 & 4.94 & 5.73 & No cointegration \\
Shop & F(Shop/Rec) & 2.747 & 4.94 & 5.73 & No cointegration \\
\hline
\end{tabular}

Notes: $H_{0}$-no cointegration between GDP and the tourism sub-sector.

Consistent with Tang and Jang (2009), we find that the lodging industry has the most causal links to and from all other industries, making it the pivot sector of the tourism industry that serves as the role of information transmitter within the system. Tang and Jang (2009) further find that the performance of the airline industry precedes the other tourism industries, making it the leading sector in the tourism industry. On the contrary, we observe that the air transportation sector is the recipient of spillover effects from all other industries, with its performance led by the outputs of all other sectors. 
Table 10. Toda-Yamamoto Bivariate Granger Causality Test Between Pairs of Tourism Industries)

\begin{tabular}{lll|lll|l}
\hline Dep V. & Ind V. & Chi-sq & Dep V. & Ind V. & Chi-sq & Direction of causality \\
\hline Lodging & Air & 2.713 & Air & Lodging & $14.792^{* * *}$ & Lodging $\rightarrow$ Air \\
Lodging & OthTpt & 2.204 & OthTpt & Lodging & $6.950^{* *}$ & Lodging $\rightarrow$ OthTpt \\
Lodging & Food & $12.838^{* * *}$ & Food & Lodging & 0.383 & Food $\rightarrow$ Lodging \\
Lodging & Rec & $12.655^{* * *}$ & Rec & Lodging & 0.673 & Rec $\rightarrow$ Lodging \\
Lodging & Shop & $17.726^{* * *}$ & Shop & Lodging & 1.357 & Shop $\rightarrow$ Lodging \\
Air & OthTpt & $9.896^{* * *}$ & OthTpt & Air & 3.730 & OthTpt $\rightarrow$ Air \\
Air & Food & $15.535^{* * *}$ & Food & Air & 2.312 & Food $\rightarrow$ Air \\
Air & Rec & $18.033^{* * *}$ & Rec & Air & 0.136 & Rec $\rightarrow$ Air \\
Air & Shop & $17.572^{* * *}$ & Shop & Air & 1.613 & Shop $\rightarrow$ Air \\
OthTpt & Food & 3.675 & Food & OthTpt & 3.017 & No causality \\
OthTpt & Rec & $6.709^{* *}$ & Rec & OthTpt & 1.256 & Rec $\rightarrow$ OthTpt \\
OthTpt & Shop & $12.452^{* * *}$ & Shop & OthTpt & 1.383 & Shop $\rightarrow$ OthTpt \\
Food & Rec & 0.461 & Rec & Food & 3.810 & No causality \\
Food & Shop & 0.181 & Shop & Food & 1.765 & No causality \\
Rec & Shop & 3.412 & Shop & Rec & $7.967 * *$ & Rec $\rightarrow$ Shop \\
\hline
\end{tabular}

Notes: Model estimated with $d(\max )=1$. Lag length selected by BIC. Additional lags are added to the model until autocorrelation disappears. One, two, and three asteroids indicate statistical significance at 10\%, $5 \%$, and $1 \%$, respectively. $\rightarrow$ denotes the direction of causality.

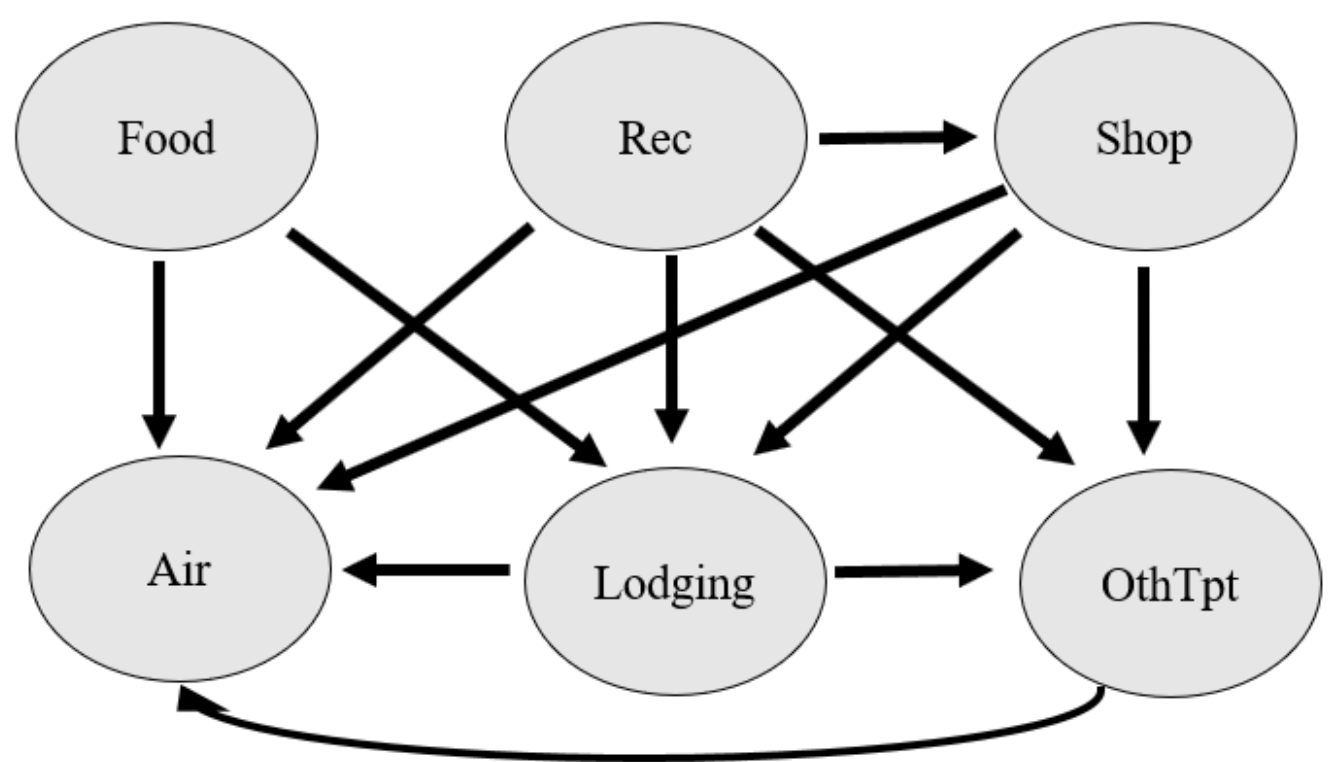

Figure 4: Graphical representation of Granger causality between the tourism-related sub-industries 
The lagging performance of the air transportation sector can perhaps be explained by the different planning horizons of long- vs. short-distance trips. Compared to nearby destinations, trips to more distant destinations often require advanced planning such as coordinating vacation time, saving for the trip, obtaining visas and travel permits, etc. In a booming economy, consumers are likely to increase their expenditures on tourism, but first on nearby destinations, many of which can occur without air travel. As the disposable income grows, tourists could afford more longdistance trips that require not only air transportation but also longer planning horizons. For many travelers, these long-distance trips (or extended vacations) often occur on a later date than nearby trips, with the time difference sometimes go beyond a quarter. The impact of the overall economic condition on the tourism sector may therefore first show up in industries such as lodging, food, shopping, other transportation, and recreation, the goods and services of which are all consumed by tourists in short-distance trips, followed by the air transportation sector that often occur in longdistance trips.

As can be seen in figure 2, if we divide the six industries into two categories, one consisting of sectors providing comparable products in different destinations (i.e., Air, Lodging, and OthTpt) and the other consisting of sectors providing local offerings (i.e., Food, Rec, and Shop), the performance of the latter clearly leads the former. In particular, the recreation and entertainment sector anticipates the output of almost all other sectors. Zheng and Zhang (2013) report that in 1996 and 2011, the mean income elasticity of expenditure on sightseeing and entertainment was 1.31 and 1.26, respectively, based on the Consumer Expenditure Survey by the U.S Bureau of Labor Statistics. Meanwhile, they find that the mean income elasticities of expenditures on lodging, food and beverage, and transportation were all less than unity in both years. Therefore, it is possible that income-induced tourism behavior change due to GDP growth shows up first in the 
recreation and entertainment sector, followed by other sectors whose expenditures are less sensitive to income changes. While we are unaware of income elasticity estimates on tourismrelated shopping expenditures in the U.S., the shopping sector, which includes all personal consumption expenditures excluding gasoline made by a tourist, could be overall rather sensitive to changes in income and the underlying economic activities. The expenditures on the shopping sector, as a result, may anticipate the performance of sectors that are considered more of a necessity to tourists.

The discrepancies between our results and those in Tang and Jang (2009) may be partly due to the use of different datasets and sample periods. The omission of the privately-owned firms and the narrowly-defined sectors in Tang and Jang (2009) could underestimate the role of the food and beverage and the recreation and entertainment sectors. The aggregate sales data could contain a substantial portion of non-tourism and non-US revenues, further complicating the estimation results. Additionally, Tang and Jang (2009) consider a sample period of 1980-2005, whereas in our analysis the sample considered is 1998-2017, a period when growth in leisure travelers' expenditure significantly outpaced business travel expenditures (United States Travel Association 2018a). The rise in leisure travel suggests that activities satisfying personal pleasure, including food, shopping, and recreation play more significant roles than in previous periods. Perhaps even more importantly, since neither Tang and Jang (2009) nor the present study considers contextual variables in the empirical analysis, the differences in the findings could also be due to the effect of other factors that may have evolved over the two study periods.

\section{Conclusion}

This paper examines the relationship between GDP and the real output of six tourism industries in the U.S., and within the tourism industries using quarterly data from 1998 to 2017. 
We find that except for the lodging and the food and beverage sectors, GDP is not cointegrated with any of the remaining tourism sectors. No long-run relationship exists within the tourism industries except between the air transportation and other transportation sectors. The TodaYamamoto causality test indicates that there exists a unidirectional causality running from GDP to the six tourism sectors, supporting the economy-driven tourism growth hypothesis predominantly observed in developed countries where tourism revenues only account for a small portion of the overall economy. Within the tourism sector, the performance of shopping, food and beverage, and recreation and entertainment industries in general leads the output of the other three industries, i.e., air transportation, lodging, and other transportation.

Our results have implications at both the micro and macro levels. Due to the weak linkage between tourism sub-industries and economic growth in the long-run, investment activities to increase tourism revenues may not necessarily need to follow the general business cycle. As contended by Tang and Jang (2009), tourism investment could be successful in the long-term even when the general economy is suffering a sustained stagnation. In the short-run, however, the unidirectional causality from GDP to tourism industries suggest that policies/strategies to market and enhance patronage of US tourism goods and services at the federal, state, and local levels should take a cue from current economic activities. A booming economy and favourable business environment could stimulate investment in roads, transportations systems (by road, air, and water), mobile telecommunication, and other facilities, benefiting the tourism-related sectors. At the micro-level, since investment in the tourism industry may be capital intensive and investors often face resource constraints, the timing of investment should be tied to the performance of the general economy that precedes the tourism industries, which could help investors achieve business success in the short-run. 
The interrelationship among the tourism industries appears to show greater inter-linkages compared to that between GDP and the tourism sub-industries, consistent with the observation that tourists are likely to consume goods and services from different tourism industries. The recreation and entertainment industry appears to be the leading industry in the tourism sector because its performance precedes all other related industries except for the food and beverage industry, contrasting earlier work of Tang and Jang (2009) in which air transportation was the leading sector. We attribute the information-recipient role of the air transportation sector in part to the longer planning horizons of extended vacations, most of which require air transportation, as compared to trips with nearby destinations that often do not involve air transportation. Investment and marketing decisions by public or private parties in the air transport sector, therefore, should be evaluated by jointly considering the performance of other tourism sectors.

We further find that the performances of industries providing local offerings, namely the food and beverage, recreation and entertainment, and shopping industries, in general precede the real output of the other three industries delivering comparable cross-destination services. Therefore, tourism companies and policymakers may wish to direct their marketing efforts toward increasing the visibility of the local culinary, leisure, and shopping options as a means to attract tourists, which in turn could generate spillover effects to other sub-sectors. Due to the multiplier effect on the other sectors, stimulating the growth of the food and beverage, the recreation and entertainment, and the shopping sectors should be treated with a high priority in the U.S.

Additionally, we find that the accommodation industry is the primary channel through which information transmits within the tourism industry, receiving information from food, shopping, and recreation and entertainment sectors while sending information to the air and other transportation sectors. It is the fulcrum around which the rest of tourism sub-industries revolves, 
making it the most connected sub-industry, a finding consistent with Tang and Jang (2009). Therefore, the accommodation sector should be keenly watched when making decisions on public and private investment in all other tourism sectors.

It is evident that examining the causality between economic growth and the disaggregated tourism industry unveils results that are hitherto obscured when aggregated tourism is employed. More research on the purpose of tourist visits and its influence on the industry and general economy is needed to inform the decision making in the government and private sectors in the tourism industry. Future studies may also wish to further explore the reasons behind the leading role of sectors providing local offerings in the tourism sector, as well as the information-recipient role of the air transportation industry. In addition, one limitation of the present paper is that we do not control for other exogenous variables in the empirical analysis, most notably exchange rates that could significantly affect the inbound tourism demand to the U.S. from other countries. While our results should largely be valid for domestic tourism demand which accounts for the bulk of the total tourism expenditures in the U.S., future studies may include the U.S. dollar exchange rates and other exogenous variables so that a more accurate picture of the tourism-economic growth relationship may be obtained. 


\section{References}

Balaguer, J., and M. Cantavella-Jorda. 2002. "Tourism as a Long-Run Economic Growth Factor: The Spanish Case." Applied Economics 34 (7):877-884.

Belloumi, M. 2010. "The Relationship between Tourism Receipts, Real Effective Exchange Rate and Economic Growth in Tunisia." International Journal of Tourism Research 12 (5):550-560.

Brida, J.G., B. Lanzilotta, S. Lionetti, and W.A. Risso. 2010. "The Tourism-Led Growth Hypothesis for Uruguay." Tourism Economics 16 (3):765-771.

Brida, J.G., and W.A. Risso. 2010. "Tourism as a Determinant of Long-Run Economic Growth." Journal of Policy Research in Tourism, Leisure \& Events 2 (1):14-28.

Bureau of Economic Analysis. 2017. Tourism Satellite Accounts 1998-2017. https://www.bea.gov/newsreleases/industry/tourism/tour_glance.htm. http://www.bea.gov/industry/index.htm.

Chen, M.-H. 2007. "Interactions between Business Conditions and Financial Performance of Tourism Firms: Evidence from China and Taiwan." Tourism Management 28 (1):188203.

Cheng, K.M. 2012. "Tourism Demand in Hong Kong: Income, Prices, and Visa Restrictions." Current Issues in Tourism 15 (3):167-181.

Corgel, J. 2004. "Predictive Powers of Hotel Cycles." Real Estate Issues 28 (4):32-36.

Dritsakis, N. 2004. "Tourism as a Long-Run Economic Growth Factor: An Empirical Investigation for Greece Using Causality Analysis." Tourism Economics 10 (3):305-316.

Dritsakis, N. 2012. "Tourism Development and Economic Growth in Seven Mediterranean Countries: A Panel Data Approach." Tourism Economics 18 (4):801-816.

Durbarry, R. 2004. "Tourism and Economic Growth: The Case of Mauritius." Tourism Economics 10 (4):389-401.

Engle, R.F., and C.W. Granger. 1987. "Co-Integration and Error Correction: Representation, Estimation, and Testing." Econometrica:251-276.

Goodrich, J.N. 2002. "September 11, 2001 Attack on America: Impact on Tourism Security." Journal of Travel \& Tourism Marketing 11 (4):1-12.

Granger, C.W. 1969. "Investigating Causal Relations by Econometric Models and Cross-Spectral Methods." Econometrica:424-438. 
Granger, C.W., and P. Newbold. 1974. "Spurious Regressions in Econometrics." Journal of Econometrics 2 (2):111-120.

Gunduz, L., and A. Hatemi-J. 2005. "Is the Tourism-Led Growth Hypothesis Valid for Turkey?" Applied Economics Letters 12 (8):499-504.

Katircioğlu, S. 2010. "Testing the Tourism-Led Growth Hypothesis for Singapore-an Empirical Investigation from Bounds Test to Cointegration and Granger Causality Tests." Tourism Economics 16 (4):1095-1101.

Katircioglu, S.T. 2009. "Revisiting the Tourism-Led-Growth Hypothesis for Turkey Using the Bounds Test and Johansen Approach for Cointegration." Tourism Management 30 (1):1720.

Khadaroo, J., and B. Seetanah. 2007. "Transport Infrastructure and Tourism Development." Annals of Tourism Research 34 (4):1021-1032.

Kim, H.J., M.-H. Chen, and S.S. Jang. 2006. "Tourism Expansion and Economic Development: The Case of Taiwan." Tourism Management 27 (5):925-933.

Lanza, A., P. Temple, and G. Urga. 2003. "The Implications of Tourism Specialisation in the Long Run: An Econometric Analysis for 13 Oecd Economies." Tourism Management 24 (3):315-321.

Lee, C.-C., and M.-S. Chien. 2008. "Structural Breaks, Tourism Development, and Economic Growth: Evidence from Taiwan." Mathematics and Computers in Simulation 77 (4):358368.

Mavrotas, G., and R. Kelly. 2001. "Old Wine in New Bottles: Testing Causality between Savings and Growth." The Manchester School 69 (s1):97-105.

Mill, R.C., and A.M. Morrison. 2002. The Tourism System. 4th ed. Dubuque, Iowa: Kendall Hunt.

Odhiambo, N.M. 2011. "Tourism Development and Economic Growth in Tanzania: Empirical Evidence from the Ardl-Bounds Testing Approach." Economic Computation and Economic Cybernetics Studies and Research 45 (3):71-83.

OECD. 2018. OECD Tourism Trends and Policies 2018. http://www.oecd.org/cfe/tourism/oecdtourism-trends-and-policies-20767773.htm.

Oh, C.-O. 2005. "The Contribution of Tourism Development to Economic Growth in the Korean Economy." Tourism Management 26 (1):39-44. 
Pablo-Romero, M.d.P., and J.A. Molina. 2013. "Tourism and Economic Growth: A Review of Empirical Literature." Tourism Management Perspectives 8:28-41.

Payne, J.E., and A. Mervar. 2010. "The Tourism-Growth Nexus in Croatia." Tourism Economics 16 (4):1089-1094.

Perles-Ribes, J.F., A.B. Ramón-Rodríguez, A. Rubia, and L. Moreno-Izquierdo. 2017. "Is the Tourism-Led Growth Hypothesis Valid after the Global Economic and Financial Crisis? The Case of Spain 1957-2014." Tourism Management 61:96-109.

Pesaran, M.H., Y. Shin, and R.J. Smith. 2001. "Bounds Testing Approaches to the Analysis of Level Relationships." Journal of Applied Econometrics 16 (3):289-326.

Proença, S., and E. Soukiazis. 2008. "Tourism as an Economic Growth Factor: A Case Study for Southern European Countries." Tourism Economics 14 (4):791-806.

Sims, C.A., J.H. Stock, and M.W. Watson. 1990. "Inference in Linear Time Series Models with Some Unit Roots." Econometrica 58 (1):113-144.

Tang, C.-H.H., and S.S. Jang. 2009. "The Tourism-Economy Causality in the United States: A Sub-Industry Level Examination." Tourism Management 30 (4):553-558.

Tang, C.F. 2011. "Tourism, Real Output and Real Effective Exchange Rate in Malaysia: A View from Rolling Sub-Samples." MPRA Paper 29379.

Toda, H.Y., and T. Yamamoto. 1995. "Statistical Inference in Vector Autoregressions with Possibly Integrated Processes." Journal of Econometrics 66 (1-2):225-250.

Tugcu, C.T. 2014. "Tourism and Economic Growth Nexus Revisited: A Panel Causality Analysis for the Case of the Mediterranean Region." Tourism Management 42:207-212.

US Travel Association. 2017. U.S. Travel Exports 2016. https://www.ustravel.org/system/files/media_root/document/Research_FactSheet_Travel-Exports.pdf.

US Travel Association. 2018a. U.S. Travel Forecasts.

US Travel Association. 2018b. Us Travel and Tourism Overview 2017. https://www.ustravel.org/system/files/media_root/document/Research_Fact-Sheet_USTravel-and-Tourism-Overview.pdf.

Wolde-Rufael, Y. 2006. "Electricity Consumption and Economic Growth: A Time Series Experience for 17 African Countries." Energy Policy 34 (10):1106-1114. 
World Economic Forum. 2015. "The Travel and Tourism Competitiveness Report 2015." WwW.weforum.org.

Yazdi, S.K., and B. Khanalizadeh. 2017. "Tourism Demand: A Panel Data Approach." Current Issues in Tourism 20 (8):787-800.

Zheng, B., and Y. Zhang. 2013. "Household Expenditures for Leisure Tourism in the USA, 1996 and 2006." International Journal of Tourism Research 15 (2):197-208. 


\title{
CHAPTER 4. AUGMENTED GRAVITY MODELLING OF INTERNATIONAL TOURISM DEMAND IN THE UNITED STATES
}

\begin{abstract}
To remain competitive in the international tourism market, it is important to understand the factors influencing tourism demand. Drawing on annual data from 27 top tourism markets from 1996 to 2014 and using a variety of econometric methods within the gravity model framework, this chapter aims to investigate the determinants of inbound tourism to the United States. The findings show that the basic gravity factors - incomes in the origin countries and the United States, and the distances between the economic centers of the U.S. and the origin countries are significant determinants of tourism flow to the United States. Other economic variables such as the real effective exchange rate, the relative cost of living, travel cost, trade openness, and capital investment significantly influence tourism demand. We also find that cultural factors such as language and religion; demographic factor like urbanization; and government travel policies like the visa waiver program and the U.S.-China memorandum of understanding are important drivers of inbound tourists travel to the United States. The results also confirm the Linder hypothesis in the U.S. tourism literature. The results from the dynamic model suggest that habit persistence or word-of-mouth account for a substantial percentage of the demand for U.S. tourism.
\end{abstract}

KEYWORDS: Gravity model, Inbound tourism, Linder hypothesis, Poisson Pseudo Maximum Likelihood, System GMM 


\section{Introduction}

The post-World War II era witnessed a great expansion of the global tourism industry. It has become not only the world's largest source of foreign exchange receipts (Vietze, 2008) particularly for developing economies, but also a significant contributor to globalization that has generated economic and cultural interdependence across nations. The United States is the single largest destination for global long-haul travel, and international travel to the country is the single largest services sector, accounting for $31 \%$ of all U.S. service exports and $10 \%$ of all goods and services. In addition to generating $2.6 \%$ of the GDP, the tourism industry created 7.6 million jobs in the U.S., of which 1.2 million jobs are supported by spending from international visitors. As shown in figure 5, international visitor arrivals to the U.S. have generally been trending upwards over the years. A similar trend is observed for spending by international visitors, which has more than doubled from about \$93 billion in 1995 to about \$245 billion in 2016.

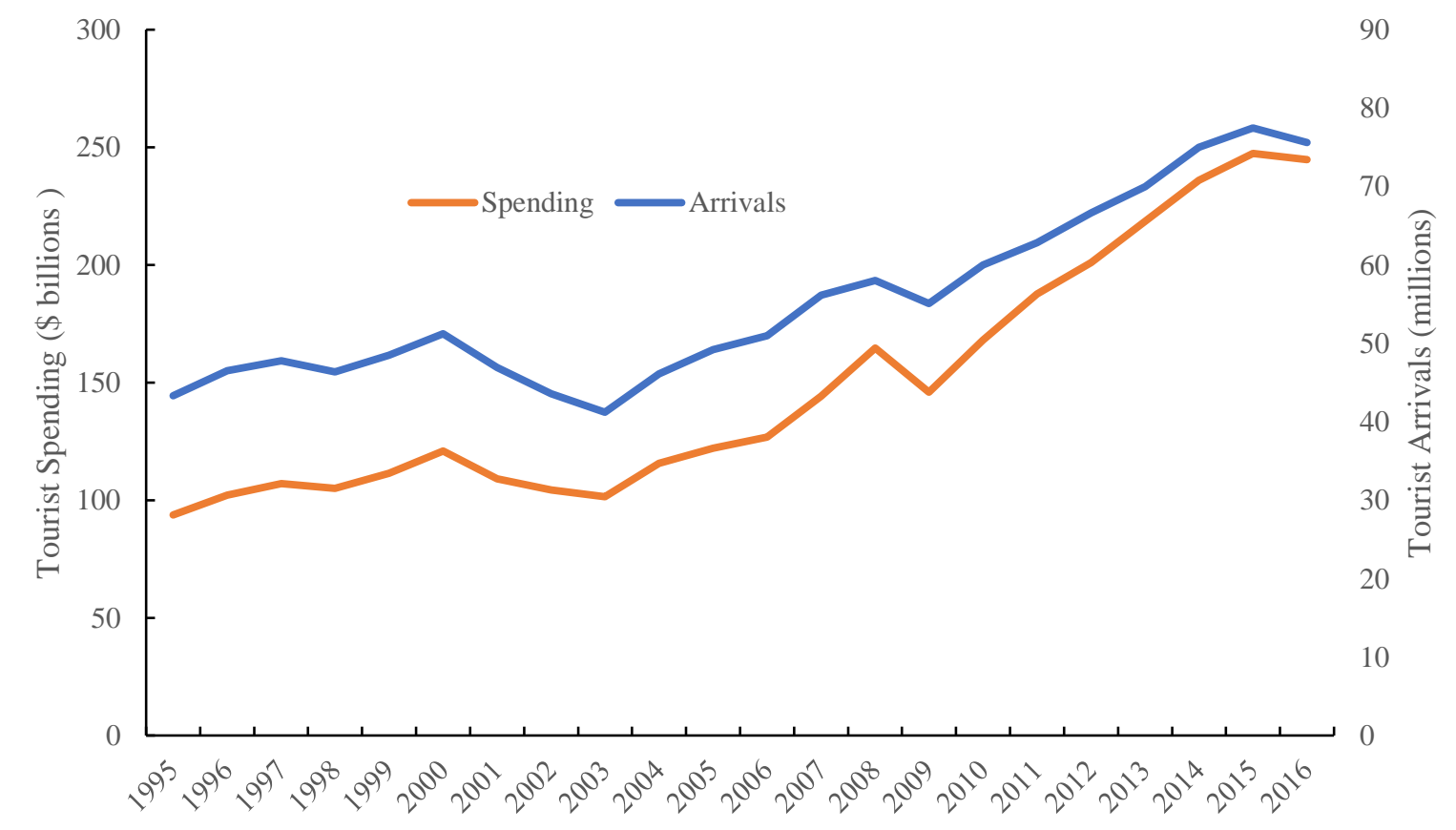

Source: Data from World Development Indicators

Figure 5. International Visitors and Spending in the United States (1995-2016). 
While the number of international visitors to the United States is projected to keep growing in the next few years (ITA-NTTO, 2016), the global tourism industry is becoming increasingly competitive. Many other countries are actively marketing themselves as a preferred tourist destination to capture a share of the global tourism market. Since 1995, advanced economies have been losing market share of tourist arrivals to emerging economies (ITA-NTTO, 2015). The aggressive competition for tourists from other countries caused the U.S. to embark on intervention programs to remain competitive in the tourism market. These programs include the Travel Promotion Act (TPA) $)^{4}$ of 2009 and later the Travel Promotion, Enhancement, and Modernization Act (TPEMA) $)^{5}$ all aim at attracting international tourist to the United States.

These efforts (legislation and travel task force) indicate the recognition of the growing importance of tourism to the U.S. economy. However, studies examining the determinants of international visitors to the U.S. remain scanty. Ekanayake et al. (2012) investigated the tourism demand fro the U.S. from 50 countries between 1986 and 2011, and found the relative prices and the cost of travel between the origin country and the U.S. to significantly influence international tourism demand. Vietze (2012) examined the effect of cultural and governance factors on tourist flow from 208 countries into the U.S. between 2001 to 2005 using a gravity model, finding that tourists from Christian and English-speaking countries prefer the U.S. as a destination for holidays than tourists from another background. Building on previous studies, Deese (2013) found that tourists from higher-income, English-speaking, and bordering countries visit the U.S. more often

\footnotetext{
${ }^{4}$ The Travel Promotion Act (TPA) of 2009, was passed by the U.S. Congress, and signed into law in March 2010. Under the TPA, a non-profit Corporation for Travel Promotion (CTP) was established to disseminate information among potential travelers to the U.S. The TPA also calls for the establishment of the Office of Travel Promotion, which will help disseminate information on entry procedure to arriving visitors, collect data on total numbers of international visitors to each state, and enhance the entry and exit experience for visitors.

${ }^{5}$ The Travel Promotion, Enhancement, and Modernization Act (TPEMA), which extended the authorized period from 2015 to 2020. In 2012, the U.S. government released a new National Travel and Tourism Strategy to develop programs encouraging international travelers to choose the U.S. as the world's premier tourism destination, aiming to attract 100 million international visitors by 2021
} 
than others. In a recent study, Yazdi and Khanalizadeh (2017) found that real income, consumer price index, exchange rate, certain specific events, as well as transport infrastructure significantly affect tourist arrivals in the U.S.

This chapter aims to comprehensively investigate the drivers of international tourist arrivals to the U.S. between 1996 and 2014. It contributes to the existing literature in a number of ways. First, while the aforementioned studies have examined various economic, social, and cultural drivers of international tourism demand for the United States, the impact of consumer taste, relative tourism price of competing countries, trade relation between the U.S. and the origin country, and demographic factors on tourism demand in the U.S. has not been addressed. Omitting these important variables in the regression model may not only bias the econometric estimation results, but also lead to misleading conclusions regarding the driving forces of international tourism demand for the United States.

Second, while earlier research investigated the effect of the September 11, 2001 terrorist attacks on the U.S. tourism industry using dummy variables, this study examined the impact of casualties from terrorist attacks in the U.S. and origin countries on international tourism demand. Since terrorist attacks may produce different levels of casualties with varying impact on tourism demand, we include variables that measure the number of fatalities due to terrorist attacks in the U.S. and the origin country to our model. Additionally, we test whether economic similarity plays a role in attracting international tourists to the United States, a theory often termed the Linder hypothesis in the international trade literature.

An important drawback of previous studies is that most relied on fixed or random effect panel models, which could suffer from estimation bias due to endogenous explanatory variables and invalid inferences due to heteroscedasticity. We instead rely on the newly developed Poisson 
Pseudo Maximum Likelihood that is most appropriate for panel gravity model analysis. Furthermore, the Generalized Method of Moments (GMM) is employed for the dynamic model, using internally generated instruments that correct for endogeneity problem, to evaluate the impact of previous travel and economies of the origin and destination countries on tourism demand.

The results suggest that the variables in the basic gravity model such as incomes in the origin and destination countries, and distances between them are significant determinants of tourism in the United States. From the dynamic model, habit persistence and/or word-of-mouth significantly influence tourism demand for the U.S. Other economic variables such as relative price, tourism price, travel cost, and capital investment also play a significant role in the tourist arrivals into the United States. Additionally, the results support the Linder hypothesis in the U.S. tourism literature that economic similarity tends to draw more international tourists. Overall, our findings reveal that demographic, cultural, some government policies and incidental factors are important considerations in the decision of tourists to travel to the United States.

The remainder of the chapter proceeds as follows. Sections two and three discuss the model specification and data sources, respectively. Section four presents the empirical results and discussions and conclusions are presented in section five.

\section{Model Specification}

The gravity model can be traced to Newton's Law of Gravity in physics, which states that the attraction between two bodies is proportional to the product of their mass and inversely related to the distance between their respective centers of gravity. Economists subsequently adopted Newton's gravitational law to explain the movement of goods and factors between regions (Walter, 1954; Christie, 2002; Deluna and Joen, 2014), as well as the movement of visitors from the originating to a destination country (Vietz 2012). Analogous to Newton's gravitational law, the 
basic assumption of the gravity model of tourism is that the bilateral tourist flows depend on the relative factor abundance and the distance between the economic centers of the two countries involved. We follow previous studies (e.g., Vietz 2012) and employ the gravity model to investigate the determinants of the international tourist demand for the U.S. from individual countries.

Specifically, the international tourism flow to the U.S. is modeled as a function of the economic size (a proxy for relative economic capacity) and the distance between the originating country and the U.S., as in equation (1):

$$
T A_{i t}=f\left(R G D P_{i t}, R G D P_{u t}, D i s t_{i u}\right)
$$

where $T A_{i t}$ is the international tourist arrivals from country $i$ (origin) to the U.S (destination) at time $t, D i s t_{i u}$ is the distance between origin country $i$ and the U.S., and $R G D P_{i t}$ and $R G D P_{u t}$ are the real gross domestic product of country $i$ and the U.S. at time $t$, respectively. The inconvenience of a long flight and the associated cost will have a consequential effect on a tourist decision to travel abroad. The distance variable, measured as the distance between the capitals (or economic centers) of the destination and origin countries, is expected to have a negative relationship with tourism demand.

Economic capacity in the host and origin countries is often measured by income. Previous studies have highlighted the role of income in the decision-making of international tourists (Ledesma-Rodriguez et al., 1999), though sometimes with conflicting results on the income elasticity of tourism demand. Crouch and Shaw (1992) reported that international tourism is a luxury good, with the income elasticity of demand ranging between one and two. However, Yazdi and Khanalizadeh (2017) find that the income elasticity of international tourists into the US from 14 main countries is less than unity. 
Equation (1) can be transformed to an empirical model using the exponential function and taking logarithms of both sides assuming a multiplicative error term:

$$
\ln T A_{i t}=\alpha+\beta_{1} \ln R G D P_{i t}+\beta_{2} \ln R G D P_{u t}+\beta_{3} \ln D i s t_{i u}+\ln \epsilon_{i t}
$$

where $\ln \epsilon_{i t}$ is the multiplicative error term and the $\beta \mathrm{s}$ are the estimated coefficients (gravitational forces) of the incomes of the source and host countries and the distance between them. We further augment the basic gravity model of tourism with other economic and non-economic factors from both the originating and the host countries in equation (3). These augmented factors, $A_{i t}$, include other economic variables, incidental factors, government policies, demographic factors, governance indicators, and cultural factors, which are discussed in section three.

$$
\ln T A_{i t}=\alpha+\beta_{1} \ln R G D P_{i t}+\beta_{2} \ln R G D P_{u t}+\beta_{3} \ln D i s t_{i u}+\Gamma A_{i t}+\ln \epsilon_{i t}
$$

Extant studies have used the pooled, random or fixed effect models in analyzing panel data. The fixed effects model is limited by its inability to estimate time-invariant variables. Furthermore, the presence of heteroscedasticity and serial correlation in the fixed effect model may affect the efficiency of the estimates. While the random effects model allows for the estimation of timeinvariant variables because it assumes the error term to be random, the random effect estimator could be biased due to the covariance between the error term and the explanatory variable.

Here, we employ the Poisson Pseudo Maximum Likelihood (PPML) model because of its desirable properties for the gravity model. In equation (3) the error term is likely to be endogenous as the expected value of $\ln \epsilon_{i t}$ depends on higher moments of $e_{i t}$, including its variance which is likely to be heteroskedastic. The PPML model addresses the heteroscedasticity problem in equation (3), which not only affects the standard error but also the unbiasedness of the coefficient estimates (Silva and Tenreyro, 2006). It is also consistent in the presence of fixed effects. 
Furthermore, it addresses the sample bias in OLS by including zero observations naturally and without any addition to the model (Silva and Tenreyro, 2006). Finally, the coefficients from the Poisson model is interpreted as elasticities, like that of the OLS even though the dependent variable is specified in levels rather than in logarithms. In practice, the PPLM estimator is equivalent to running nonlinear least squares on the original equation.

In addition to the static PPML model, a dynamic model as in equation (4) is employed to estimate the effect of previous tourist arrivals (tourist preference/word-of-mouth), GDP of the origin and destination countries.

$$
\begin{aligned}
& \ln T A_{i t}=\alpha+\beta_{1} \ln T A_{i t-1}+\beta_{2} \ln R G D P_{i t-1}+\beta_{3} \ln R G D P_{u t-1}+\beta_{4} \ln R G D P_{i t}+\beta_{5} \ln R G D P_{u t} \\
& +\beta_{6} \operatorname{lnDist}_{i u}+\Gamma A_{i t}+\delta_{i}+\lambda_{t}+\epsilon_{i t}+
\end{aligned}
$$

where $\delta_{i}$ and $\lambda_{t}$ are the country and time fixed effects, respectively. The error term $\varepsilon_{i t}$ is assumed to be serially uncorrelated with zero mean and independently distributed across countries, but heteroskedasticity across time and countries is allowed for. In addition, $\epsilon_{i t}$ is assumed to be uncorrelated with the initial condition $\ln T A_{i t}$, for $t=2, \ldots, T$, and with the individual effects $\delta_{i}$ for any time $t$.

The inclusion of the lagged tourist arrivals can be justified by at least two reasons. First, existing studies often use previous international tourist arrivals as a proxy for tourist preference (e.g., Bashagi and Muchapondwa, 2009), which can affect the shape of the indifference curve and therefore considered a critical factor determining the demand for tourism goods and services. Additionally, tourists may likely return to the same destination if the earlier visit was enjoyable (Song et al., 2009). They may also recount their experiences and recommend the same destinations to families, friends, and others, commonly known as the 'Word-of-Mouth' (WOM) effect. 
However, the inclusion of lagged variables in the model may produce biased and inconsistent estimators (since the dependent variable is a function of the error term, it follows that the lagged dependent variable is also a function of the error term and so therefore correlates with the error term), except for large time periods towards infinity (Baltagi, 1995). The estimates from OLS which omits the destination-specific effects may also be biased if these effects are relevant. We therefore model equation (5) using the Generalized Method of Moments (GMM) that allows for dynamic effects (Pllaha, 2012) and addresses endogeneity problem through internally generated instruments (Greene, 2008). Specifically, the system GMM procedure by Arellano and Bover (1995) is considered. Briefly, the system GMM is an augmented version of the differenced GMM by Arellano and Bond (1991) that uses the level equation (equation 4) to obtain two equations: one differenced (as in equation 5) and the other in levels. The variables in the second equation are instrumented with their own first differences, and this increases efficiency. The dynamic model is differenced as below:

$$
\begin{aligned}
\Delta \ln T A_{i t}=\alpha+ & \beta_{1} \Delta \ln T A_{i t-1}+\beta_{2} \Delta \ln R G D P_{i t-1}+\beta_{3} \Delta \ln R G D P_{u t-1}+\beta_{4} \Delta \ln R G D P_{i t} \quad \beta_{5} \Delta \ln R G D P_{u t} \\
& +\beta_{6} \Delta \ln D i s t_{i u}+\Gamma \Delta A_{i t}+\epsilon_{i t}
\end{aligned}
$$

where $\Delta$ is the difference operator, and all other variables maintain the same interpretation. The dynamic model allows us to obtain both short- and long-run elasticities, the latter of which is generated by dividing each of the coefficients with $\left(1-\beta_{1}\right)$. Furthermore, differencing data in the dynamic model helps solve the problem of non-stationarity.

\section{Additional Variables and Sources of Data}

The decision to undertake international trips is complex, involving a choice among competing demands. In addition to factor abundance and the distance between the destination and 
originating countries, a variety of other variables that could affect inbound tourism in the U.S., including tourist preferences/habit persistence, economic factors, government policies, cultural factors, demographic factors, as well as governance indicators were considered. Table 11 list all the variables, their expected relationship with tourist arrivals to the U.S., and the sources of data.

\subsection{Economic Variables}

\section{Real Effective Exchange Rate}

The value of the currency of the origin country relative to the destination country is an important consideration in the decision making of tourist. An increase in the strength of the currency in the origin country relative to the destination country portend higher demand for goods and services in the destination country. The real effective exchange rate is therefore expected to negatively impact inbound tourism.

\section{Travel Cost}

While we include the distance variable in the basic gravity model, it may not account for the full travel cost and the inconvenience to travel between the origin and destination countries. Since we consider the international tourism demand for the U.S. over 19 years, it is possible that the travel cost to the U.S. varied significantly even for the same origin country due to change in fuel prices (e.g., jet fuel and gasoline). We therefore interact with the distance variable with crude oil prices to generate an alternative measure of travel cost, which is expected to negatively affect the tourist flow.

\section{Relative Cost of Living in the Origin Country}

A major component of the tourism cost is the expenditure incurred in the destination country, including accommodation, tour services, food, drink, entertainment, shopping, etc. The 
international tourist flow to the U.S. is expected to decrease when it becomes more expensive to procure goods and services in the host country. Here, we construct the relative price level indices using equation (6):

$$
R P_{i t}=P P P_{i t} / E R_{i t}
$$

where $R P_{i t}$ is the relative price index of country $i$ at $t$ compared to the U.S., and $P P P_{i t}$ and $E R_{i t}$ are the purchasing power parity (PPP) and the market exchange rate of country $i$ 's currency relative the US dollars at time $t$, respectively. The PPP measures the ratio of prices in domestic currencies for the same bundle of goods and services in different countries and are sometimes considered a measure of a country's real exchange rate. When adjusted by its market exchange rate to the U.S. dollars, the PPP of country $i$ (equation (6)) measures the relative price level for the same bundle of goods and services in the country as compared to the U.S.

\section{Tourism Prices in Alternative Destinations/Substitute Prices}

The tourism prices in the alternate or competing destinations that share geographical and cultural similarities may influence tourism demand in the original destination. The higher the tourism prices in the alternative destination, the more likely are international tourists to visit the U.S. In other words, a decrease in the price level in the destination country (United States) relative to the competing countries (Canada and Mexico) will encourage tourist flow to the destination country. The variable is expected to have a negative effect on the tourism arrivals to the U.S. The substitute price is constructed as a weighted average index of the tourism prices of the selected alternative destinations (Canada and Mexico):

$$
S P_{t}=\sum_{j=1}^{n}\left(P P P_{j t} / E R_{j t}\right) * w_{j t}
$$


where $j=1, \ldots, n$ represents the selected alternative destinations, $P P P_{j t} / E R_{j t}$ is a measure of tourism prices in destination $j$ at $t$, and $w_{j t}=T A_{j t} / \sum_{j=1}^{n} T A_{j t}$ is the share of international tourist arrivals to destination $j$, where $T A_{j t}$ is the number of tourist arrivals to destination $j$ at time $t$.

\section{Trade Openness}

The demand for international tourism may also be affected by the trade relationship between the origin and host countries. The closer the two countries are economically linked due to international trade; the more business travels will take place between the two countries- to either start up new ventures or negotiate new business and trade deals. Leisure tourists may also visit a destination with a close economic tie to its home country as they may be more familiar with the goods and services in that country through trade flows. Additionally, business travelers may later return to the countries they visited during business trips with family or friends for leisure. To measure the trade openness between the U.S. and another country $(i)$, we calculate the share of the sum of the exports and imports values between the two countries in their total GDP, as in equations (8) and (9). These variables are also termed "trade openness" in previous studies.

$$
\begin{aligned}
& T R_{t}^{i \rightarrow U S}=\sum_{j=1}^{n}\left(\operatorname{Export}_{i, t}^{U S}+\operatorname{Import}_{i, t}^{U S}\right) / G D P_{t}^{U S} \\
& T R_{t}^{U S \rightarrow i}=\sum_{j=1}^{n}\left(\operatorname{Export}_{U S, t}^{i}+\operatorname{Import}_{U S, t}^{i}\right) / G D P_{t}^{i}
\end{aligned}
$$

where $T R_{t}^{i \rightarrow U S}\left(T R_{t}^{U S \rightarrow i}\right)$ is the share of the total value of the imports and exports between the two countries in the total GDP of the U.S. (country $i$ ). 
Table 11. Variables Used in the Analysis

\begin{tabular}{|c|c|c|c|}
\hline Variables & Explanation & $\begin{array}{l}\text { Effect } \\
\text { on TA }\end{array}$ & Sources of data \\
\hline$T A_{i t}$ & Tourist arrivals to the U.S. from $i$, in millions & $(+)$ & $\begin{array}{l}\text { Office of Travel and Tourism Services, the U.S. } \\
\text { Department of Commerce }\end{array}$ \\
\hline$R G D P_{i t}$ & GDP in $i$, in real terms & $(+)$ & IMF financial statistics \& World Bank \\
\hline$R G D P_{u t}$ & GDP in the US, in real terms & $(+)$ & IMF financial statistics \& World Bank \\
\hline Dist $_{i u}$ & Distance between economic centers of $i$ and U.S & $(-)$ & http://www.geobytes.com \\
\hline$R E E R_{i t}$ & Real effective exchange rate of $i$ in the US & $(-)$ & IMF financial statistics \& World Bank \\
\hline$T C_{i t}$ & Travel cost, product of distance and oil price & $(-)$ & $\begin{array}{l}\text { US Energy department \& } \\
\text { http://www.geobytes.com }\end{array}$ \\
\hline Capinvest $_{t}$ & Capital investment in the U.S. in real terms & $(+)$ & World Travel and Tourism Council (WTTC) \\
\hline$R P_{i t}$ & $\begin{array}{l}\text { Relative cost of living in } i \text { compared to the U.S., ratio of } \\
\text { PPP over market exchange rate }\end{array}$ & $(-)$ & $\begin{array}{l}\text { PPP \& exchange rates from OECD } \\
\text { https://data.oecd.org/ }\end{array}$ \\
\hline SPcan $_{t}$ & $\begin{array}{l}\text { Substitute prices, weighted average of relative cost of } \\
\text { living in alternative destinations (Canada) }\end{array}$ & $(-)$ & $\begin{array}{l}\text { PPP \& exchange rates from OECD } \\
\text { https://data.oecd.org/ }\end{array}$ \\
\hline SPmex $_{t}$ & $\begin{array}{l}\text { Substitute prices, weighted average of relative cost of } \\
\text { living in alternative destinations (Mexico) }\end{array}$ & $(-)$ & $\begin{array}{l}\text { PPP \& exchange rates from OECD } \\
\text { https://data.oecd.org/ }\end{array}$ \\
\hline$T R_{t}^{i \rightarrow U S}$ & $\begin{array}{l}\text { Trade openness, } \% \text { of total import-export values } \\
\text { between } i \& \text { U.S. over U.S. GDP }\end{array}$ & $(+)$ & DTS of IMF \& World Bank \\
\hline$T R_{t}^{U S \rightarrow i}$ & $\begin{array}{l}\text { Trade openness, } \% \text { of total import-export values } \\
\text { between } i \text { \& the U.S. over } i \text { 's GDP }\end{array}$ & $(+)$ & DTS of IMF \& World Bank \\
\hline Linder $1_{i t}$ & Economic similarity, $\left|G D P_{i t}-G D P_{t}^{U S}\right|$ & $(-)$ & IMF financial statistics \& World Bank \\
\hline Linder $2_{i t}$ & $\begin{array}{l}\text { Economic similarity, }\left|G D P_{i t}-G D P_{t}^{U S}\right| /\left(G D P_{i t}+\right. \\
\left.G D P_{t}^{U S}\right)\end{array}$ & $(-)$ & IMF financial statistics \& World Bank \\
\hline$V W P_{i}$ & $\begin{array}{l}\text { Whether } i \text { is a participant of the U.S. Visa Waver } \\
\text { Program }\end{array}$ & $(+)$ & U.S Department of state; http://travel.state.gov/ \\
\hline$M O U_{c}$ & Travel MOU between China and US & $(+)$ & US Department of Commerce, OTTI \& BEA \\
\hline Pop $_{i t}$ & Population in country $i$, in millions of people & $(+)$ & World Economic Fact book \& World Bank \\
\hline$A g e 1_{i t}$ & $\%$ of population between $15-64$ years in country $i$ & $(+)$ & World Economic Fact book \& World Bank \\
\hline$A g e 2_{i t}$ & $\%$ of population over 64 years in $i$ & $(+/-)$ & World Economic Fact book \& World Bank \\
\hline
\end{tabular}

Continued on next page 
Table 11 (continued). Variables Used in the Analysis

\begin{tabular}{|c|c|c|c|}
\hline Urban $_{i t}$ & $\%$ of urban population in $i$ & $(+)$ & World Bank \\
\hline Gender $_{i t}$ & $\%$ of male population in $i$ & $(+/-)$ & World Bank; http://data.worldbank.org/indicator \\
\hline $\operatorname{Leng}_{i}$ & Whether $i$ is English-speaking country & $(+)$ & CIA world fact book \\
\hline $\operatorname{Lspan}_{i}$ & Whether $i$ is Spanish-speaking country & $(+)$ & CIA world fact book \\
\hline Relig $_{i}$ & Whether the majority pop in $i$ is Christian & $(+)$ & CIA world fact book \\
\hline Casus $_{t}$ & \# of fatalities due to terrorist attacks in U.S. & $(-)$ & $\begin{array}{l}\text { The Global Terrorism Database: } \\
\text { https://www.start.umd.edu/gtd/ }\end{array}$ \\
\hline Casorigin $_{i t}$ & \# of fatalities due to terrorist attacks in $i$ & $(-)$ & $\begin{array}{l}\text { The Global Terrorism Database: } \\
\text { https://www.start.umd.edu/gtd/ }\end{array}$ \\
\hline$f f m_{i t}$ & Freedom or foreign movement indicator in $i$ & $(+)$ & University of Gothenburg database \\
\hline$e d d e x_{i t}$ & Education index in $i$ & $(+)$ & University of Gothenburg database \\
\hline$e f d e x_{i t}$ & Economic freedom index in $i$ & $(+)$ & University of Gothenburg database \\
\hline Auto $_{i t}$ & Institutionalized autocracy in $i$ & $(-)$ & University of Gothenburg database \\
\hline Demo $_{i t}$ & Institutionalized democracy in $i$ & $(+)$ & University of Gothenburg database \\
\hline Voiacct $_{i t}$ & Voice and accountability in $i$ & $(+)$ & University of Gothenburg database \\
\hline $\operatorname{Psav}_{t}$ & Political stability \& absence of Violence in the U.S & $(+)$ & University of Gothenburg database \\
\hline Goveff $f_{t}$ & Government effectiveness in the U.S & $(+)$ & University of Gothenburg database \\
\hline Rolaw $_{t}$ & Rule of law in the U.S & $(+)$ & University of Gothenburg database \\
\hline Culdiv $_{i t}$ & Cultural diversity in $\mathrm{i}$ & $(+)$ & University of Gothenburg database \\
\hline Ecorec $_{t}$ & Economic recession in the U.S & $(-)$ & \\
\hline
\end{tabular}




\section{Economic Similarity}

A popular theory in the international trade literature is that the trade volume between two countries tends to be higher when the two countries are more economically alike, having similar per capita incomes (Linder, 1961). This argument is commonly termed the Linder's hypothesis or income similarity model. We model the Linder's hypothesis in two ways; Linderl variable (Linder $\left.1_{i t}\right)$, represented by the absolute value of the difference in per capita real GDP between the U.S. and the origin country, and Linder2 $\left(\right.$ Linder $\left.2_{i t}\right)$, represented by the absolute value of the difference as a ratio of the sum of the per capita real GDP, to determine whether tourism arrivals to the U.S. increase when the origin country is similar economically to the U.S.

\section{Capital Investment}

Investments in infrastructure may improve tourism competitiveness in the destination country. Capital investment in the United States economy (Capinvest) is introduced to estimate its impact on tourism demand.

\subsection{U.S. Government Travel Policies}

\section{Visa Waiver Program}

Visa exemption plays a critical role in international tourists' destination choices. Lyomasa (1983) contends that among many other economic benefits, the visa exemption program helps to promote international travel, facilitate tourism business development, and stimulate the growth of the tourism industry in the destination country. The U.S Visa Waiver Program (VWP), which waives the visa requirement for travelers from certain countries, may greatly improve the attractiveness of the U.S. as a tourist destination and increase the number of visitors from these 
countries. We therefore include a dummy variable $\left(V W P_{i}\right)$ that measures whether a country is a participant of the U.S VWP in the the model to determine its impact on tourist flow to the U.S.

\section{China-U. S Group Leisure Travel Memorandum of Understanding}

The China-U.S. Memorandum of Understanding (MOU) is a policy directive that may influence tourism demand into the U.S. Prior to this MOU, Chinese regulations restrain tourism marketing and group leisure travels to countries without an agreement with the Chinese government known as the Approved Destination Status (ADS) agreement. The signed MOU in 2007 provides the framework that permits group leisure travel from China to the United States. China which was ranked the $17^{\text {th }}$ largest international market for the United States (2006) prior to the MOU is ranked number one largest international market for the U.S. in 2016. The increase in U.S. tourist demand from China may be attributable to the travel MOU. We include the ChinaU.S. MOU dummy variable $\left(M O U_{c}\right)$ to represent the signed MOU agreement between China and the U.S. We expect a positive relationship with international visits from China to the United States.

\subsection{Cultural Factors}

Tourists are more likely to travel to countries with cultural similarities. Earlier work by Vietze (2008) suggests language and religion as proxies for the cultural similarities between two countries. We therefore include a variable indicating English or Spanish-spoken country $\left(\operatorname{Lan}_{i}\right)$ in our analysis. A country is deemed an English or Spanish-speaking country if more than half of the population speaks either English or Spanish. Like language, the religious faith of people in the origin country or the country of destination may influence the decisions of potential tourist. International tourists may be more inclined to visit countries of similar faith. Since most of the 
U.S. population adhere to Christianity, we include a religion variable $\left(\operatorname{Relig}_{i}\right)$ to indicate whether the main religion in the country is Christianity. A value of one is assigned to the religion variable if more than $60 \%$ of the country's population practice the Christian faith.

\subsection{Demographic Factors}

Previous studies have paid little attention to the impact of demographic factors on tourist demand. Here we consider four demographic variables: population, age structure, urbanization rate, and gender. Population $\left(P_{o p} p_{i t}\right)$ has been used in some studies to account for the market size of origin countries - the larger the population in the country of origin, the higher its propensity to generate more tourists (Proenca and Soukiazis, 2005). However, using the population as the only proxy for market size can be problematic since not all individuals in the pool has the same capacity and capability to undertake international trips. To address this problem, an age structure variable between 15-64 years $\left(A g e 1_{i t}\right)$ is introduced into the demand model. This age group are potential income earners and more likely to patronize international tourism services for both business and leisure purposes. We also include the variable for age structure 65 years and above $\left(A g e 2_{i t}\right)$ since individuals in this group may be able to afford the time and money needed for travelling to the U.S but may also be constrained by health considerations.

Another possible proxy for the market size is its urbanization rate $\left(\operatorname{Urban}_{i t}\right)$. Previous studies show that city and urban upbringing may be associated with social stress, anxiety, and mood disorders (e.g., Lederbogen et al. 2011). The physiological stress of living in the city may encourage urban residents to undertake tourism to relax and detach from work (Song et al., 2009). It is also worth noting that the gender composition (Gender ${ }_{i t}$ ) in a country may also affect its potential tourist pools. While the nature of the relationship between gender and international 
tourism demand is difficult to anticipate a priori, some argue that men tend to travel more for business purposes (Song et al., 2009).

\subsection{Governance Indicators}

Tourism is intricately woven into a meshwork of institutions, the rules and norms which influence the behavior and decisions of all the stakeholders, including travelers (Vail and Helt, 2000). As a proxy for quality institutions, we consider several governance indicators, including the

freedom of foreign movement, economic freedom index, education index, political stability and absence of violence, government effectiveness, the rule of law, voice accountability, cultural diversity, institutionalized autocracy, and institutionalized democracy into the model. As can be seen in table 1, a variety of scales are used to measure the governance indicators. Except for the institutionalized autocracy, all other governance indicators are expected to have a positive effect on outbound tourism to the U.S.

\subsection{Incidental Factors}

\section{Terrorist Attacks}

The tourism industry can be greatly affected by certain special events. The September 11, 2001, terrorist attack, for instance, significantly reduced the number of tourists visiting the U.S. due to safety concerns. Any security challenge to life and property can create fear, negatively affecting a tourist' decision to undertake international trips. We therefore construct two measures to account for the impact of terrorist attacks on tourist arrivals to the U.S.: the number of casualties (consisting of the fatalities and injured persons) due to terrorist attacks in both the U.S. ( Casus $_{t}$ ) and the origin country $\left(\right.$ Casorigin $_{i t}$ ). The two terrorist attack variables are expected to negatively affect the international tourism demand for the U.S. in country $i$. 


\section{Economic Recession}

Economic conditions (economic growth or recession) influence consumer expenditure (Stock and Watson, 2003; Malgarini and Margani, 2007). While economic growth may increase tourism demand, an economic recession may produce a contrary result. The 2007 economic recession had a severe impact on the global economy with negative consequences for tourism demand. A dummy variable of economic recession (Ecorec) was incorporated in the model to estimate the effect of economic recession on international travels.

We collect data on the above variables for 27 major tourism generating countries to the U.S. in 1995-2014, including Argentina, Australia, Bahamas, Belgium, Brazil, Canada, China, Colombia, Costa Rica, Dominican Republic, Ecuador, France, Germany, India, Ireland, Israel, Italy, Japan, South Korea, Mexico, the Netherlands, Spain, Sweden, Switzerland, Taiwan, United Kingdom, and Venezuela. Tourists from these 27 countries constitute about $85 \%$ of total inbound travelers to the United States. The annual data used in this study help avoid the potential problem of seasonality in tourism demand.

The core variables used in the analysis are summarized in table 12. Over the nineteen years, inbound travel to the United States increased from 99, 863 to over 23 million. The share of the sum of exports and imports to GDP in the tourist countries of origin on the average far more exceeds that in the U.S., most likely due to the size of its economy. The international market for the U.S. tourism industry represented by the population is about 129 million on average per year. While 66 percent of the overall population is between the ages of 15 and 64 years, the proportion of male and female are almost equal (49.6\% being the proportion of male). Majority of the population $(72.25 \%)$ live in urban areas of the countries of origin. 
Table 12. Summary Statistics of Core Variables Used in the Analysis

\begin{tabular}{|c|c|c|c|c|c|}
\hline VARIABLES & $\mathbf{N}$ & Mean & Standard deviation & Min & Max \\
\hline Tourists arrivals (thousands) & 513 & 1817 & 3891 & 99.863 & 23410 \\
\hline Real GDP in originating countries (millions) & 513 & 1194000 & 1426000 & 7.302 & 8333000 \\
\hline Real GDP in the US (billions) & 513 & 13860 & 1582 & 10690 & 16180 \\
\hline Relative cost of living in the US & 513 & 1.604 & 4.228 & 0.212 & 35.73 \\
\hline Substitute price in Canada & 513 & 0.925 & 0.115 & 0.753 & 1.141 \\
\hline Substitute price in Mexico & 513 & 0.674 & 0.0949 & 0.493 & 0.850 \\
\hline Distance & 513 & 6,821 & 3,613 & 732.4 & 15,937 \\
\hline Real REER & 513 & 1.116 & 0.213 & 0.490 & 2.170 \\
\hline Travel cost (hundreds) & 513 & 4444.95 & 3516.58 & 137.13 & 18920 \\
\hline Trade openness in US & 513 & 0.00554 & 0.00825 & $8.30 \mathrm{e}-05$ & 0.0408 \\
\hline Trade openness in originating countries & 513 & 6,206 & 32,190 & 0.00918 & 222,677 \\
\hline Population in originating countries (millions) & 513 & 129.1 & 313.2 & 0.0283790 & 1364 \\
\hline Proportion of population between ages $15-64 \mathrm{yrs}$ & 513 & 66.07 & 3.280 & 58.65 & 74.35 \\
\hline Proportion of population over $64 \mathrm{yrs}$ & 513 & 10.28 & 5.623 & 2.754 & 22.01 \\
\hline Proportion of male population & 513 & 49.60 & 0.763 & 48.50 & 51.86 \\
\hline Proportion of urban population & 513 & 75.25 & 14.60 & 26.82 & 97.82 \\
\hline Casualties from terrorist attacks in originating countries & 513 & 25.59 & 123.1 & 0 & 2,002 \\
\hline Casualties from terrorist attacks in the US & 513 & 984.4 & 3,985 & 0 & 17,870 \\
\hline Linder effect 1 & 513 & 21,476 & 14,601 & 128.8 & 52,966 \\
\hline Linder effect 2 & 513 & 0.405 & 0.326 & -0.0115 & 0.975 \\
\hline Cultural diversity & 513 & 0.204 & 0.189 & $1.00 \mathrm{e}-04$ & 0.666 \\
\hline Voice and accountability & 513 & 0.950 & 0.509 & -0.0800 & 1.750 \\
\hline Capital investment & 513 & 141.8 & 25.09 & 91.44 & 192.2 \\
\hline Education index & 513 & 0.723 & 0.137 & 0.348 & 0.932 \\
\hline Freedom of foreign movement & 513 & 1.758 & 0.491 & 0 & 2 \\
\hline Autocracy & 513 & 1.246 & 1.160 & 1 & 7 \\
\hline Democracy & 513 & 8.600 & 2.122 & 1 & 10 \\
\hline Economic freedom index & 513 & 66.10 & 9.327 & 36.10 & 83.10 \\
\hline Political stability \& absence of violence & 513 & 0.530 & 0.340 & -0.200 & 1.010 \\
\hline Government effectiveness & 513 & 1.646 & 0.123 & 1.460 & 1.840 \\
\hline Rule of law & 513 & 1.550 & 0.0578 & 1.430 & 1.630 \\
\hline
\end{tabular}




\section{Estimation Results}

We first estimate the pooled, fixed effect, and random effect models. The pooled model assumes homogeneity of individual countries, while the fixed and random effects models incorporate heterogeneity in the estimation process. The results of two preliminary test to determine the appropriate model is shown in table A1 in the appendix. The Breusch and Pagan Lagrange Multiplier test rejects the hypothesis of zero variances across entities and favors the random effect model, while the Hausman test rejects the hypothesis that the unobserved individual effects (in the error term) are not correlated with the regressors, in favor of the fixed effect model.

We employ the modified Wald test for group-wise heteroscedasticity and the Wooldridge test for autocorrelation to check for the presence of heteroscedasticity and serial correlation, respectively. The results in table A2 in the appendix indicate the presence of heteroscedasticity and serial correlation, as well as cross-sectional dependence in the fixed effects model that may bias the estimated coefficients. While a panel fixed effect approach with robust standard errors address the heteroscedasticity problem, the problems of cross-sectional dependence and serial correlation remain unresolved. Additionally, the heteroscedasticity problem further leads to the endogeneity problem if the error term enters the model in its multiplicative form, as in equations (2) and (3). To correct for these problems, we use the Poisson Pseudo Maximum Likelihood (PPML) approach that employs the Poisson techniques to estimate the fixed effects gravity model.

The estimation results for the basic and the augmented models with the economy and government policy variables using the PPML approach is presented in table 13. In the basic model, all the variables are significant except for economic recession, and have the expected signs except for real GDP in the U.S. Tourist flows to the U.S. are negatively affected by the distance between source countries and the U.S. and the real effective exchange rate of the US dollars. The incidental factor such as the economic recession has the expected negative sign but is not significant. The 
basic gravity model suggests that the distance and sizes of the economies of the origin countries and the U.S. do influence tourism demand.

Table 13. Basic and Augmented Gravity Model with Economic, Incidental and Government Policy Factors

\begin{tabular}{|c|c|c|c|c|c|}
\hline Variables & $\begin{array}{c}\text { (Model 1a) } \\
\text { Basic gravity }\end{array}$ & $\begin{array}{c}\text { (Model 1b) } \\
\text { Augmented } \\
\end{array}$ & $\begin{array}{c}\text { (Model 1c) } \\
\text { Augmented } \\
\end{array}$ & $\begin{array}{c}\text { (Model 1d) } \\
\text { Augmented } \\
\end{array}$ & $\begin{array}{l}\text { (Model 1e) } \\
\text { Augmented }\end{array}$ \\
\hline lnRGDP-O & $\begin{array}{c}0.645^{* * * *} \\
(0.0323)\end{array}$ & $\begin{array}{c}0.681 * * * \\
(0.0418)\end{array}$ & $\begin{array}{l}-0.00526 \\
(0.0295)\end{array}$ & $\begin{array}{c}0.0811 * * * \\
(0.0114)\end{array}$ & $\begin{array}{c}0.000779 \\
(0.0289)\end{array}$ \\
\hline lnRGDP-US & $\begin{array}{c}-0.726^{*} \\
(0.406)\end{array}$ & $\begin{array}{c}4.458 * * * \\
(0.495)\end{array}$ & $\begin{array}{c}-0.986^{* * * *} \\
(0.215)\end{array}$ & $\begin{array}{c}0.594 * * \\
(0.273)\end{array}$ & $\begin{array}{c}0.859 * * * \\
(0.238)\end{array}$ \\
\hline lnDist & $\begin{array}{c}-1.211 * * * \\
(0.0274)\end{array}$ & & $\begin{array}{c}-0.452 * * * \\
(0.0497)\end{array}$ & & \\
\hline lnREER & $\begin{array}{c}-1.599 * * * \\
(0.226)\end{array}$ & $\begin{array}{c}-2.292 * * * \\
(0.355)\end{array}$ & $\begin{array}{c}-1.551 * * * \\
(0.185)\end{array}$ & $\begin{array}{c}-1.688^{* * * *} \\
(0.205)\end{array}$ & $\begin{array}{c}-1.852 * * * \\
(0.202)\end{array}$ \\
\hline $\ln R P$ & & $\begin{array}{l}-0.150 \\
(0.193)\end{array}$ & $\begin{array}{c}-0.309^{* * * *} \\
(0.0880)\end{array}$ & & $\begin{array}{c}-0.297 * * * \\
(0.0867)\end{array}$ \\
\hline $\ln T R_{t}^{i \rightarrow U S}$ & & & $\begin{array}{l}1.066^{* * *} * \\
(0.0426)\end{array}$ & $\begin{array}{c}0.986 * * * \\
(0.0292)\end{array}$ & $\begin{array}{l}1.068 * * * \\
(0.0433)\end{array}$ \\
\hline VWP & & & $\begin{array}{c}0.345^{* * * *} \\
(0.123)\end{array}$ & $\begin{array}{l}-0.00266 \\
(0.0888)\end{array}$ & $\begin{array}{c}0.329 * * * \\
(0.120)\end{array}$ \\
\hline MOU & & & $\begin{array}{c}-1.938 * * * \\
(0.173)\end{array}$ & $\begin{array}{c}-1.999 * * * \\
(0.167)\end{array}$ & $\begin{array}{c}-1.931 * * * \\
(0.159)\end{array}$ \\
\hline Ecorec & $\begin{array}{l}-0.0775 \\
(0.225)\end{array}$ & $\begin{array}{c}0.253 \\
(0.221)\end{array}$ & $\begin{array}{l}-0.141 \\
(0.114)\end{array}$ & $\begin{array}{r}-0.0134 \\
(0.131)\end{array}$ & $\begin{array}{c}-0.0250 \\
(0.115)\end{array}$ \\
\hline $\operatorname{lnTC}$ & & $\begin{array}{c}-1.241 * * * \\
(0.0405)\end{array}$ & & $\begin{array}{c}-0.406 * * * \\
(0.0530)\end{array}$ & $\begin{array}{c}-0.463 * * * \\
(0.0486)\end{array}$ \\
\hline Constant & $\begin{array}{c}28.96 * * \\
(12.23)\end{array}$ & $\begin{array}{c}-123.6^{* * * *} \\
(15.02)\end{array}$ & $\begin{array}{c}53.59 * * * \\
(6.753)\end{array}$ & $\begin{array}{c}4.490 \\
(7.872)\end{array}$ & $\begin{array}{l}-0.395 \\
(6.894)\end{array}$ \\
\hline R-squared & 0.732 & 0.729 & 0.926 & 0.919 & 0.935 \\
\hline
\end{tabular}

The basic gravity model (model 1 ) in table 13 is augmented with additional variables to examine the effects of other economic factors and some government policies on tourism demand. These variables were not all run simultaneously in one model since some of them were highly correlated. The real GDP of the U.S. regains its expected signs and remain significant in the augmented models 1b, 1d, and 1e. Government policies affect the decision of international tourist to travel to the United States. The visa waiver program in the U.S. is positive and significant in models 1c and 1e, suggesting that the program enhances tourist travel to the United States. The 
China-U.S. group leisure memorandum of understanding significantly affects tourism demand but has an unexpected negative sign. However, it regained the expected sign when demographic, cultural, and governance indicators are controlled for in model $5 \mathrm{~d}$ of table 17 . This suggests that the MOU increases tourist flow to the U.S.

Economic factors, such as the relative cost of living, travel cost, and trade openness in the U.S. are significant and possess the expected signs. The results of the augmented models $1 \mathrm{~b}$ and 1d of table 13 show that travel cost significantly influences the decision of tourist to travel to the United States. The high coefficient of travel cost in model $1 \mathrm{~b}$ suggests that tourists are very sensitive to the cost of travel to the U.S. Therefore, tourism demand in the U.S. reduces as the cost of travel increases. Similarly, the relative cost of living in the U.S. negatively affect demand for tourism goods and services. As shown in models 1c and 1e, international tourists flow to the U.S. declines with the increasing relative cost of goods and services in the U.S. We also observed that trade relations between origin countries and the U.S. are a significant determinant of inbound tourism to the U.S. The estimated coefficients of trade openness between the source countries and the U.S. as a proportion of the source and destination countries are positive and significant, as shown in tables 13 and 14, respectively. This suggests that tourist flow to the U.S. is enhanced with increasing trade between originating countries and the United States.

International tourist decisions to travel to the U.S. could be influenced by relative prices of goods and services in competing destinations. The estimated coefficients show that the competitive prices between the U.S., Canada, and Mexico have a negative and significant effect on U.S. tourism demand. An increased price of tourism goods and services in the U.S. relative to those in Canada and Mexico will reduce tourist flows to the United States. Results in table 14 also provide evidence of the Linder hypothesis. The estimated coefficients of linder1 and linder2 are negative 
and significant albeit relatively small for linder1. Tourism flow is inversely related to the difference in the per capita income between the source and destination country, implying that inbound tourism to the U.S. increases as the per capita income similarity converge.

The model is further augmented with demographic and cultural factors to examine their impact on inbound tourism to the U.S. Results of models $2 \mathrm{a}-\mathrm{d}$ of table 14 , and model $3 \mathrm{~b}$ of table 15 provide evidence that cultural factors influence tourism arrivals to the U.S. Language and religion have a significant effect on the decisions of tourists to travel to the U.S. While the estimated coefficients of English and Spanish language speaking source countries have positive signs, other languages possess a negative sign. Similarly, the estimated coefficient of the Christian religion is positive while other religions have a negative sign. This suggests that tourists from majorly English and/or Spanish speaking source countries are more likely to travel to the United States while those that speak languages other than English and/or Spanish. Also, predominantly Christian countries tend to patronize U.S. tourism goods and services than countries of other faith.

Table 15 reveals that demographic factors are significant determinants of inbound tourism to the U.S., though some possess unexpected signs. The total population, the percentage of populations age between 15-64 years, 64 years and above, and the percentage of male populations all have a significant but negative impact on tourist travel to the United States. These suggest that increasing percentage of male populations, the percentage of populations age between 15-64 years and above 64 years, and the total population reduce tourist inbound to the United States. This is a rather strange result though earlier studies obtained similar results for the effect of the population (Deluna and Joen, 2014). However, the percentage of population living in urban centers have a positive and significant effect on tourism demand. This suggests that people in urban communities are more likely to travel to the United States for tourism purposes. 
Table 14. Augmented Gravity Model with Economic, Cultural Factors and Linder Effects

\begin{tabular}{|c|c|c|c|c|c|c|}
\hline Variables & (Model 2a) & (Model 2b) & (Model 2c) & (Model 2d) & (Model 2e) & (Model 2f) \\
\hline \multirow[t]{2}{*}{$\operatorname{lnRGDP-O}$} & $0.590 * * *$ & 0.201 & $0.925 * * *$ & $0.576 * *$ & $1.296 * * *$ & $1.041 * * *$ \\
\hline & $(0.215)$ & $(0.226)$ & $(0.235)$ & $(0.262)$ & $(0.270)$ & $(0.298)$ \\
\hline \multirow[t]{2}{*}{ lnDist } & $-0.152 * * *$ & $-0.101 * *$ & $-0.0991 * *$ & $-0.0786^{*}$ & $-0.118 * * *$ & $-0.0988 * *$ \\
\hline & $(0.0463)$ & $(0.0447)$ & $(0.0411)$ & $(0.0427)$ & $(0.0421)$ & $(0.0428)$ \\
\hline \multirow[t]{2}{*}{ InREER } & $-0.917 * * *$ & $-0.822 * * *$ & $-0.509 * * *$ & $-0.462 * * *$ & $-0.856^{* * *}$ & $-0.817 * * *$ \\
\hline & $(0.114)$ & $(0.109)$ & $(0.0904)$ & $(0.0914)$ & $(0.110)$ & $(0.108)$ \\
\hline \multirow[t]{2}{*}{ lnSPCan } & $-1.026 * * *$ & $-0.984 * * *$ & & & $-0.899 * * *$ & $-0.893 * * *$ \\
\hline & $(0.176)$ & $(0.166)$ & & & $(0.176)$ & $(0.173)$ \\
\hline \multirow{2}{*}{$\ln T R_{t}^{i \rightarrow U S}$} & $0.544 * * *$ & $0.820 * * *$ & 0.263 & $0.519 * *$ & -0.0435 & 0.143 \\
\hline & $(0.183)$ & $(0.187)$ & $(0.200)$ & $(0.216)$ & $(0.228)$ & $(0.245)$ \\
\hline \multirow{2}{*}{$\ln T R_{t}^{U S \rightarrow i}$} & $0.380 * *$ & 0.0890 & $0.641 * * *$ & $0.378 *$ & $0.920 * * *$ & $0.728 * * *$ \\
\hline & $(0.163)$ & $(0.171)$ & $(0.179)$ & $(0.198)$ & $(0.205)$ & $(0.226)$ \\
\hline \multirow[t]{2}{*}{$\operatorname{lnPop}$} & -0.0533 & 0.0625 & $-0.0902 *$ & 0.00251 & $-0.151 * * *$ & -0.0823 \\
\hline & $(0.0475)$ & $(0.0503)$ & $(0.0503)$ & $(0.0562)$ & $(0.0549)$ & $(0.0615)$ \\
\hline \multirow[t]{2}{*}{ Linder1 } & $-7.12 \mathrm{e}-06^{* * *}$ & & $-6.82 \mathrm{e}-06 * * *$ & & $-4.25 \mathrm{e}-06^{*}$ & \\
\hline & $(2.56 \mathrm{e}-06)$ & & $(2.47 \mathrm{e}-06)$ & & $(2.47 \mathrm{e}-06)$ & \\
\hline \multirow[t]{2}{*}{ Leng } & $0.730 * * *$ & $0.712 * * *$ & $0.770 * * *$ & $0.757 * * *$ & $0.764 * * *$ & $0.753 * * *$ \\
\hline & $(0.0450)$ & $(0.0463)$ & $(0.0456)$ & $(0.0463)$ & $(0.0418)$ & $(0.0429)$ \\
\hline \multirow[t]{2}{*}{ Lspan } & $1.168 * * *$ & $1.229 * * *$ & $1.246 * * *$ & $1.271 * * *$ & $1.237 * * *$ & $1.260 * * *$ \\
\hline & $(0.0839)$ & $(0.0872)$ & $(0.0806)$ & $(0.0868)$ & $(0.0792)$ & $(0.0826)$ \\
\hline \multirow[t]{2}{*}{ Relig } & 0.0246 & 0.0802 & 0.0454 & 0.0735 & 0.0293 & 0.0548 \\
\hline & $(0.0772)$ & $(0.0826)$ & $(0.0702)$ & $(0.0735)$ & $(0.0699)$ & $(0.0741)$ \\
\hline \multirow[t]{2}{*}{ VWP } & -0.0263 & $-0.190 *$ & -0.110 & $-0.189 * *$ & $-0.186^{* *}$ & $-0.253 * * *$ \\
\hline & $(0.0901)$ & $(0.0989)$ & $(0.0824)$ & $(0.0863)$ & $(0.0884)$ & $(0.0907)$ \\
\hline \multirow[t]{2}{*}{ MOU } & $-1.461 * * *$ & $-1.432 * * *$ & $-1.525 * * *$ & $-1.515^{* * *}$ & $-1.544 * * *$ & $-1.530 * * *$ \\
\hline & $(0.178)$ & $(0.175)$ & $(0.171)$ & $(0.170)$ & $(0.155)$ & $(0.155)$ \\
\hline \multirow[t]{2}{*}{ Ecorec } & $-0.232 * * *$ & $-0.230 * * *$ & $-0.206^{* * *}$ & $-0.200 * * *$ & $-0.284 * * *$ & $-0.279 * * *$ \\
\hline & $(0.0608)$ & $(0.0603)$ & $(0.0570)$ & $(0.0554)$ & $(0.0611)$ & $(0.0604)$ \\
\hline \multirow[t]{2}{*}{ Linder2 } & & $-0.917 * * *$ & & $-0.707 * * *$ & & $-0.501 * *$ \\
\hline & & $(0.215)$ & & $(0.203)$ & & $(0.196)$ \\
\hline \multirow[t]{2}{*}{ lnSPMex } & & & $-0.973 * * *$ & $-0.896 * * *$ & $-0.884 * * *$ & $-0.824 * * *$ \\
\hline & & & $(0.190)$ & $(0.189)$ & $(0.188)$ & $(0.190)$ \\
\hline Constant & 3.737 & $12.89 * *$ & -6.479 & 2.168 & $-16.38 * *$ & -10.11 \\
\hline R-squared & 0.973 & 0.974 & 0.972 & 0.972 & 0.973 & 0.973 \\
\hline
\end{tabular}

Notes: Standard errors in brackets. $* * *, * *$ and $*$ denotes significance at $1 \%, 5 \%$, and $10 \%$ level, respectively. 
Table 15. Augmented Gravity Model with Demographic and Cultural factors)

\begin{tabular}{|c|c|c|c|c|c|}
\hline Variables & Model 3a & Model 3b & Model 3c & Model 3d & Model 3e \\
\hline $\operatorname{lnRGDP-O}$ & $\begin{array}{c}2.421 * * * \\
(0.309)\end{array}$ & $\begin{array}{c}1.725 * * * \\
(0.186)\end{array}$ & $\begin{array}{c}0.651 * * * \\
(0.147)\end{array}$ & $\begin{array}{c}1.138 * * * \\
(0.134)\end{array}$ & $\begin{array}{c}1.736 * * * \\
(0.186)\end{array}$ \\
\hline lnRGDP-US & $\begin{array}{c}-2.121 * * * \\
(0.334)\end{array}$ & $\begin{array}{c}-0.971 * * * \\
(0.227)\end{array}$ & $\begin{array}{c}-0.427 * \\
(0.246)\end{array}$ & $\begin{array}{c}-1.214 * * * \\
(0.218)\end{array}$ & $\begin{array}{c}-0.994 * * * \\
(0.216)\end{array}$ \\
\hline $\operatorname{lnDist}$ & $\begin{array}{c}-0.0806^{*} \\
(0.0447)\end{array}$ & $\begin{array}{c}-0.499 * * * \\
(0.0612)\end{array}$ & $\begin{array}{c}-0.103 * * \\
(0.0413)\end{array}$ & $\begin{array}{c}-0.200 * * * \\
(0.0379)\end{array}$ & $\begin{array}{c}-0.509 * * * \\
(0.0605)\end{array}$ \\
\hline lnREER & $\begin{array}{c}-1.039 * * * \\
(0.104)\end{array}$ & $\begin{array}{c}-0.885^{* * * *} \\
(0.0882)\end{array}$ & $\begin{array}{c}-0.810^{* * *} \\
(0.0827)\end{array}$ & $\begin{array}{c}-0.899 * * * \\
(0.0807)\end{array}$ & $\begin{array}{c}-0.885 * * * \\
(0.0876)\end{array}$ \\
\hline lnSPCan & $\begin{array}{c}-0.516^{* * *} \\
(0.148)\end{array}$ & $\begin{array}{c}-0.300^{* *} \\
(0.141)\end{array}$ & $\begin{array}{c}-0.359^{* *} \\
(0.142)\end{array}$ & $\begin{array}{c}-0.478 * * * \\
(0.130)\end{array}$ & $\begin{array}{c}-0.302 * * \\
(0.139)\end{array}$ \\
\hline lnSPMex & $\begin{array}{c}-0.370^{* *} \\
(0.183)\end{array}$ & $\begin{array}{c}-0.445^{* * *} \\
(0.152)\end{array}$ & $\begin{array}{c}-0.366^{* *} \\
(0.166)\end{array}$ & $\begin{array}{c}-0.292^{*} \\
(0.165)\end{array}$ & $\begin{array}{c}-0.442 * * * \\
(0.151)\end{array}$ \\
\hline $\ln T R_{t}^{i \rightarrow U S}$ & $\begin{array}{c}-0.967 * * * \\
(0.254)\end{array}$ & $\begin{array}{c}-0.601 * * * \\
(0.178)\end{array}$ & $\begin{array}{c}0.443 * * * \\
(0.137)\end{array}$ & $\begin{array}{c}0.00295 \\
(0.127)\end{array}$ & $\begin{array}{c}-0.613^{* * *} \\
(0.179)\end{array}$ \\
\hline $\ln T R_{t}^{U S \rightarrow i}$ & $\begin{array}{c}1.776^{* * * *} \\
(0.234)\end{array}$ & $\begin{array}{c}1.340 * * * \\
(0.150)\end{array}$ & $\begin{array}{c}0.461 * * * \\
(0.111)\end{array}$ & $\begin{array}{c}0.820^{* * *} \\
(0.103)\end{array}$ & $\begin{array}{c}1.348^{* * *} \\
(0.150)\end{array}$ \\
\hline lnAge1 & & $\begin{array}{c}-3.558^{* * * *} \\
(0.518)\end{array}$ & & & $\begin{array}{c}-3.488 * * * \\
(0.527)\end{array}$ \\
\hline lnAge2 & & $\begin{array}{c}-0.445^{* * *} * \\
(0.0831)\end{array}$ & & & $\begin{array}{c}-0.428 * * * \\
(0.0774)\end{array}$ \\
\hline Leng & $\begin{array}{c}0.787 * * * \\
(0.0377)\end{array}$ & $\begin{array}{c}0.855 * * * \\
(0.0327)\end{array}$ & $\begin{array}{c}0.900 * * * \\
(0.0424)\end{array}$ & $\begin{array}{c}0.811 * * * \\
(0.0326)\end{array}$ & \\
\hline Lspan & $\begin{array}{l}1.343 * * * \\
(0.0827)\end{array}$ & $\begin{array}{c}0.815 * * * \\
(0.0537)\end{array}$ & $\begin{array}{l}1.059 * * * \\
(0.0465)\end{array}$ & $\begin{array}{l}1.106^{* * *} \\
(0.0518)\end{array}$ & \\
\hline Relig & $\begin{array}{c}0.0477 \\
(0.0686)\end{array}$ & $\begin{array}{c}0.448 * * * \\
(0.136)\end{array}$ & $\begin{array}{l}-0.0526 \\
(0.0504)\end{array}$ & $\begin{array}{l}-0.0105 \\
(0.0525)\end{array}$ & \\
\hline Casorigin & $\begin{array}{l}-8.91 \mathrm{e}-05 \\
(0.000169)\end{array}$ & $\begin{array}{l}-3.46 \mathrm{e}-05 \\
(0.000111)\end{array}$ & $\begin{array}{l}-0.000131 \\
(0.000171)\end{array}$ & $\begin{array}{c}-6.34 \mathrm{e}-05 \\
(0.000146)\end{array}$ & $\begin{array}{c}-4.20 \mathrm{e}-05 \\
(0.000114)\end{array}$ \\
\hline Casus & $\begin{array}{c}3.40 \mathrm{e}-06 \\
(2.35 \mathrm{e}-06)\end{array}$ & $\begin{array}{c}2.86 \mathrm{e}-06 \\
(2.69 \mathrm{e}-06)\end{array}$ & $\begin{array}{c}2.63 \mathrm{e}-06 \\
(2.06 \mathrm{e}-06)\end{array}$ & $\begin{array}{c}2.75 \mathrm{e}-06 \\
(1.79 \mathrm{e}-06)\end{array}$ & $\begin{array}{c}2.85 \mathrm{e}-06 \\
(2.70 \mathrm{e}-06)\end{array}$ \\
\hline VWP & $\begin{array}{c}-0.436 * * * \\
(0.0922)\end{array}$ & $\begin{array}{c}0.327 * * * \\
(0.0980)\end{array}$ & $\begin{array}{c}-0.350 * * * \\
(0.0635)\end{array}$ & $\begin{array}{c}-0.123 * * \\
(0.0612)\end{array}$ & $\begin{array}{c}0.332 * * * \\
(0.0973)\end{array}$ \\
\hline MOU & $\begin{array}{c}-1.525^{* * *} \\
(0.154)\end{array}$ & $\begin{array}{c}-1.171 * * * \\
(0.167)\end{array}$ & $\begin{array}{c}-1.009 * * * \\
(0.209)\end{array}$ & $\begin{array}{c}-1.303^{* * *} \\
(0.171)\end{array}$ & $\begin{array}{c}-1.168 * * * \\
(0.167)\end{array}$ \\
\hline Ecorec & $\begin{array}{c}-0.177 * * * \\
(0.0566)\end{array}$ & $\begin{array}{c}-0.159 * * * \\
(0.0455)\end{array}$ & $\begin{array}{c}-0.157 * * * \\
(0.0502)\end{array}$ & $\begin{array}{c}-0.158 * * * \\
(0.0488)\end{array}$ & $\begin{array}{c}-0.158 * * * \\
(0.0448)\end{array}$ \\
\hline $\operatorname{lnPop}$ & $\begin{array}{c}-0.317 * * * \\
(0.0647)\end{array}$ & & & & \\
\hline lnGender & & & $\begin{array}{c}-23.61 * * * \\
(3.428)\end{array}$ & & \\
\hline lnUrban & & & & $\begin{array}{c}1.287 * * * \\
(0.210)\end{array}$ & \\
\hline Loth & & & & & $\begin{array}{c}-0.842 * * * \\
(0.0322)\end{array}$ \\
\hline Roth & & & & & $\begin{array}{c}-0.416 * * * \\
(0.125)\end{array}$ \\
\hline Constant & $\begin{array}{c}16.96^{* *} \\
(7.434) \\
\end{array}$ & $\begin{array}{c}15.37 * * \\
(7.683) \\
\end{array}$ & $\begin{array}{c}105.3 * * * \\
(14.76)\end{array}$ & $\begin{array}{c}17.38 * * * \\
(6.618)\end{array}$ & $\begin{array}{c}16.75 * * \\
(7.525) \\
\end{array}$ \\
\hline R-squared & 0.981 & 0.985 & 0.983 & 0.985 & 0.985 \\
\hline
\end{tabular}


Table 16. Augmented gravity model (Capital investment and Terrorist attack)

\begin{tabular}{|c|c|c|}
\hline Variables & Model 4a & Model 4b \\
\hline \multirow[t]{2}{*}{$\operatorname{lnRGDP-O}$} & $1.156^{* * *}$ & $1.171 * * *$ \\
\hline & $(0.0262)$ & $(0.0564)$ \\
\hline \multirow[t]{2}{*}{$\operatorname{lnDist}$} & $-0.210 * * *$ & -0.0956 \\
\hline & $(0.0404)$ & $(0.0686)$ \\
\hline \multirow[t]{2}{*}{ InREER } & $-0.875 * * *$ & $-0.930 * * *$ \\
\hline & $(0.0895)$ & $(0.158)$ \\
\hline \multirow[t]{2}{*}{$\ln$ Pop } & -0.0106 & 0.0753 \\
\hline & $(0.0213)$ & $(0.0637)$ \\
\hline \multirow[t]{2}{*}{$\operatorname{lnSPCan}$} & $-0.868 * * *$ & $-0.583 * *$ \\
\hline & $(0.156)$ & $(0.238)$ \\
\hline \multirow[t]{2}{*}{$\operatorname{lnSPMex}$} & $-0.811 * * *$ & $-1.448 * * *$ \\
\hline & $(0.151)$ & $(0.286)$ \\
\hline \multirow{2}{*}{$\ln T R_{t}^{U S \rightarrow i}$} & $0.817 * * *$ & $0.831 * * *$ \\
\hline & $(0.0200)$ & $(0.0401)$ \\
\hline \multirow[t]{2}{*}{ lnCapinvest } & $0.00172 *$ & $0.00700^{* * *}$ \\
\hline & $(0.00104)$ & $(0.00230)$ \\
\hline \multirow[t]{2}{*}{ Leng } & $0.850 * * *$ & $0.907 * * *$ \\
\hline & $(0.0351)$ & $(0.0604)$ \\
\hline \multirow[t]{2}{*}{ Lspan } & $0.842^{* * *}$ & $0.744 * * *$ \\
\hline & $(0.0630)$ & $(0.0818)$ \\
\hline \multirow[t]{2}{*}{ Relig } & $-0.0866^{*}$ & 0.166 \\
\hline & $(0.0498)$ & $(0.117)$ \\
\hline \multirow[t]{2}{*}{ VWP } & $-0.118 *$ & $-0.298 * * *$ \\
\hline & $(0.0630)$ & $(0.105)$ \\
\hline \multirow[t]{2}{*}{ MOU } & 0.124 & -0.0923 \\
\hline & $(0.192)$ & $(0.247)$ \\
\hline \multirow[t]{2}{*}{ Ecorec } & $-0.342 * * *$ & $-0.500 * * *$ \\
\hline & $(0.0654)$ & $(0.124)$ \\
\hline \multirow[t]{2}{*}{$\operatorname{lnVoiacct}$} & $-0.126^{* * *}$ & $-0.0837 *$ \\
\hline & $(0.0388)$ & $(0.0489)$ \\
\hline \multirow[t]{2}{*}{$\ln$ Auto } & $-1.050 * * *$ & $-1.035 * * *$ \\
\hline & $(0.104)$ & $(0.185)$ \\
\hline \multirow[t]{2}{*}{ lnRolaw } & $-0.986^{*}$ & $-2.448 * *$ \\
\hline & $(0.535)$ & (1.057) \\
\hline \multirow[t]{2}{*}{$\operatorname{lnCasorigin}$} & & $-0.0304 * *$ \\
\hline & & $(0.0147)$ \\
\hline \multirow[t]{2}{*}{ lnCasus } & & 0.00808 \\
\hline & & (0.00922) \\
\hline \multirow[t]{2}{*}{ Constant } & $-13.95 * * *$ & $-17.28 * * *$ \\
\hline & $(0.903)$ & $(1.425)$ \\
\hline Observations & 509 & 171 \\
\hline R-squared & 0.980 & 0.986 \\
\hline
\end{tabular}

Notes: Standard errors in brackets. ${ }^{* * *}, * *$ and $*$ denotes significance at $1 \%, 5 \%$, and $10 \%$ levels, respectively.

A dummy variable for economic recession has the expected negative sign in both basic and augmented models but is insignificant in the former. However, when control for demographic and 
cultural factors in table 15, economic recession regains its significance for all the models (3a-d). This suggests that incidental factors such as a sudden recession in the economy are a negative and significant determinant of tourism demand.

Model $4 \mathrm{~b}$ in table 16 show that tourism demand in the U.S. is significantly affected by casualties from terrorist attacks, and capital investment in the tourism industry. Though casualties resulting from a terrorist attack in the U.S. did not affect tourism demand, casualties in the origin countries significantly depress tourist flow to the U.S.- tourist flow to the U.S. reduces by $0.03 \%$ for a $1 \%$ percent increase in casualties from a terrorist attack in the source countries. Investment in tourism-related infrastructure has a positive and significant impact on international tourist travel decision. The estimated coefficient suggests that for a $1 \%$ increase in capital investment, U.S inbound tourist flow will increase by $0.007 \%$.

The nature of institutions and governance systems in the source and destination countries may be relevant in tourist travel decisions. Incorporating governance indicators into the gravity model, the results from table 17 show that political stability and absence of violence, government effectiveness, and the rule of law have the expected signs but not significant. When controlled for capital investment and Linder effect (economic similarity) however in model 6a in table 18, political stability and absence of violence and government effectiveness becomes a significant determinant of inbound tourism in the United States. Freedom for foreign movement, economic freedom, institutionalized autocracy and democracies are significant and have the expected signs. This suggests that freedom for foreign movement, economic freedom, and institutionalized democracies enhance tourists flow to the U.S., while institutionalized autocracy reduces tourism demand. Voice accountability and cultural diversity are significant but negatively influence tourist arrival in the United States. Furthermore, the educational index as a proxy for the level of education 
is a positive and significant determinant of tourists flow into the United States. This suggests that a more educated populace is more likely to travel to the United States for tourism purposes.

The effect of habit persistence or word-of-mouth, and performances of previous economies in originating and destination countries on decision making of international tourists were examined using a dynamic panel model recommended by Arellano and Bover (1995). The estimated results for one-step and two-step systems GMM dynamic model is shown in table 19. Models 6a-b and 6c-d are one-step and two-step systems GMM respectively that are instrumented with lags up to two. The models 6e-f are two-step system GMM instrumented with lags from three to seven were used to validate the specification of the other models. The estimated coefficients of the variables in models 6e-f are very similar to those of models 6a-d. The autocorrelation 2 (AR2) test of all the models indicate the absence of autocorrelations, and the Sargan and Hansen test of overidentifying restrictions failed to reject the hypothesis that the instruments as a group are exogenous.

Furthermore, the joint significance of the Wald test suggests that our model is satisfactory. The dynamic model also provides the additional advantage of estimating the long-run elasticities by transforming the estimated short-run coefficients by $\left(1-\beta_{1}\right)$, which are indicated below in table 18. Generally, the estimators have the expected signs except for the economic recession variable. The lagged dependable variable in all the models are positive and significant. Similarly, the lagged real GDP of the countries of origin are significant but negative in all the models. The lagged real GDP of the destination country (United States) is however negative and significant in only model 6e. This suggest that previous real GDP of source and destination countries do influence tourist decision to travel to the United States albeit negatively. The significance of the lagged dependent variable suggests that its omission from the model may result in the over estimation of the other variables. 
Table 17. Augmented Gravity Model with Governance Indicators

\begin{tabular}{|c|c|c|c|c|c|c|}
\hline Variables & Model 5a & Model 5b & Model 5c & Model 5d & Model 5e & Model 5f \\
\hline lnRGDP-O & $\begin{array}{c}1.410 * * * \\
(0.136)\end{array}$ & $\begin{array}{c}1.673 * * * \\
(0.164)\end{array}$ & $\begin{array}{c}1.606 * * * \\
(0.159)\end{array}$ & $\begin{array}{c}0.254 * * * \\
(0.0202)\end{array}$ & $\begin{array}{c}0.300 * * * \\
(0.0227)\end{array}$ & $\begin{array}{c}0.218 * * * \\
(0.0216)\end{array}$ \\
\hline lnRGDP-US & $\begin{array}{c}-1.367 * * * \\
(0.408)\end{array}$ & $\begin{array}{c}-1.368 * * * \\
(0.438)\end{array}$ & $\begin{array}{c}-1.436 * * * \\
(0.262)\end{array}$ & $\begin{array}{c}0.244 \\
(0.404)\end{array}$ & $\begin{array}{c}0.602 \\
(0.446)\end{array}$ & $\begin{array}{c}0.593 * * \\
(0.251)\end{array}$ \\
\hline lnDist & $\begin{array}{c}-0.280 * * * \\
(0.0389)\end{array}$ & $\begin{array}{c}-0.443 * * * \\
(0.0527)\end{array}$ & $\begin{array}{c}-0.270 * * * \\
(0.0380)\end{array}$ & & & \\
\hline lnREER & $\begin{array}{c}-0.808 * * * \\
(0.0790)\end{array}$ & $\begin{array}{c}-0.784 * * * \\
(0.0850)\end{array}$ & $\begin{array}{c}-0.932 * * * \\
(0.0820)\end{array}$ & $\begin{array}{c}-0.389 * * * \\
(0.0903)\end{array}$ & $\begin{array}{c}-0.236 * * \\
(0.0994)\end{array}$ & $\begin{array}{c}-0.448 * * * \\
(0.116)\end{array}$ \\
\hline lnSPCan & $\begin{array}{c}-0.473 * * * \\
(0.170)\end{array}$ & $\begin{array}{c}-0.462 * * \\
(0.188)\end{array}$ & $\begin{array}{c}-0.493 * * * \\
(0.138)\end{array}$ & $\begin{array}{c}-0.360 * * \\
(0.171)\end{array}$ & $\begin{array}{l}-0.265 \\
(0.187)\end{array}$ & $\begin{array}{c}-0.281^{*} \\
(0.164)\end{array}$ \\
\hline lnSPMex & $\begin{array}{c}-0.0130 \\
(0.298)\end{array}$ & $\begin{array}{l}-0.235 \\
(0.299)\end{array}$ & $\begin{array}{l}-0.183 \\
(0.200)\end{array}$ & $\begin{array}{l}-0.225 \\
(0.275)\end{array}$ & $\begin{array}{l}-0.405 \\
(0.272)\end{array}$ & $\begin{array}{c}-0.506 * * \\
(0.199)\end{array}$ \\
\hline $\ln T R_{t}^{i \rightarrow U S}$ & $\begin{array}{c}-0.257 * * \\
(0.125)\end{array}$ & $\begin{array}{c}-0.589 * * * \\
(0.158)\end{array}$ & $\begin{array}{c}-0.475 * * * \\
(0.154)\end{array}$ & $\begin{array}{c}0.811 * * * \\
(0.0271)\end{array}$ & $\begin{array}{c}0.726 * * * \\
(0.0299)\end{array}$ & $\begin{array}{c}0.884 * * * \\
(0.0254)\end{array}$ \\
\hline $\ln T R_{t}^{U S \rightarrow i}$ & $\begin{array}{c}1.052 * * * \\
(0.107)\end{array}$ & $\begin{array}{c}1.258 * * * \\
(0.130)\end{array}$ & $\begin{array}{l}1.210 * * * \\
(0.124)\end{array}$ & & & \\
\hline lnAge1 & $\begin{array}{c}-2.464 * * * \\
(0.353)\end{array}$ & $\begin{array}{c}-3.607 * * * \\
(0.494)\end{array}$ & $\begin{array}{c}-3.650 * * * \\
(0.507)\end{array}$ & $\begin{array}{c}-3.075 * * * \\
(0.390)\end{array}$ & $\begin{array}{c}-3.774 * * * \\
(0.486)\end{array}$ & $\begin{array}{c}-3.241 * * * \\
(0.504)\end{array}$ \\
\hline lnAge2 & $\begin{array}{c}-0.237 * * * \\
(0.0594)\end{array}$ & $\begin{array}{c}-0.217 * * * \\
(0.0696)\end{array}$ & $\begin{array}{c}-0.504 * * * \\
(0.0643)\end{array}$ & $\begin{array}{l}-0.113 * * \\
(0.0534)\end{array}$ & $\begin{array}{l}-0.0826 \\
(0.0543)\end{array}$ & $\begin{array}{c}-0.295 * * * \\
(0.0581)\end{array}$ \\
\hline Leng & $\begin{array}{l}0.849 * * * \\
(0.0331)\end{array}$ & $\begin{array}{c}0.691 * * * \\
(0.0433)\end{array}$ & $\begin{array}{c}0.684 * * * \\
(0.0434)\end{array}$ & $\begin{array}{c}0.811 * * * \\
(0.0386)\end{array}$ & $\begin{array}{c}0.769 * * * \\
(0.0452)\end{array}$ & $\begin{array}{c}0.778 * * * \\
(0.0454)\end{array}$ \\
\hline Lspan & $\begin{array}{c}0.661 * * * \\
(0.0518)\end{array}$ & $\begin{array}{c}0.521 * * * \\
(0.0586)\end{array}$ & $\begin{array}{c}0.695^{* * * *} \\
(0.0428)\end{array}$ & $\begin{array}{c}0.617 * * * \\
(0.0500)\end{array}$ & $\begin{array}{c}0.588 * * * \\
(0.0512)\end{array}$ & $\begin{array}{c}0.681 * * * \\
(0.0452)\end{array}$ \\
\hline Relig & $\begin{array}{c}0.245^{* *} \\
(0.108)\end{array}$ & $\begin{array}{c}0.180 \\
(0.119)\end{array}$ & $\begin{array}{c}0.638 * * * \\
(0.0859)\end{array}$ & $\begin{array}{c}0.0820 \\
(0.0873)\end{array}$ & $\begin{array}{c}0.0341 \\
(0.0966)\end{array}$ & $\begin{array}{c}0.492 * * * \\
(0.0818)\end{array}$ \\
\hline Casorigin & $\begin{array}{c}2.93 \mathrm{e}-05 \\
(0.000237)\end{array}$ & $\begin{array}{l}-0.000226 \\
(0.000293)\end{array}$ & $\begin{array}{c}0.000352 \\
(0.000227)\end{array}$ & $\begin{array}{c}-4.85 e-05 \\
(0.000228)\end{array}$ & $\begin{array}{l}-0.000244 \\
(0.000266)\end{array}$ & $\begin{array}{c}0.000346 \\
(0.000256)\end{array}$ \\
\hline Casus & $\begin{array}{c}1.09 \mathrm{e}-06 \\
(2.24 \mathrm{e}-06)\end{array}$ & $\begin{array}{c}2.16 \mathrm{e}-06 \\
(2.75 \mathrm{e}-06)\end{array}$ & $\begin{array}{l}-5.40 \mathrm{e}-07 \\
(3.09 \mathrm{e}-06)\end{array}$ & $\begin{array}{c}3.15 \mathrm{e}-06 \\
(2.79 \mathrm{e}-06)\end{array}$ & $\begin{array}{c}4.58 \mathrm{e}-06 \\
(2.91 \mathrm{e}-06)\end{array}$ & $\begin{array}{c}5.58 \mathrm{e}-07 \\
(4.20 \mathrm{e}-06)\end{array}$ \\
\hline VWP & $\begin{array}{l}-0.0739 \\
(0.0565)\end{array}$ & $\begin{array}{l}-0.0336 \\
(0.0817)\end{array}$ & $\begin{array}{c}-0.273 * * * \\
(0.0666)\end{array}$ & $\begin{array}{c}-0.406 * * * \\
(0.0738)\end{array}$ & $\begin{array}{c}-0.448 * * * \\
(0.0873)\end{array}$ & $\begin{array}{c}-0.423 * * * \\
(0.0842)\end{array}$ \\
\hline
\end{tabular}


Table 17 (continued). Augmented Gravity Model with Governance Indicators

\begin{tabular}{|c|c|c|c|c|c|c|}
\hline Variables & Model 5a & Model 5b & Model 5c & Model 5d & Model 5e & Model 5f \\
\hline MOU & $\begin{array}{c}0.350 * \\
(0.204)\end{array}$ & $\begin{array}{c}-0.00412 \\
(0.319)\end{array}$ & $\begin{array}{c}-0.204 \\
(0.190)\end{array}$ & $\begin{array}{c}0.738 * * * \\
(0.182)\end{array}$ & $\begin{array}{c}0.252 \\
(0.230)\end{array}$ & $\begin{array}{l}-0.220 \\
(0.206)\end{array}$ \\
\hline Ecorec & $\begin{array}{c}-0.152 * * * \\
(0.0456)\end{array}$ & $\begin{array}{c}-0.175 * * * \\
(0.0472)\end{array}$ & $\begin{array}{c}-0.173 * * * \\
(0.0403)\end{array}$ & $\begin{array}{l}-0.0690 \\
(0.0546)\end{array}$ & $\begin{array}{l}-0.0334 \\
(0.0582)\end{array}$ & $\begin{array}{l}-0.130 * * \\
(0.0510)\end{array}$ \\
\hline InCuldiv & $\begin{array}{l}-0.0169 * * \\
(0.00708)\end{array}$ & $\begin{array}{c}-0.0114 \\
(0.00896)\end{array}$ & $\begin{array}{l}-0.00229 \\
(0.00879)\end{array}$ & $\begin{array}{c}-0.0108 \\
(0.00721)\end{array}$ & $\begin{array}{l}-0.00943 \\
(0.00847)\end{array}$ & $\begin{array}{c}-0.0234 * * * \\
(0.00883)\end{array}$ \\
\hline lnVoiacct & $\begin{array}{c}-0.0533^{*} \\
(0.0308)\end{array}$ & $\begin{array}{c}-0.184 * * * \\
(0.0379)\end{array}$ & & $\begin{array}{c}-0.143 * * * \\
(0.0331)\end{array}$ & $\begin{array}{c}-0.248 * * * \\
(0.0374)\end{array}$ & \\
\hline lnPsav & $\begin{array}{c}0.0329 \\
(0.0320)\end{array}$ & $\begin{array}{c}0.0237 \\
(0.0353)\end{array}$ & $\begin{array}{c}0.0245 \\
(0.0190)\end{array}$ & $\begin{array}{c}0.0438 \\
(0.0322)\end{array}$ & $\begin{array}{c}0.0454 \\
(0.0350)\end{array}$ & $\begin{array}{c}0.0269 \\
(0.0215)\end{array}$ \\
\hline $\operatorname{lnffm}$ & $\begin{array}{c}0.0713 \\
(0.0545)\end{array}$ & $\begin{array}{c}0.293 * * * \\
(0.0914)\end{array}$ & & $\begin{array}{c}0.241 * * * \\
(0.0427)\end{array}$ & $\begin{array}{c}0.355^{* * *} * \\
(0.0580)\end{array}$ & \\
\hline lnGoveff & $\begin{array}{l}-0.398 \\
(0.557)\end{array}$ & $\begin{array}{c}-0.0372 \\
(0.609)\end{array}$ & & $\begin{array}{l}-0.647 \\
(0.551)\end{array}$ & $\begin{array}{l}-0.624 \\
(0.596)\end{array}$ & \\
\hline lnAuto & $\begin{array}{c}-0.935 * * * \\
(0.0877)\end{array}$ & & & $\begin{array}{c}-0.703 * * * \\
(0.0763)\end{array}$ & & \\
\hline lnefdex & & $\begin{array}{c}1.209 * * * \\
(0.181)\end{array}$ & $\begin{array}{c}0.301 \\
(0.206)\end{array}$ & & $\begin{array}{c}0.483 * * * \\
(0.144)\end{array}$ & $\begin{array}{l}-0.162 \\
(0.210)\end{array}$ \\
\hline lneddex & & & $\begin{array}{c}0.694 * * * \\
(0.187)\end{array}$ & & & $\begin{array}{l}-0.240 \\
(0.167)\end{array}$ \\
\hline lnDemo & & & $\begin{array}{c}0.599 * * * \\
(0.0919)\end{array}$ & & & $\begin{array}{c}0.651 * * * \\
(0.0967)\end{array}$ \\
\hline lnRolaw & & & $\begin{array}{c}0.137 \\
(0.515)\end{array}$ & & & $\begin{array}{l}-0.255 \\
(0.494)\end{array}$ \\
\hline $\operatorname{lnTC}$ & & & & $\begin{array}{c}-0.137 * * * \\
(0.0314)\end{array}$ & $\begin{array}{c}-0.210 * * * \\
(0.0354)\end{array}$ & $\begin{array}{l}-0.0606 * \\
(0.0311)\end{array}$ \\
\hline $\operatorname{lnRP}$ & & & & $\begin{array}{c}0.607 * * * \\
(0.0673)\end{array}$ & $\begin{array}{c}0.798 * * * \\
(0.0833)\end{array}$ & $\begin{array}{c}0.576 * * * \\
(0.0788)\end{array}$ \\
\hline Constant & $\begin{array}{c}30.95 * * \\
(12.90)\end{array}$ & $\begin{array}{c}23.18 \\
(14.35)\end{array}$ & $\begin{array}{c}29.57 * * * \\
(7.470)\end{array}$ & $\begin{array}{c}18.96 \\
(12.75)\end{array}$ & $\begin{array}{c}8.057 \\
(14.21)\end{array}$ & $\begin{array}{c}8.571 \\
(8.194)\end{array}$ \\
\hline $\begin{array}{l}\text { Observations } \\
\text { R-squared }\end{array}$ & $\begin{array}{c}454 \\
0.990\end{array}$ & $\begin{array}{c}454 \\
0.987\end{array}$ & $\begin{array}{c}459 \\
0.987\end{array}$ & $\begin{array}{c}454 \\
0.990\end{array}$ & $\begin{array}{c}454 \\
0.988\end{array}$ & $\begin{array}{c}459 \\
0.986\end{array}$ \\
\hline
\end{tabular}

Notes: Standard errors in brackets. $* * *, * *$ and $*$ denotes significance at $1 \%, 5 \%$, and $10 \%$ levels, respectively. 
Table 18. Augmented Gravity Model with Capital Investment and Linder Effects

\begin{tabular}{|c|c|c|c|c|c|c|}
\hline Variables & Model 6a & Model 6a & Model 6a & Model 6a & Model 6a & Model 6a \\
\hline lnRGDP-O & $\begin{array}{c}1.365 * * * \\
(0.190)\end{array}$ & $\begin{array}{c}0.297 * * * \\
(0.0225)\end{array}$ & $\begin{array}{c}1.671 * * * \\
(0.163)\end{array}$ & $\begin{array}{c}0.322 * * * \\
(0.0244)\end{array}$ & $\begin{array}{c}1.661 * * * \\
(0.164)\end{array}$ & $\begin{array}{c}0.328 * * * \\
(0.0250)\end{array}$ \\
\hline lnDist & $\begin{array}{c}-0.418 * * * \\
(0.0588)\end{array}$ & & $\begin{array}{c}-0.459 * * * \\
(0.0577)\end{array}$ & & $\begin{array}{c}-0.457 * * * \\
(0.0577)\end{array}$ & \\
\hline lnREER & $\begin{array}{c}-0.791 * * * \\
(0.0907)\end{array}$ & $\begin{array}{l}-0.228 * * \\
(0.0994)\end{array}$ & $\begin{array}{c}-0.843 * * * \\
(0.100)\end{array}$ & $\begin{array}{c}-0.378 * * * \\
(0.109)\end{array}$ & $\begin{array}{c}-0.829 * * * \\
(0.0999)\end{array}$ & $\begin{array}{c}-0.392 * * * \\
(0.109)\end{array}$ \\
\hline InSPCan & $\begin{array}{c}-0.752 * * * \\
(0.186)\end{array}$ & $\begin{array}{c}-0.349 * * \\
(0.165)\end{array}$ & $\begin{array}{c}-0.498 * * * \\
(0.165)\end{array}$ & $\begin{array}{c}-0.247 \\
(0.180)\end{array}$ & $\begin{array}{c}-0.501 * * * \\
(0.165)\end{array}$ & $\begin{array}{l}-0.212 \\
(0.183)\end{array}$ \\
\hline $\ln T R_{t}^{i \rightarrow U S}$ & $\begin{array}{l}-0.306 \\
(0.187)\end{array}$ & $\begin{array}{c}0.737 * * * \\
(0.0275)\end{array}$ & $\begin{array}{c}-0.586 * * * \\
(0.158)\end{array}$ & $\begin{array}{c}0.696 * * * \\
(0.0341)\end{array}$ & $\begin{array}{c}-0.577 * * * \\
(0.158)\end{array}$ & $\begin{array}{c}0.689 * * * \\
(0.0346)\end{array}$ \\
\hline $\ln T R_{t}^{U S \rightarrow i}$ & $\begin{array}{c}1.009 * * * \\
(0.150)\end{array}$ & & $\begin{array}{c}1.253 * * * \\
(0.129)\end{array}$ & & $\begin{array}{c}1.246^{* * * *} \\
(0.130)\end{array}$ & \\
\hline lnAge1 & $\begin{array}{c}-3.475 * * * \\
(0.494)\end{array}$ & $\begin{array}{c}-3.843 * * * \\
(0.490)\end{array}$ & $\begin{array}{c}-3.699 * * * \\
(0.501)\end{array}$ & $\begin{array}{c}-3.905 * * * \\
(0.460)\end{array}$ & $\begin{array}{c}-3.708 * * * \\
(0.503)\end{array}$ & $\begin{array}{c}-3.960 * * * \\
(0.459)\end{array}$ \\
\hline lnAge2 & $\begin{array}{c}-0.180 * * * \\
(0.0657)\end{array}$ & $\begin{array}{l}-0.0668 \\
(0.0545)\end{array}$ & $\begin{array}{c}-0.208 * * * \\
(0.0686)\end{array}$ & $\begin{array}{l}-0.0866 \\
(0.0530)\end{array}$ & $\begin{array}{c}-0.207 * * * \\
(0.0687)\end{array}$ & $\begin{array}{l}-0.0891 * \\
(0.0528)\end{array}$ \\
\hline Leng & $\begin{array}{c}0.694 * * * \\
(0.0457)\end{array}$ & $\begin{array}{c}0.771 * * * \\
(0.0453)\end{array}$ & $\begin{array}{c}0.679 * * * \\
(0.0457)\end{array}$ & $\begin{array}{c}0.742 * * * \\
(0.0470)\end{array}$ & $\begin{array}{c}0.685 * * * \\
(0.0459)\end{array}$ & $\begin{array}{c}0.742 * * * \\
(0.0470)\end{array}$ \\
\hline Lspan & $\begin{array}{c}0.493 * * * \\
(0.0589)\end{array}$ & $\begin{array}{c}0.585 * * * \\
(0.0514)\end{array}$ & $\begin{array}{c}0.498 * * * \\
(0.0638)\end{array}$ & $\begin{array}{c}0.540 * * * \\
(0.0566)\end{array}$ & $\begin{array}{c}0.501 * * * \\
(0.0641)\end{array}$ & $\begin{array}{c}0.530 * * * \\
(0.0579)\end{array}$ \\
\hline Relig & $\begin{array}{c}0.101 \\
(0.112)\end{array}$ & $\begin{array}{c}0.0330 \\
(0.0966)\end{array}$ & $\begin{array}{c}0.155 \\
(0.118)\end{array}$ & $\begin{array}{l}-0.0212 \\
(0.0954)\end{array}$ & $\begin{array}{c}0.151 \\
(0.118)\end{array}$ & $\begin{array}{l}-0.0350 \\
(0.0944)\end{array}$ \\
\hline Casorigin & $\begin{array}{c}-0.000246 \\
(0.000293)\end{array}$ & $\begin{array}{l}-0.000196 \\
(0.000257)\end{array}$ & $\begin{array}{l}-0.000216 \\
(0.000287)\end{array}$ & $\begin{array}{l}-0.000299 \\
(0.000272)\end{array}$ & $\begin{array}{l}-0.000210 \\
(0.000286)\end{array}$ & $\begin{array}{c}-0.000312 \\
(0.000275)\end{array}$ \\
\hline Casus & $\begin{array}{l}-4.14 \mathrm{e}-06^{*} \\
(2.30 \mathrm{e}-06)\end{array}$ & $\begin{array}{c}3.58 \mathrm{e}-06 \\
(2.59 \mathrm{e}-06)\end{array}$ & $\begin{array}{c}1.21 \mathrm{e}-06 \\
(2.58 \mathrm{e}-06)\end{array}$ & $\begin{array}{c}1.43 \mathrm{e}-06 \\
(2.74 \mathrm{e}-06)\end{array}$ & $\begin{array}{c}1.20 \mathrm{e}-06 \\
(2.58 \mathrm{e}-06)\end{array}$ & $\begin{array}{c}1.26 \mathrm{e}-06 \\
(2.72 \mathrm{e}-06)\end{array}$ \\
\hline VWP & $\begin{array}{l}-0.0119 \\
(0.0823)\end{array}$ & $\begin{array}{c}-0.462 * * * \\
(0.0881)\end{array}$ & $\begin{array}{l}-0.0268 \\
(0.0822)\end{array}$ & $\begin{array}{c}-0.427 * * * \\
(0.0803)\end{array}$ & $\begin{array}{l}-0.0227 \\
(0.0823)\end{array}$ & $\begin{array}{c}-0.414 * * * \\
(0.0794)\end{array}$ \\
\hline
\end{tabular}

Continued on next page. 
Table 18 (continued). Augmented Gravity Model with Capital Investment and Linder Effects

\begin{tabular}{|c|c|c|c|c|c|c|}
\hline Variables & Model 6a & Model 6a & Model 6a & Model 6a & Model 6a & Model 6a \\
\hline \multirow[t]{2}{*}{ MOU } & 0.101 & 0.249 & 0.000607 & 0.268 & 0.00474 & 0.267 \\
\hline & $(0.315)$ & $(0.234)$ & $(0.319)$ & $(0.221)$ & $(0.320)$ & $(0.221)$ \\
\hline \multirow[t]{2}{*}{ Ecorec } & $-0.118 *$ & 0.0132 & $-0.153 * * *$ & 0.110 & $-0.156 * * *$ & 0.125 \\
\hline & $(0.0640)$ & $(0.0598)$ & (0.0594) & $(0.0807)$ & $(0.0593)$ & $(0.0826)$ \\
\hline \multirow[t]{2}{*}{$\ln$ Voiacct } & $-0.187 * * *$ & $-0.245 * * *$ & $-0.178 * * *$ & $-0.244 * * *$ & $-0.179 * * *$ & $-0.241 * * *$ \\
\hline & (0.0399) & $(0.0361)$ & (0.0379) & $(0.0377)$ & $(0.0381)$ & $(0.0377)$ \\
\hline \multirow[t]{2}{*}{ lnCuldiv } & -0.00871 & -0.0124 & -0.0118 & -0.00650 & -0.0117 & -0.00572 \\
\hline & $(0.00895)$ & $(0.00872)$ & $(0.00907)$ & $(0.00808)$ & $(0.00907)$ & $(0.00803)$ \\
\hline \multirow[t]{2}{*}{$\operatorname{lnffm}$} & $0.345^{* * *}$ & $0.360 * * *$ & $0.300 * * *$ & $0.361 * * *$ & $0.301 * * *$ & $0.362 * * *$ \\
\hline & $(0.0901)$ & $(0.0589)$ & $(0.0914)$ & $(0.0549)$ & $(0.0916)$ & $(0.0546)$ \\
\hline \multirow[t]{2}{*}{ lnPsav } & $0.0616 * * *$ & $0.0771 * * *$ & $0.0430 * *$ & $0.0964 * * *$ & $0.0429 * *$ & $0.100 * * *$ \\
\hline & $(0.0229)$ & $(0.0221)$ & $(0.0210)$ & $(0.0248)$ & $(0.0210)$ & $(0.0250)$ \\
\hline \multirow[t]{2}{*}{ lnGoveff } & $1.088 * *$ & $-1.106^{* * *}$ & -0.261 & -0.399 & -0.278 & -0.371 \\
\hline & $(0.468)$ & $(0.360)$ & $(0.635)$ & $(0.701)$ & $(0.631)$ & $(0.704)$ \\
\hline \multirow[t]{2}{*}{ lnCapinvest } & $-0.419 * * *$ & -0.0590 & 0.00818 & -0.315 & 0.0145 & -0.332 \\
\hline & $(0.128)$ & $(0.0801)$ & $(0.181)$ & $(0.205)$ & $(0.179)$ & $(0.207)$ \\
\hline \multirow[t]{2}{*}{ lnefdex } & $1.096 * * *$ & $0.486 * * *$ & $1.277 * * *$ & $0.669 * * *$ & $1.261 * * *$ & $0.723^{* * *} *$ \\
\hline & $(0.184)$ & $(0.146)$ & $(0.202)$ & $(0.165)$ & $(0.205)$ & $(0.173)$ \\
\hline \multirow[t]{2}{*}{$\ln \mathrm{TC}$} & & $-0.195 * * *$ & & $-0.278 * * *$ & & $-0.294 * * *$ \\
\hline & & $(0.0337)$ & & $(0.0428)$ & & $(0.0439)$ \\
\hline \multirow[t]{2}{*}{$\ln R P$} & & $0.786^{* * *}$ & & $0.856^{* * *}$ & & $0.874 * * *$ \\
\hline & & $(0.0832)$ & & $(0.0857)$ & & $(0.0871)$ \\
\hline \multirow[t]{2}{*}{ LnRGDP-US } & & & $-1.668 * * *$ & 0.919 & $-1.630 * * *$ & $1.123^{*}$ \\
\hline & & & $(0.432)$ & $(0.567)$ & $(0.438)$ & $(0.585)$ \\
\hline \multirow[t]{2}{*}{ lnlinder1 } & & & 0.0226 & $0.0648 * * *$ & & \\
\hline & & & $(0.0180)$ & $(0.0241)$ & & \\
\hline \multirow[t]{2}{*}{ Inlinder2 } & & & & & 0.0176 & $0.0717 * * *$ \\
\hline & & & & & $(0.0168)$ & $(0.0248)$ \\
\hline \multirow[t]{2}{*}{ Constant } & -7.564 & $27.17 * * *$ & $32.54 * *$ & -0.549 & $32.00 * *$ & -5.903 \\
\hline & $(5.973)$ & (1.998) & $(13.46)$ & $(16.89)$ & $(13.58)$ & $(17.39)$ \\
\hline R-squared & 0.982 & 0.989 & 0.987 & 0.986 & 0.987 & 0.986 \\
\hline
\end{tabular}

Notes: Standard errors in brackets. $* * *, * *$ and $*$ denotes significance at $1 \%, 5 \%$, and $10 \%$ levels, respectively. 
Table 19. Estimation Results of System GMM Dynamic Model

\begin{tabular}{|c|c|c|c|c|c|c|}
\hline Variables & $\begin{array}{c}\text { Model 7a } \\
\text { One-step } \\
\operatorname{lag}(2 \text { 2) }\end{array}$ & $\begin{array}{c}\text { Model 7b } \\
\text { One-step } \\
\text { (robust) } \\
\text { lag(2 2) } \\
\end{array}$ & 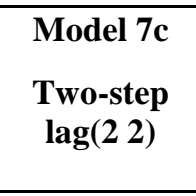 & $\begin{array}{l}\text { Model 7d } \\
\text { Two-step } \\
\text { (robust) } \\
\text { lag(2 2) } \\
\end{array}$ & 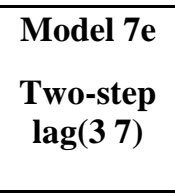 & $\begin{array}{c}\text { Model 7f } \\
\text { Two-step } \\
\text { (robust) } \\
\operatorname{lag}(37) \\
\end{array}$ \\
\hline L. $\operatorname{lnTA}$ & $\begin{array}{l}0.983 * * * \\
(0.00473)\end{array}$ & $\begin{array}{l}0.983^{* * * *} \\
(0.00699)\end{array}$ & $\begin{array}{l}0.984 * * * \\
(0.00309)\end{array}$ & $\begin{array}{l}0.986 * * * \\
(0.00876)\end{array}$ & $\begin{array}{l}0.989 * * * \\
(0.00387)\end{array}$ & $\begin{array}{l}0.989 * * * \\
(0.00876)\end{array}$ \\
\hline L.InRGDP-O & $\begin{array}{c}-2.533 * * * \\
(0.187)\end{array}$ & $\begin{array}{c}-2.533 * * * \\
(0.461)\end{array}$ & $\begin{array}{c}-2.387 * * * \\
(0.210)\end{array}$ & $\begin{array}{c}-2.138 * * * \\
(0.606)\end{array}$ & $\begin{array}{c}-2.044 * * * \\
(0.288)\end{array}$ & $\begin{array}{c}-2.044 * * * \\
(0.590)\end{array}$ \\
\hline L.InRGDP-US & $\begin{array}{l}0.00917 \\
(0.298)\end{array}$ & $\begin{array}{l}0.00917 \\
(0.594)\end{array}$ & $\begin{array}{l}-0.150 \\
(0.285)\end{array}$ & $\begin{array}{l}-0.846 \\
(0.715)\end{array}$ & $\begin{array}{c}-0.930^{* * *} \\
(0.329)\end{array}$ & $\begin{array}{l}-0.930 \\
(0.712)\end{array}$ \\
\hline lnRGDP-O & $\begin{array}{c}2.548 * * * \\
(0.187)\end{array}$ & $\begin{array}{c}2.548 * * * \\
(0.462)\end{array}$ & $\begin{array}{c}2.401 * * * \\
(0.210)\end{array}$ & $\begin{array}{c}2.151 * * * \\
(0.607)\end{array}$ & $\begin{array}{c}2.055^{* * *} \\
(0.289)\end{array}$ & $\begin{array}{c}2.055^{* * * *} \\
(0.591)\end{array}$ \\
\hline lnRGDP-US & $\begin{array}{c}-0.00914 \\
(0.298)\end{array}$ & $\begin{array}{c}-0.00914 \\
(0.595)\end{array}$ & $\begin{array}{c}0.149 \\
(0.284)\end{array}$ & $\begin{array}{c}0.927 \\
(0.710)\end{array}$ & $\begin{array}{c}1.056^{* * * *} \\
(0.368)\end{array}$ & $\begin{array}{c}1.056 \\
(0.785)\end{array}$ \\
\hline $\operatorname{lnDist}$ & $\begin{array}{c}-0.0190^{* * *} \\
(0.00733)\end{array}$ & $\begin{array}{l}-0.0190 \\
(0.0144)\end{array}$ & $\begin{array}{l}-0.0166^{* *} \\
(0.00682)\end{array}$ & $\begin{array}{l}-0.0141 \\
(0.0178)\end{array}$ & $\begin{array}{l}-0.0114^{*} \\
(0.00635)\end{array}$ & $\begin{array}{l}-0.0114 \\
(0.0158)\end{array}$ \\
\hline lnREER & $\begin{array}{c}-0.399 * * * \\
(0.0327)\end{array}$ & $\begin{array}{c}-0.399 * * * \\
(0.0573)\end{array}$ & $\begin{array}{c}-0.390 \text { *** } \\
(0.0269)\end{array}$ & $\begin{array}{c}-0.317 * * * \\
(0.0689)\end{array}$ & $\begin{array}{c}-0.275^{* * *} \\
(0.0416)\end{array}$ & $\begin{array}{c}-0.275^{* * *} \\
(0.0887)\end{array}$ \\
\hline Ecorec & $\begin{array}{l}0.0392 * \\
(0.0203)\end{array}$ & $\begin{array}{c}0.0392 \\
(0.0268)\end{array}$ & $\begin{array}{c}0.0383 * * * \\
(0.00830)\end{array}$ & $\begin{array}{c}0.0412 \\
(0.0305)\end{array}$ & $\begin{array}{c}0.0428^{* * * *} \\
(0.00747)\end{array}$ & $\begin{array}{c}0.0428 \\
(0.0282)\end{array}$ \\
\hline Constant & & & & $\begin{array}{l}-2.498 \\
(4.025)\end{array}$ & $\begin{array}{l}-3.921 \\
(3.077)\end{array}$ & $\begin{array}{l}-3.921 \\
(5.387)\end{array}$ \\
\hline $\begin{array}{l}\text { Auto1 } \\
\text { Auto } 2 \\
\text { Sargan test } \\
\text { Hansen test } \\
\text { Wald }\end{array}$ & $\begin{array}{c}0.000 \\
0.082 \\
240.17(104) \\
\\
1.1 \mathrm{e} 07(000)\end{array}$ & $\begin{array}{c}0.000 \\
0.099 \\
25.93(104) \\
3.7 \mathrm{e} 05(000)\end{array}$ & $\begin{array}{c}0.001 \\
0.083 \\
25.93(104) \\
6.4 \mathrm{e} 06(000)\end{array}$ & $\begin{array}{c}0.001 \\
0.131 \\
25(103)\end{array}$ & $\begin{array}{c}0.001 \\
0.098 \\
25.06(222)\end{array}$ & $\begin{array}{c}0.001 \\
0.125 \\
25.06(222)\end{array}$ \\
\hline No. observations & 428 & 428 & 428 & 428 & 428 & 428 \\
\hline Number of countryid & 27 & 27 & 27 & 27 & 27 & 27 \\
\hline $\begin{array}{l}\text { Long-run parameters } \\
\text { lnRGDP-O } \\
\text { lnRGDP-US } \\
\text { lnDist } \\
\text { lnREER }\end{array}$ & $\begin{array}{l}-1.12 \\
-23.47\end{array}$ & 149.88 & $\begin{array}{c}-1.04 \\
-24.38\end{array}$ & 153.64 & $\begin{array}{c}186.82 \\
96.0 \\
-1.04 \\
-25.0\end{array}$ & $\begin{array}{l}186.82 \\
-1.04 \\
-25.0\end{array}$ \\
\hline
\end{tabular}

Notes: Standard errors in brackets. ***, ** and $*$ denotes significance at $1 \%, 5 \%$, and $10 \%$ levels, respectively. 
The short-run elasticity of real GDP in both source and destination countries as shown in model 7e are positive and significantly affect tourism demand in the United States. The estimated values of the short-run and long-run elasticities of the real GDP of the originating and destination countries exceeds one (1), suggesting that tourism in the United States is a luxury good for the source countries. The estimated coefficient of the real GDP in the source countries in table 18 is very similar to that of model $3 \mathrm{a}$ in table 14 , and the highest of the estimates, indicating that tourism flows to the U.S is heavily dependent on the income of the originating countries. The distance and the real exchange variable are negative and significant determinants of tourist arrival in the U.S in the short and long-run, which is in sync with economic theory.

\section{Discussion, Conclusions and Policy Implications}

It is imperative to understand the push and pull factors that influence the flow of international tourist to the United States, given the critical role that tourism plays in the U.S. economy, and the growing competition in the global tourism industry. The study unpacks this push and pulls factors from the originating, destination, and contiguous countries to the United States. Using annual data on 27 countries from 1996 to 2014, the study employed Poisson Pseudo Maximum Likelihood and the systems Generalized Methods of Moments within the gravity framework to examine the determinants of international tourist flow to the United States. The basic static gravity model was augmented with economic, demographic, and cultural factors, governance indicators and Linder effects variables to examine their impact on the decisions of international tourist to travel to the United States.

The results from the dynamic model indicate that the variables in the traditional basic gravity model are significant determinants of inbound tourism in the United States. The incomes of destination and origin countries proxied by their real GDP's, distance, and the real exchange 
rates significantly explain international tourist flow to the United States in both the short and long run. A percentage increase in the income of the source countries results in between $2.05 \%$ and $2.54 \%$ increase in tourist arrival in the short run and between $149.88 \%$ and $186.82 \%$ in the long run. This suggest that the economic conditions of the source countries are important in tourist decision to travel in both short and long runs which is consistent with the results of earlier scholars on tourism demand (Ekanayake, Halkides, and Ledgerwood, 2012; Vietze. 2012; Deese, 2013; and Yadzi and Khanalizadeh, 2017) in the U.S. The estimated short-run coefficient of the income of the source countries is large suggesting that tourism in the U.S. is highly dependent on the economies of the source countries. Tourism demand in the U.S. is therefore income elastic given that short-run elasticity is positive and more than unity, hence considered a luxury service by foreigners. This finding reinforces earlier empirical studies which found tourism in the U.S. to be a luxury good of (Ekanayake, Halkides, and Ledgerwood, 2012), but contradicts other findings that tourism in the U.S. is a non-luxury good (Vietze, 2012; Deese, 2013; and Yadzi and Khanalizadeh, 2017).

The income elasticities of the destination country (U.S.) is large (above unity) but less than that from the origin country. A $1 \%$ increase in the U.S. economy leads to $1.056 \%$ and $96 \%$ rise in tourist arrival in the short and long runs respectively. International tourist decision to travel is therefore highly dependent on the economy of the destination country, though less than the economies of origin countries. International tourist tends to patronize tourism goods and services in developed economies because they tend to have better tourism infrastructure such as roads, transportation systems, accommodation, and services. This supports earlier findings of the economy-driven tourism hypothesis in the United States by Tang and Jang (2009); Alawin and Abu-lila (2016) in Jordan; Wang and Xi (2016), Lorde, Li, and Airey (2015) in the Caribbean; 
Keum (2008) in Korea; and Roy and Rayhan (2012) in Bangladesh. However, it contradicts earlier work by Vietze (2012) which observed that the U.S. economy negatively influence tourist flow to the United States. This suggests that the economic performance in the destination country enhance its competitiveness thereby increasing tourism demand.

The hypothesis that habit persistence and/or word-of-mouth positively influence inbound tourism to the United States is supported by the coefficients of the lagged dependent variables in all the specifications in the dynamic model. The results reinforce the findings of other tourism studies in other countries (Li, and Airey, 2015; Peng, Song, Crouch, and Witt, 2014; Habibi, Rahim, Ramchandran, and Chin, 2009; and Garin-Munoz, 2006 and 2007). Comparable to Malaysia (Garin-Munoz, 2006), over 90 percent of tourist arrivals in the United States are repeat visitors, and/or tourists influenced by the word-of-mouth (WoM) narration of experience by the previous tourist to the U.S. The estimated coefficient suggests that a change in any of the determinants will result in inbound tourism adjust to a new equilibrium at a rate of $98 \%$ in the year after. Furthermore, repeat visitations to the United States are very high given the size and significance of the estimated coefficient.

Lagged incomes in origin and destination countries are significant but negative. This indicates that previous standard of living in the source countries, and in the United States negatively affect tourist flow to the U.S. It suggests that increasing international tourist arrivals in the U.S. are largely due to the current and not previous standards of living (or economic performance) of the source and destination countries. The distance between the origin and destination countries, and the real exchange rate are negative and significant. An increase in distance by $1 \%$ will lead to $0.01 \%$ and $1.04 \%$ drop in the number of tourists arriving in the U.S. in the short and long run respectively. The estimated coefficient of the distance variable is significant, 
implying that distance is an important consideration in the decision making of international tourist. Longer distance will mean longer travel time and higher travel cost which may dis-incentivize international tourist to travel. Increasing distance therefore decrease tourism demand in the U.S., reinforcing earlier studies in the U.S. (Vietze, 2012; Deese, 2013).

Similarly, the real effective exchange rate negatively influences tourist decision to travel. An increase in the exchange rate by $1 \%$ will result in a decrease of about $0.39 \%$ in the short run, and $24.38 \%$ in the long run. Exchange rate plays an important role in driving tourism demand, given that currencies of source countries will have to be exchanged to U.S. dollars to undertake the trip. In the long run, source countries are very sensitive to the strength of the domestic currencies against the U.S. dollar as indicated by the coefficient exchange rate elasticity.

The study also reveals that most of the economic factors are significant determinants of international tourist flow to the United States. The relative cost of living and the travel cost in the augmented models were significant and negative. Outbound tourism from originating countries falls by $0.30 \%$ for a $1 \%$ increase in the cost of living in the United States. International tourists are sensitive to prices of goods and services in the destination country. Therefore, providers of tourism goods and services in the United States should be strategic in their pricing policy since that could serve as a disincentive to international tourists. Similarly, the decision by tourist to travel is informed by travel cost. The results indicate that a $1 \%$ increase in travel cost will reduce outbound tourist from the source countries by 0.40 . While lower prices of tourism goods and services, and lower travel cost enhance tourism demand, the latter has a higher impact. Earlier studies by Elkanayake et al. (2012), Vietze (2012), and Deese (2013) observed similar findings.

The substitute price or relative price of competing countries represent a ratio of prices in the United States and the contiguous countries (Mexico and Canada), which indicate whether 
prices of goods and services in the U.S. is lower/expensive relative to Canada and Mexico. The substitute prices of tourism goods and services in Mexico and Canada, which share boundaries with the United States are negative and significant. They also share some geographical and cultural similarities and may provide similar goods and services. A rational consumer with full information will show a preference for a destination that offers similar services with at a lower cost. The results show that tourism demand in the United States decreases by $0.89 \%$ and $0.88 \%$ for a $1 \%$ increase in tourism price in the U.S relative to Canada and Mexico respectively. This suggests that international tourists are very sensitive to substitute prices in Canada and Mexico, therefore decreasing prices in these contiguous countries portend increasing tourism demand in the United States.

Other economic factors such as trade openness between source countries and the United States and capital investment significantly explain tourist flow to the United States. We examine trade relationship between origin and destination countries as a share of the sum of imports and exports to GDP of origin and destination countries contrary to most tourism literature that considered only the latter. Outbound tourism from source countries to the U.S increases between $0.37 \%$ and $0.92 \%$ for a $1 \%$ increase in trade openness concerning origin countries, and between $0.51 \%$ and $0.82 \%$ for trade openness concerning the United States. The estimated coefficients suggest that the source and destination countries are economically linked via trade and therefore facilitate business travels to the United States. Consequent to this may be follow up visits to friends and families for leisure, and in some cases for academic and health reasons. Also, consumption of trade goods from the United States helps foreigners to learn more about the U.S. as a potential place to visit. Trade openness increases tourism demand by generating and promoting different tourism activities such as leisure tourism, visits to family and friends, academic tourism, and health 
tourism besides business tourism. Furthermore, it is useful in the word-of-mouth advertisement that further enhance tourism flow to the United States. The results also show that trade openness in terms of trade flow from origin countries to the U.S. has a slightly higher effect on U.S. tourism demand than trade openness with respect to flow from the U.S to origin countries.

Investment in tourism infrastructure significantly and positively influences tourism demand, albeit small in developed economies like the United States. Tourism demand increases between $0.001 \%$ and $0.007 \%$ for a $1 \%$ increase in capital investment. The estimated coefficient of capital investment is very small probably because the investment is spread throughout the different sectors of the U.S. economy, and/or that its impact is captured by the country-specific effects. This value may appreciate if data of capital investment specifically on tourism infrastructure is used. The effect of capital investment in tourism infrastructure development on tourism demand is unique to this paper in the tourism demand literature in the United States. Against the backdrop of tourism flow between countries of economic similarity akin to trade flows in the international trade literature, the study provides evidence in support of the Linder hypothesis in the United States. The estimated coefficients of linder 1 and linder2 variables are negative and significant determinant of tourism demand. Tourist flow, therefore, increases as the per capita of the source and destination countries converge. From linder 2 variable, the tourism demand elasticity is between $0.50 \%$ and $0.91 \%$ for a $1 \%$ change in income similarity. This suggests that tourists are prone to travel to the United States as the per capita income of origin countries and the U.S. converge. While the Linder hypothesis is an emerging area in tourism studies, this is its first application in the U.S. tourism literature. The support for the Linder hypothesis in this study may also be attributed to the source countries. Apart from India, all origin countries are high income and higher upper-middle-income countries whose aggregate economy converges towards the U.S. economy. Also, tourists are 
inclined to travel to developed economies like the United States where tourism infrastructure such as roads, transportation, telephone, internet, and hotel accommodation are well developed.

The study explored demographic influence on tourism demand in details not observed in the U.S. tourism literature as far as we know. Contrary to expectations, population significantly influences U.S. tourism demand inversely. Tourist flows to the United States are reduced by $0.31 \%$ for a one percent increase in population, which is similar to the results of earlier studies by Vietze (2012) and Deluna and Joen (2014). Using the area of the country as a proxy for size, Vietze (2012) observes that tourists' inclination to travel outside the destination country decreases with size. Disaggregating population into percentages of ages between 15-64 years and beyond 64 years provided similar results. A percentage increase in the population age between 15-64 years and above 64 years leads to inbound tourism in the U.S. decreasing by $3.5 \%$ and $0.44 \%$ respectively with the former having a greater impact than the latter.

Further, the number of international tourists visit the United States decreases by $23.61 \%$ with a percentage increase in the proportion of the male population in the origin countries. This suggests that the male populations in the tourist generating countries are less inclined to travel outside even as their population increases, a position unexplained in this paper. As expected, however, urbanization significantly impact tourism demand - the number of tourist arrival in the U.S. increases by $1.28 \%$ for a $1 \%$ increase in the rate of urbanization of origin countries. Urbanization is synonymous to industrialization and civilization (Song and Witt, 2009) with the propensity for people to explore experiences outside their home countries. Furthermore, urban centers are usually associated with people who are literates and can fund international tourism trips. These may account for the drive for outbound tourism from the origin countries including the stress of city living. Given that about an average of $75 \%$ of the population reside in urban 
centers, increasing urban centers in the source countries will drive tourism demand in the United States. The implication is that it is the population in urban centers that drive tourism demand.

Cultural similarities are a significant determinant of tourism demand. The similarities of the predominant language spoken, and the religious faith of the origin and destination countries facilitates tourism demand. On the average tourist arrival in the United States increases from English and Spanish speaking countries, suggesting that language plays a significant role in the decisions of international tourists. Tourism demand for the U.S., however, decreases from origin countries that speak other languages. Similarly, the study showed that tourist arrival in the United States is positively and significantly affected by origin countries with predominantly Christian faith. This implies that tourists are more inclined to travel to countries that share a common way of life regarding language and religious faith.

An important finding of this study is the role of institutions, governance structures, civil liberties, and human development indexes on tourism demand, which has been examined earlier by Vietze (2012). While Vietze (2012) considered institutions in origin countries, this study examined how institutions in both origin and destination countries influence tourism demand in the United States. It is evident that the governance and institutional structure in the origin countries significantly influence tourism demand. Countries in which citizens have unrestricted freedom to travel in and out of the country are more likely to visit the United States. Higher economic freedoms and education in origin countries also incentivize the demand for U.S. tourism goods and services, which further support the findings on the effect of urbanization. We also observed that institutionalized democracies that provide choice and guarantees civil liberties and freedom in origin countries enhance tourism demand, while autocratic regimes negatively affect tourism demand. 
Voice accountability and cultural diversity in the source countries inversely influence inbound tourism in the United States. While we are unable to explain the negative effect of voice accountability, we surmise that increasing cultural distance or dissimilarities among groups dilute the proportion of English or Spanish speaking population hence the negative sign of cultural diversity. The study further shows that governance indicators in the destination country influence tourism demand. Government effectiveness, and political stability and absence of violence in the United States positively influence foreign visit to the United States. Surprisingly, the rule of law in the United States is not a significant determinant of tourism demand.

The results provide support for the significant impact of certain specific government policies on the decisions of foreign visitors to travel. The U.S. visa waiver program is a positive and significant determinant of inbound tourism to the United States. The program eliminates the bottlenecks of traveling to the United States and incentivize the flow of tourist from beneficiary countries of the program. Similarly, the memorandum of understanding (MOU) between China and the United States remove regulatory restrains from tourism marketing and leisure travel from China to the United States. Following the MOU, China moved from the $17^{\text {th }}$ largest tourism market for the U.S. in 2007 to the largest market by 2016. The implication is that specific and targeted policy interventions by host countries portend greater dividend for tourism demand in the host countries.

Incidental events may also influence tourist decisions to travel. The economic recession of 2007 in the United States negatively and significantly affect the number of tourists visiting the United States. Tourism demand is also influenced by terrorist attacks. Unique to this paper, we used the number of casualties (deaths and injuries) from a terrorist attack in the origin and destination countries instead of the dummy variable for a terrorist attack in the literature. While 
casualties from a terrorist attack in the U.S. is not significant, casualties in the origin countries are significant and negatively affect tourism demand. Tourists, therefore, are less inclined to travel out of their home country when there is an increasing number of casualties from a terrorist attack in the home country.

These findings have implications for policymakers. It is recommended that tourism infrastructure development be considered given its potential to attract international tourist to the United States. The improved goods and services arising from capital investment in the tourism industry will not only attract repeat visits, but also tourist influenced by word-of-mouth narrative of the pleasant experience. It is further recommended that strategic pricing policy on tourism goods and services be given the needed attention by industry players to make the industry more competitive in the global market, since the industry is sensitive to price in source countries and competing for contiguous countries. Given that trade, the relationship provides not only direct but spillover benefits for tourism demand, efforts at creating and improving trade relationships with source countries without or with weak trade relationship. The tourism industry is dependent on the economies of the source countries and so policymakers should design strategies that target fastgrowing economies. Also, political stability and absence of violence is an important determinant of inbound tourism. Efforts at eliminating or minimizing instability and violent incidents will help in attracting foreign visitors to the United States. 


\section{REFERENCES}

Arellano, M., and Bond, S. (1991). 'Some tests of specification for panel data: Monte Carlo evidence and an application to employment equations.' Review of Economic Studies, 58: 277-97.

Alawin, M., and Abu-lila, Z. (2016). 'Uncertainty and gravity model for international tourism demand in Jordan: evidence from panel-GARCH model.' Applied Econometric and International Development, 16(1): 131-142.

Baltagi, B.H. (1995). Econometric Analysis of Panel Data. Chichester; Wiley.

Bashagi, A., and Muchapondwa, E. (2009). 'What actions could boost international tourism demand for Tanzania.' Working Paper Number 152, 1-14, University of Cape Town.

Christie, I.T. (2002). 'Tourism, growth, and poverty: framework conditions for tourism in developing countries'. Tourism Review, 57(12): 35-41.

Crouch, G., and Shaw, R. (1992). 'International tourism demand: a meta-analytical integration of research findings,' in Peter Johnson and Barry Thomas, eds, Choice and Demand in Tourism, Mansell, London, 175-207.

Deese, W. (2013). 'Determinants of inbound travel to the United States.' Office of Economics Working Paper, U.S. International Trade Commission., No. 2013-02A, 1-36.

Durbarry, R. (2000), 'Tourism expenditures in the UK: analysis of competitiveness using a gravity-based model,' Christel DeHaan Tourism and Research Institute, Nottingham University and Business School.

Deluna, R.J., and Joen, N. (2014). 'Determinants of international tourism demand for the Philippines: An Augmented Gravity Model approach.' School of Applied Economics, University of Southeastern Philippines, Munich Personal RePEc Archive. <http://mpra.ub.uni-muenchen.de/55294/MPRA Paper No. 55294. 1-19.

Eadington, W.L., and Redman, M. (1991). 'Economics and tourism.' Annals of Tourism Research, 18: 41-56.

Ekanayake, E.M., Halkides, M., and Ledgerwood, J.R. (2012). 'Inbound international tourism to the united states: A panel data analysis,' International Journal of Management and Marketing Research, 5(3): 15-27.

Garin-Munoz, T., and Amaral, T.P. (2000). 'An econometric model for international tourism flows to Spain.' Applied Economics Letters, 7:525-529.

Garin-Munoz, T. (2006). 'Inbound international tourism to Canary Islands: a dynamic panel data model.' Tourism Management, 27:281-291. 
Garin-Munoz, T., and Montero-Martin, L.F. (2007). 'Tourism in the Balearic Islands: a dynamic model for international demand using panel data.' Tourism Management, 28:1224-1235.

Greene, W.H. (2008). 'Econometric analysis, $6^{\text {th }}$ edition. Pearson Prentice Hall, Upper Saddle River.

Habibi, F., Rahim, K.A., Ramchandran, S., and Chin, L. (2009). 'Dynamic model for international tourism demand for Malaysia: Panel data evidence.' International Research Journal of Finance and Economics, 33:207-217.

International Trade Administration, National Travel and Tourism Office, (2015). Fast facts: United States Travel and Tourism industry. 〈http://tinet.ita.doc.gov/outreachpages/download data table/Fast Facts 2015.pdf>.

International Trade Administration, National Travel and Tourism Office, (2015). Travel Promotion Act - Detailed summary of key points.

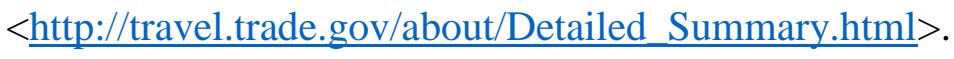

International Trade Administration, National Travel and Tourism Office, (2015). National Travel and Tourism Strategy: Task Force on Travel and Competitiveness, 2012. <http://tinet.ita.doc.gov/pdf/national-travel-and-tourism-strategy.pdf>.

International Trade Administration, National Travel and Tourism Office, (2016). U.S Commerce Department releases six-year forecast for international travel to the United States - 20162021. 〈http://travel.trade.gov/view/f-2000-99-001/forecast/Forecast Summary.pdf - U.S〉>

Isard, W. (1954). 'Location theory and international and interregional trade theory.' The Quarterly Journal of Economics, 68(1): 97-114.

Keum, K. (2010). 'Tourism flows and trade theory: a panel data analysis with the gravity model.' Annual Regional Science, 44:541-557. DOI: 10.1007/s00168-008-0275-2.

Lederbogen, F., Kirsch, P., Haddad, L., Streit., F., Tost, H., Schuch, P., Wust, S., Pruessner, J.C., Rietschel, M., Deuschle, M., and Meyer-Lindenberg, A. (2011). 'City living and urban upbringing affect neural social stress processing in humans.' Nature, 474(7352:498-501.

Ledesma-Rodriguez, F. J., Navarro-Ibanez, M. and Perez-Rodriguez, J. V. (1999). 'Panel data and tourism demand. The case of Tenerife'. http://www.fedea.es/hoias/publicaciones.html\#DocumentosdeTrabaio Date accessed: 03 May 2006.

Linder, S. (1961) An essay on trade and transformation. Almqvist \& Wiksells, Stockholm Linnemann, H. (1966). An econometric study of international trade flows. North-Holland Publishing Co., Amsterdam. 
Lorde, T., Li, G., and Airey, D. (2015). 'Modelling Caribbean tourism demand: an augmented gravity model.' Journal of Travel Research, 1-11. DOI: 10.1177/0047287515592852.

Lucci, G., and Flucker, Y. (2003). 'An econometric estimation of the demand for tourism: the case of Switzerland.' Pacific Economic Review, 8(3): 289-303.

Lyomasa, M.A. (1983). 'Analysis of nonimmigrant visa waiver legislation in the USA.' Tourism Management, 4(2): 102-106.

Malgarinin, M., and Margani, P. (2007). 'Psychology, consumer sentiment and household expenditures.' Applied Economics, 39(13): 1719-1729.

Marrocu, E., Paci, R., and Zara, A. (2015). 'Micro-economic determinants of tourist expenditure: a quantile regression approach'. Tourism Management, 50: 13-30.

Muchapondwa, E., and Pimhidzai, O. (2008). 'Modelling international tourism demand for Zimbabwe.' ERSA Working Paper No. 107, November.

Naude, W.A., and Saayman, A. (2005). 'The determinants of tourist's arrivals in Africa: a panel data regression analysis.' Tourism Economics, 11(3): 365-391.

Nordstrom, J. (2005). 'Dynamic and stochastic structures in tourism demand modeling.' Empirical Economics, 30:379-392.

Peng, B., Song, H., Crouch, G.I., Witt. S.F. (2015). 'Meta-analysis of international tourism demand elasticities.' Journal of Travel Research, 54(5): 611-633. DOI: $10.1177 / 0047287514528283$.

Pllaha, A. (2012). 'Free trade agreements and trade integration among south Eastern European countries: gravity model estimation.' Working Paper, The Bank of Albania, 1-32.

Prehn, S., Brummer, B., and Glauben, T. (2015). 'Gravity model estimation: fixed effects vs. random intercept Poisson pseudo maximum likelihood.' ResearchGate. DOI: 10.13140/2.1.1601.1044.

Proenca, S.A., and Soukiazis, E. (2005). 'Demand for tourism in Portugal: a panel data approach.' hn ://w4.fe.uc.pt $\sim$ ceue/workin \% 20 a ers/Sar lias2D9a.t e df. accessed: 05 May 2006.

Roy, M., and Rayhan, I. (2012). 'Import flows of Bangladesh: gravity model approach under panel data methodology.' Dhaka University Journal of Science, 60(2): 153-157.

Silva, J.M.C.S., and Tenreyro, S. (2006). 'The log of gravity.' The Review of Economics and Statistics, 88(4): 641-658. 
Serlenga, L., and Shin, Y. (2006). 'Monte Carlo studies on finite sample performance of the CCEPHT estimator in panels with heterogenous unobserved common factors.' Working Paper, University of Leeds.

Sigala, M., Lockwood, A., and Jones, P. (2001),' Strategic implementation and IT: Gaining competitive advantage from the hotel reservations process.' International Journal of Contemporary Hospitality Management, 13: 364-371.

Smeral, E. (2003). Die Zukunft des internationalen Tourismus, Vienna: Austrian Institute of Economic Research (WIFO).

Smith, J. (2006). 'The determination of the international demand for tourism to South Africa.' Masters dissertation, School of Economic, Risk Management and International Trade, North-West University, 1-118.

Song, H., Witt, SF., and Li, G. (2009). The Advanced Econometrics of Tourism Demand. Routledge Tailor and Francis, New York: United States.

Song, H., Li, G., Witt, S.F., and Fei, B. (2010). 'Tourism Demand Modeling and Forecasting: How Should Demand Be Measured?'. Tourism Economics, 16: 63-81. DOI: 10.5367/000000010790872213.

Stock, J.H., and Watson, M.W. (2003). Introduction to Econometrics. Boston: Addison Wesley Longman.

Tang, C.H. and Jang, S.C. (2009). 'The tourism-economy causality in the United States: A subindustry level examination.’ Tourism Management, 30: 553-558.

U.S Travel Association (2015). Fact sheet: International inbound travel to the U.S. <https://www.ustravel.org/system/files/Media\%20Root/Document/Research_FactSheet_International-Inbound.pdf>.

Travel Promotion, Enhancement, and Modernization Act of 2014. <https://www.congress.gov/bill/113th-congress/house-bill/4450〉.

Uysal, M. and Crompton, J.L. (1985). 'Deriving a relative price index for inclusion in international tourism demand estimation models.' Journal of Travel Research, 24(1): 3234.

Vail, D., and Heldt, T. (2000). 'Institutional factors influencing the size and structure of tourism: comparing Dalarna (Sweden) and Maine (USA).' Current issues in tourism, 3(4): 283324.

Vencovska, J. (2014). 'The determinants of international tourism demand.' Bachelor thesis, Faculty of Social Sciences, Charles University in Prague. 
Vietze, C. (2008). 'Cultural effects on inbound tourism into the U.S.A: a gravity approach.' Jena Economic Research Papers, Schiller University and Max Planck Institute of Economics, Jena.

Vietze, C. (2012). 'Cultural effects on inbound tourism into the U.S.A: a gravity approach.' Tourism Economics, 18(1):121-138.

Walsh, M. (1996). 'Demand analysis in Irish tourism.' Journal of the statistical inquiry Society of Ireland, 27 (4): 1-30.

Wang, H., and Xi, J. (2016). 'The determinant of inbound tourism in China.' International Journal of Business and Management, 11(2): 205-2011.

Witt, S. F., and Martin, C. A. (1987). 'Econometric models for forecasting international tourism demand.' Journal of Travel Research, 25(3): 23-30.

Yazdi, S.K., and Khanalizadeh, B. (2017). 'Tourism demand: a panel data approach.' Current Issues in Tourism, 20(8):787-800.

Zhou, M. (2011). 'Intensification of geo-cultural homophily in global trade: Evidence from the gravity model.' Social Science Research, 40(1): 193-209. 


\section{APPENDIX FOR CHAPTER 4}

Table A1. Estimated Results of Pooled, Fixed and Random Effects Models

\begin{tabular}{|c|c|c|c|}
\hline VARIABLES & OLS-robust & Fixed effect-robust & Random effect-robust \\
\hline lnrgdpo & $\begin{array}{c}0.221 * * * \\
(0.0318)\end{array}$ & $\begin{array}{c}1.576^{* * * *} \\
(0.199)\end{array}$ & $\begin{array}{c}0.829 * * \\
(0.363)\end{array}$ \\
\hline lnrgdpd & $\begin{array}{c}0.848 * * \\
(0.399)\end{array}$ & $\begin{array}{c}-1.041 * * * \\
(0.339)\end{array}$ & $\begin{array}{c}0.00103 \\
(0.431)\end{array}$ \\
\hline lndist & $\begin{array}{c}-0.521 * * * \\
(0.100)\end{array}$ & & $\begin{array}{c}-0.734 \\
(0.742)\end{array}$ \\
\hline ecorec & $\begin{array}{c}-0.00826 \\
(0.200)\end{array}$ & $\begin{array}{l}-0.0173 \\
(0.0289)\end{array}$ & $\begin{array}{l}-0.0123 \\
(0.0295)\end{array}$ \\
\hline Constant & $\begin{array}{l}-13.69 \\
(12.04)\end{array}$ & $\begin{array}{c}2.884 \\
(6.602)\end{array}$ & $\begin{array}{c}-2.394 \\
(9.782)\end{array}$ \\
\hline $\begin{array}{l}\text { R-squared } \\
\text { F-statistics } \\
\text { LM test } \\
\text { Hausman test } \\
\text { Country FE } \\
\text { Year FE } \\
\text { Country RE } \\
\text { Year RE }\end{array}$ & $\begin{array}{l}0.282 \\
14.80^{* * * *}\end{array}$ & $\begin{array}{l}0.504 \\
36.55^{* * *} \\
161.12^{* * *} \\
\text { YES } \\
\text { YES }\end{array}$ & $\begin{array}{l}0.455 \\
3962.15^{* * *}\end{array}$ \\
\hline \multicolumn{4}{|c|}{$\begin{array}{l}\text { Notes: Robust standard errors in brackets. } * * *, * * \text { and } * \text { denotes significance at } 1 \%, 5 \% \text {, and } \\
10 \%\end{array}$} \\
\hline \multicolumn{4}{|c|}{ Table A2. Diagnostic Test on Fixed Effect Model } \\
\hline Test & Heteroscedasticity & Serial Correlation & Cross-sectional dependence \\
\hline Modified Wald test & $813.55 * * *$ & & \\
\hline Wooldridge test & & $208.998 * * *$ & \\
\hline Pasaran CD test & & & $21.770 * * * *$ \\
\hline
\end{tabular}


Table A3. Correlation Matrix of Basic Model

\begin{tabular}{lccccccr}
\hline & $(1)$ & $(2)$ & $(3)$ & $(4)$ & $(5)$ & (6) & (7) \\
\hline lnrgdp-o (1) & 1.0000 & & & & & & \\
Lnrgdp-d (2) & 0.0644 & 1.0000 & & & & & \\
lndist (3) & 0.0915 & 0.0000 & 1.0000 & & & & \\
lnreer (4) & 0.1076 & -0.2676 & -0.0452 & 1.0000 & & & \\
lntc (5) & 0.1101 & 0.5961 & 0.7575 & -0.2998 & 1.0000 & & \\
lncapinvest (6) & 0.0386 & 0.6776 & 0.0000 & -0.0314 & 0.3559 & 1.0000 & \\
lnlinder1 (7) & -0.2549 & 0.0523 & -0.0196 & 0.1230 & -0.0019 & 0.0350 & 1 \\
\hline
\end{tabular}

Table A4. Correlation Matrix of Economic Factors

\begin{tabular}{lcccccc}
\hline & $(1)$ & $(2)$ & $(3)$ & $(4)$ & $(5)$ & $(6)$ \\
\hline lntrus (1) & 1.0000 & & & & & \\
lntrorigin (2) & 0.0801 & 1.0000 & & & & \\
lnrp (3) & 0.1804 & 0.7324 & 1.0000 & & & \\
lnspcan (4) & 0.1535 & 0.0482 & 0.1396 & 1.0000 & & \\
lnspmex (5) & 0.1028 & 0.0370 & 0.0592 & 0.4899 & 1.0000 & \\
lncapinvest (6) & 0.0954 & 0.0352 & 0.0503 & 0.2905 & 0.7165 & 1.0000 \\
\hline
\end{tabular}

Table A5. Correlation Matrix of Demographic Factors

\begin{tabular}{lccccc}
\hline & $(1)$ & $(2)$ & $(3)$ & $(4)$ & (5) \\
\hline lnpop (1) & 1.0000 & & & & \\
lnAge1 (2) & 0.0535 & 1.0000 & & & \\
lnAge2 (3) & -0.3382 & 0.0775 & 1.0000 & & \\
lnGender (4) & 0.3791 & 0.0225 & -0.5767 & 1.0000 & \\
lnUrban (5) & -0.4780 & 0.0554 & 0.4417 & -0.7366 & 1.0000 \\
\hline
\end{tabular}

Table A6. Correlation Matrix of Incidental Factors and Government Policies

\begin{tabular}{lccccc}
\hline & $(1)$ & $(2)$ & $(3)$ & $(4)$ & $(5)$ \\
\hline Ecorec (1) & 1.0000 & & & & \\
lncasorig (2) & 0.0096 & 1.0000 & & & \\
lncasus (3) & -0.1079 & 0.0180 & 1.0000 & & \\
VWP (4) & 0.0028 & -0.1923 & 0.0072 & 1.0000 & \\
Chusmou (5) & 0.0475 & 0.2479 & -0.0212 & -0.1120 & 1.0000 \\
\hline
\end{tabular}


Table A7. Correlation Matrix of Cultural factors

\begin{tabular}{lccccc}
\hline & $(1)$ & $(2)$ & $(3)$ & $(4)$ & $(5)$ \\
\hline Rchr (1) & 1.0000 & & & & \\
Roth (2) & -1.0000 & 1.0000 & & & \\
Leng (3) & 0.2548 & -0.2548 & 1.0000 & & \\
Lspan (4) & 0.3162 & 0.3162 & -0.2820 & 1.0000 & \\
Loth (5) & -0.4781 & 0.4781 & -0.5330 & -0.6614 & 1.0000 \\
\hline
\end{tabular}

Table A8. Correlation Matrix of Governance Indicators

\begin{tabular}{lcccccccc}
\hline & $(1)$ & $(2)$ & $(3)$ & $(4)$ & $(5)$ & $(6)$ & $(7)$ & $(8)$ \\
\hline lneddex (1) & 1.0000 & & & & & & & \\
lnffm (2) & 0.4098 & 1.0000 & & & & & & \\
lnauto (3) & -0.8933 & 0.2091 & 1.0000 & & & & & \\
lndemo (4) & 0.3111 & 0.2044 & -0.9983 & 1.0000 & & & & \\
lnefdex (5) & 0.6641 & 0.3462 & -0.6540 & 0.6416 & 1.0000 & & & \\
lnpsav (6) & -0.0343 & -0.0195 & -0.0497 & 0.0023 & -0.0278 & 1.0000 & & \\
lngoveff (7) & -0.2217 & -0.0531 & -0.0100 & 0.0853 & -0.0020 & 0.2913 & 1.0000 & \\
lnrolaw (8) & 0.1886 & 0.0365 & 0.0928 & -0.0732 & 0.0244 & -0.0958 & -0.6033 & 1.0000 \\
\hline
\end{tabular}




\section{CHAPTER 5. CONCLUSIONS}

The United States tourism industry is a significant player in global tourism. Like the latter, growth in the former has generally been trending upwards over the years and is projected to continue in short to medium term. The U.S. tourism industry is a leading exporter of global tourism and a leading recipient of global tourism revenues. It accounts for 31 percent of all U.S service exports, the $7^{\text {th }}$ largest employer in the private sector in the United States and generating about $\$ 990.3$ billion aggregate direct spending in 2016 into the U.S economy. Given the growing importance and competitiveness of global tourism, it is imperative to understand how this emerging tourism impacts the economies of nations. The three essays investigate the nature of the relationship between tourism and economic growth in the United States.

The first essay investigated the causal relationship between tourism and economic growth in the United States. The results provide support for the economic-driven tourism growth hypothesis in the United States. Real GDP Granger causes tourist arrivals in the United States in the long-run but not in the short-run. Real effective exchange rate Granger cause tourist arrivals in both short and long-runs. The results from the impulse response function indicate that a shock to GDP generates a positive and significant effect on tourist flow to the United States that persist in the long-run, whereas shocks to exchange rates have a significant effect that lasts for six months. From the generalized variance decomposition analysis, exchange rate changes account for a larger share of the forecast error variance in tourist arrivals than real GDP in the short-run. This paper could be improved by using a larger data set accounting for seasonality given that tourism is a seasonal activity.

The second essay examined the tourism-economic growth nexus at the disaggregated level. It investigated the relationship between economic growth and six tourism-related industries - 
accommodation, air transportation, shopping, food and beverage, other transportation, and recreation and entertainment. The results found no long-run relationship between tourism subindustries and economic growth except for lodging, and food and beverage sub-industries. In the short-run, however, there was causality running from economic growth to each of the tourism subindustries. In addition, the results found the causal relationship among the tourism sub-industries. Causality runs from predominantly industries providing local offering - food, entertainment, and shopping, to those delivering cross destination goods and services.

The third essay employed the Poisson Pseudo Maximum Likelihood and the systems GMM within the gravity model framework to examine the push and pull factors for tourism demand in the United States. The results indicate that income in source countries and distance between the source and destination countries are significant determinants of tourism demand. Also, other economic factors - real effective exchange rate, the relative cost of living, travel cost, trade openness, and capital investment, cultural factors - language and religion, significantly influence tourism demand. Furthermore, democratic factor like urbanization, government policies like the visa waiver program and the China-U.S. memorandum of understanding are significant drivers of inbound tourism in the United States. The results also provide evidence of the Linder hypothesis in the tourism literature in the United States. The results from the dynamic model indicate that habit persistence and/or word-of-mouth account for a great percentage of tourism demand in the United States.

Even though the U.S. is a leading exporter of tourism, it is also a significant importer of global tourism. While few studies have examined the determinants of inbound tourism to the United States, very little to no studies, have investigated the factors driving outbound tourism from the United States. Future research may explore the determinants of outbound tourism from the 
U.S to mirror that of inbound tourism. Furthermore, many studies have explored the key determinants of tourism demand, focusing on the aggregate flow of tourists (arrivals) and the receipts (revenues) generated, using single equation approach. As helpful this approach has been over the period in modeling and forecasting tourism demand, it suffers from some limitations. It is unable to analyze the interdependence of budget allocations to different goods and services (Eadington and Redman, 1991). Further research should investigate the budget allocations decisions on tourism goods and services at specific destinations using the systems of equations. 